\title{
Exosomes in cancer: small vesicular transporters for cancer progression and metastasis, biomarkers in cancer therapeutics
}

\author{
Atefe Abak ${ }^{\text {Corresp., }}{ }^{1}$, Alireza Abhari ${ }^{2}$, Sevda Rahimzadeh ${ }^{2}$ \\ 1 Department of Medical Genetics, Faculty of Medicine, Tabriz University of Medical Sciences, Tabriz, Iran \\ 2 Department of Biochemistry and Clinical Laboratory, Faculty of Medicine, Tabriz University of Medical Sciences, Tabriz, Iran \\ Corresponding Author: Atefe Abak \\ Email address: atefeh.abak@gmail.com
}

Cancer progression is a polygenic procedure in which the exosomes can function as substantial roles. Exosomes are tiny, phospholipid bilayer membrane nanovesicles of endocytic derivation with a diameter of 40-100 nm. These nanovesicles can transport bioactive molecules containing mRNAs, proteins, DNA fragments, and non-coding RNAs from a donor cell to recipient cells, and cause the alteration in genetic and epigenetic factors and reprogramming of the target cells. Many diverse cell types such as mesenchymal cells, immune cells, and cancer cells can induce a release of exosomes. Increasing evidence illustrated that the exosomes derived from tumor cells might trigger the tumor initiation, tumor cell growth and progression, metastasis, and drug resistance. The secreted nanovesicles of exosomes can play significant roles in cells communicate via shuttling the nucleic acid molecules and proteins to target cells and tissues. In this review, we discussed multiple mechanisms related to biogenesis, load, and shuttle of the exosomes. Also, we illustrated the diverse roles of exosomes in several types of human cancer development, tumor immunology, angiogenesis, and metastasis. The exosomes may act as the promising biomarkers for the prognosis of various types of cancers which suggested a new pathway for anti-tumor therapeutic of these nanovesicles and promoted exosome-based cancer for clinical diagnostic and remedial procedures. 
Exosomes in cancer: small vesicular transporters for cancer progression and 1 $\begin{array}{ll}\text { metastasis, biomarkers in cancer therapeutics } & 2\end{array}$

$\begin{array}{lr}\text { Atefe Abak }{ }^{1} \text {, Alireza Abhari }{ }^{2}, \text { Sevda Rahimzadeh }{ }^{2} & 3 \\ \end{array}$

${ }^{1}$ Department of Medical Genetics, Faculty of Medicine, Tabriz University of Medical Sciences, Tabriz, Iran. 5

${ }^{2}$ Department of Biochemistry and Clinical Laboratory, Faculty of Medicine, Tabriz University of Medical 6

$\begin{array}{ll}\text { Sciences, Tabriz, Iran. } & 7\end{array}$

\begin{tabular}{rr} 
& 8 \\
\hline
\end{tabular}

$\begin{array}{lr}\text { Corresponding Author: } & 9\end{array}$

$\begin{array}{lr}\text { Atefe } \mathrm{Abak}^{1} & 10\end{array}$

11
10

Email Address: Atefeh.abak@gmail.com, abaka@tbzmed.ac.ir 12

ABSTRACT. Cancer progression is a polygenic procedure in which the exosomes can 14 function as substantial roles. Exosomes are tiny, phospholipid bilayer membrane 15 nanovesicles of endocytic derivation with a diameter of 40-100 nm. These nanovesicles can 16 transport bioactive molecules containing mRNAs, proteins, DNA fragments, and non-coding 17 RNAs from a donor cell to recipient cells, and cause the alteration in genetic and epigenetic 18 factors and reprogramming of the target cells. Many diverse cell types such as 19 mesenchymal cells, immune cells, and cancer cells can induce a release of exosomes. 20 Increasing evidence illustrated that the exosomes derived from tumor cells might trigger 21 the tumor initiation, tumor cell growth and progression, metastasis, and drug resistance. 22 The secreted nanovesicles of exosomes can play significant roles in cells communicate via 23 shuttling the nucleic acid molecules and proteins to target cells and tissues. 24 In this review, we discussed multiple mechanisms related to biogenesis, load, and shuttle of 25 the exosomes. Also, we illustrated the diverse roles of exosomes in several types of human 26 cancer development, tumor immunology, angiogenesis, and metastasis. The exosomes may 27 act as the promising biomarkers for the prognosis of various types of cancers which 28 suggested a new pathway for anti-tumor therapeutic of these nanovesicles and promoted 29 exosome-based cancer for clinical diagnostic and remedial procedures. 30 
The solid tumors are complicated structures that including the surrounding tumor stroma $\quad 34$ and cancer cells, which composed of endothelial cells, fibroblasts, and immune cells (Sund 35 \& Kalluri 2009). The surrounding cells are permanently extracting factors that alter the 36 tumor microenvironment (TME) directly or indirectly (Dvorak et al. 2011). A persistent 37 cross-talk among tumor cells and the distant tumor microenvironment have applied as the 38 pivotal tumor growth, and significant targets in antitumoral intervention, and systemic 39 diffusion (Kalluri \& Zeisberg 2006; Swartz et al. 2012). Extracellular vesicles (EVs) have 40 appeared as long-distance communicators; their outcomes in primary tumors can display as systemic effects and contribute to procedures within the circulation by many various kinds of cells. The exosomes pretense a special class of EVs, which released via various kinds of cells (Desrochers et al. 2016; Kowal et al. 2014; Mathivanan et al. 2010). Newly evidence represents that the release of exosomes has been detected to play a considerable role between human tumor cells and systemic cell-to-cell relevance in cancers. The exosomes, initially defined through several common traits in reticulocytes three decades ago, containing morphology (a classic "dish" or "cup" formed in transfer electron 48 microscopy (SEM)), density (1.13-1.19 g/ml), size (30-100 $\mathrm{nm}$ in diameter), and 49 determined increased protein markers (TSG101, HSP70, and tetraspanins) (Harding et al. 50 2013). Recent publications illustrated that exosomes are small membrane nanovesicles 51 shaped in multivesicular bodies of endocytic derivation with a diameter of 40-100 nm. 52 Exosomes were primarily considered as the trash bags for elimination of abandoned 53 membrane segments and unwanted molecular fragments from cells, besides the critical 54 task of exosomes in stimulation of immune response is identified as their effect on antigen $\quad 55$ presentation in the mid-1990s (Raposo et al. 1996). Interestingly, the scholars detected 56 that noncoding RNAs (miRNAs), messenger RNAs (mRNAs), proteins and DNA fragments 57 could be burdened as "goods" in extracellular vesicles (EVs) (Balaj et al. 2011). Likewise 58 the exosomes as a nanovesicles were detected to function as "communication shuttles" 59 from a donator cells to recipient cells, that could able to re-encode genes of receiver cells, $\quad 60$ reprogramming of the tumor microenvironment and recruitment to shape a pro- 61 tumorigenic soil, and play a considerable act in the progression, invasion, metastasis, and 
become insensitive to a drug of cancer (Azmi et al. 2013; Balaj et al. 2011; Valadi et al. 63 2007).

Here we reviewed a new science concerning the function of exosomes as a shuttle in 65 tumorigenesis, emphasizing their biogenesis, component, significant affection, and then 66 considering the potential of exosomes as a novel biomarkers for clinical remedial target 67 diagnosis and prognosis.

\section{SURVEY METHODOLOGY}

PubMed was mostly utilized to search for relevant articles published utilizing the keyword 71 "exosome", "cancer" and "therapy." Afterward, screened articles were utilized as references 72 for this review. Additional keywords, such as "microenvironment," "nanovesicles" and 73 "tumor," were also utilized.

\section{Exosomes Biogenesis, Release, and Uptake}

Contrary to the larger microvesicles (MVs), that straightly shed from the cell membrane, 77 the exosomes forming is a specific process that contains four steps: beginning, endocytosis, 78 multivesicular bodies (MVBs) creation, and finally the exosome secretion (Théry et al. 79 2002). Exosomes primarily can shape through the ceramide-induced procedures of inside 80 budding from the late endosome restricted membranes (Trajkovic et al. 2008). The 81 encapsulation of RNA molecules and functional proteins occur through this process. The 82 Multivesicular bodies (MVBs) within the endocytic systems shaped via the budding of an 83 endosome limited membrane into the extracellular milieu of the section by the junction and 84 merge of the MVBs with the cell membrane. The MVBs are either classified as the 85 destroying of cargo in the lysosome or leading to secretion within the extracellular space as 86 exosomes after vesicular cumulation (Février \& Raposo 2004; Trams et al. 1981). The 87 procedures based on the classified of exosomal cargo within the intraluminal vesicles 88 (ILVs) is still not completely understood. Although it has been offered to characterize the 89 exosomes formation and releasing by both endosomal tethering complexes necessitated for 90 
transport (ESCRT)-dependent and independent symptoms, however, alternative ways may 91 also exist (Trajkovic et al. 2008). The ESCRT pathway discerns ubiquitination of membrane 92 proteins and promotes their internalization within the multivesicular endosome (Wollert \& 93 Hurley 2010). The mechanism for the microvesicles formation has been illustrated to 94 regulate through the syndecan heparan sulfate proteoglycans and their cytoplasmic 95 adaptor syntenin (Baietti et al. 2012). The MVB trafficking and the secretion procedure of 96 exosomes may be performed through the outside of exosomes and the microvesicles 97 budding procedure or through multiple compositions of the endocytic machinery, 98 containing the members of the Rab guanosine triphosphatase (GTPase) family (Rab11, Rab 99 27a, Rab 27b, Rab 35), elevated expression of heparanase, SNARES (soluble NSF 100 attachment receptor), and cytoskeleton regulatory proteins (Azmi et al. 2013; Beach et al. 101 2014; Ostrowski et al. 2010; Pant et al. 2012). A promoted dissemination of exosomes is 102 critically was detected to be triggered via multiple kinds of stress, including alters in PH 103 membrane, oxidative stress, shear stress, hypoxia, thermal alters, and radiation, besides 104 through formation of ceramide, stimulation of sphingomyelinase and following the p53- 105 adjusted protein tumor-suppressor-activated pathway 6 (TSAP6) (Andaloussi et al. 2013; 106 Azmi et al. 2013; Hannafon \& Ding 2013; Joanne et al. 2005; Kucharzewska \& Belting 2013; 107 Lespagnol et al. 2008; Parolini et al. 2009; Yu et al. 2006). Exosomes shuttle information to 108 the recipient cells via three major pathways: (1) interaction between receptor-ligand; (2) 109 straight merge with cell membrane; (3) endocytosis through phagocytosis (Figure 1). Also, 110 there are multiple proteins that can function as specific receptors to activate the uptake of 111 the exosome, containing ICAM-1 for APCs, and Tim 1/4 for B-cells (Miyanishi et al. 2007; 112 Segura et al. 2005). 113

Exosomes are commonly cup-shaped extracellular small nanovesicles ranging in size from 116 30 to $100 \mathrm{~nm}$ diameter, consist of a phospholipid bilayer comprising membrane proteins 117 that encircles a lumen containing an extensive range of biomolecules including 118 carbohydrates, lipids, small fragments of DNA, mRNAs, proteins, and miRNAs inward to 119 
keep them from destruction (De Veirman et al. 2016; Hwang 2013; Raimondo et al. 2011; 120 Vlassov et al. 2012; Wang et al. 2016).

4.1. Protein Composition of Exosomes. Exosomes from several kinds of cells include a 122 core set of similar proteins upon 4600 various proteins have been related to these 123 microvesicles, containing proteins from the phospholipid bilayer, endoplasmic reticulum, 124 cytosol, and Golgi apparatus such as the heat shock proteins (HSP60, HSP70, and HSP90), 125 the tetraspanin family (CD63, CD81, CD9, and CD82), cytoskeletal proteins (tubulin, 126 moesin, actin, and syntenin), proteins involved in ESCRT complex (Alix, TSG101), 127 phospholipases and lipid-related proteins (Bang \& Thum 2012; Hannafon \& Ding 2013; 128 Harshman et al. 2013; Mathivanan et al. 2010; Taylor \& Gercel-Taylor 2011; Vlassov et al. 129 2012).

4.2. Lipid Composition of Exosomes. Exosomes are containing a lipid bilayer including 131 polyglycerophospholipids, sphingolipids (ceramide, sphingomyelin), raft-associated lipids 132 (cholesterol), glycerophospholipids (phosphatidylethanolamine, phosphatidylserine, 133 phosphatidylinositol, phosphatidylcholine), and phospholipids. Also, the lipid composition 134 in exosomes varies significantly from that of the original cells (Record et al. 2014).

4.3. Nucleic Acid Composition of Exosomes. The double-stranded deoxyribonucleic acids 136 exist in these microvesicles derived from tumoral cells and cause the aberrant regulation of 137 the derived cells (Silva et al. 2012). The other nucleic acids that carry with exosomes 138 contain of mitochondrial DNA (mtDNA), messenger RNAs (mRNAs), microRNAs (miRNAs), 139 long noncoding RNAs (lnc RNA), small-nuclear RNAs (snRNAs), small nucleolar RNAs 140 (snoRNAs), piwi-RNAs (pi-RNAs), transfer RNAs (tRNAs), and ribosomal RNAs (rRNAs). 141 Exosomal-containing RNA can transfer among a variety of cells and therefore is termed 142 "exosomal shuttle RNA" (esRNA). Recently 764 miRNAs and 1639 mRNAs have been 143 recognized in these nanovesicles from tissues of various species via a broad range of 144 researches (Gajos-Michniewicz et al. 2014). 145 The composition of exosomes differs between various pathological and physiological status 146 and originated cells. Also, the contents of these nanovesicles can discern from the derived 147 cells because of the optional categorized of the cargo within exosomes. 
As a communicator, exosomes can directly shuttle the bioactive molecules among multiple 150 kinds of recipient cells, with results in targeted cellular phenotyping, contained messenger151 RNA (mRNA) and microRNA (miRNA) dependent on the shuttle of genetics, and also 152 epigenetic information and lipid trafficking among cells (Azmi et al. 2013; Xiang et al. 153 2009). The existence of exosomes in the circulating body fluids reveals their role in various 154 pathological situations, the instance of infection disease, cardiovascular disease, and progression of neurodegenerative disease (Bang \& Thum 2012; Fleming et al. 2014). The 155 more substantial role of exosomes has been figured out in cancer which leads to tumor 156 growth, angiogenesis, escaping from the immune response, causing tumor cell migration, stimulating normal cells to an invasion, and leading to metastatic colonization into distal tissues (Azmi et al. 2013).

\section{Methods for the Isolation and Analysis of Biomarkers from Exosomes in Cancer}

Recently, different methods are available for the isolation and discern of exosomes from assay (ELISA), which can identify RNA and protein of exosomes, also ultracentrifugation, commercial kits, magnetic activated cell sorting (MACS) can utilize as another method. To date, the international society for extracellular vesicles (ISEV) can apply for the detection of extracellular vesicles and their functions. Also, western blot and flow cytometry (FCM) commonly utilizes for recognizing of exosomes through discovering particular tetraspanins (for example CD9, CD63, and HSP70). Further, the transmission electron microscopy (TEM) isolation of exosomes contains ultracentrifugation, which is often in combination with 175 sucrose density gradients or sucrose cushions to float the relatively low-density exosomes. 176 The ultracentrifugation procedure has multiple disadvantages: The manner is extremely 
labor-intensive and time-consuming; due to the restrictions of the design of ultracentrifuge 178 rotors one cannot evaluate more than six specimens at a time; the procedure needs a major 179 amount of raw materials; exosome productions are usually low; and vast training of staff is 180 required (Théry et al. 2006; Zeringer et al. 2015). Isolation of exosomes based on size, by 181 the prosperous isolation of exosomes through applying the ultrafiltration methods which 182 are less time-consuming than ultracentrifugation and do not need the usage of the 183 particular tool (Cheruvanky et al. 2007). HPLC (high-performance liquid chromatography)- 184 based protocols could effectively permit the preparation of extremely pure exosomes. 185 however, these methods need appropriative material and are not negligible to scale-up (Lai 186 et al. 2010). Besides, the intricacy is that both body fluids and cell-culture media include an 187 extensive amount of nanoparticles in the identical size range as exosomes. For instance, 188 many miRNAs are included within extracellular protein complexes rather than exosomes 189 (Wang et al. 2010). In addition, volume-excluding polymers such as polyethylene glycols 190 (PEGs) could be used to precipitate exosomes from empirical specimens. The precipitate 191 can be separated applying either low-speed centrifugation or filtration. System Biosciences 192 presents an appropriative reagent called ExoQuick, which can be added to conditioned cell 193 media, urine or serum, which precipitates these nanovesicles (Adams 1973; Lewis \& 194 Metcalf 1988; Yamamoto et al. 1970). In principle, a preferable resource for special 195 purification of exosomes should be affinity isolation with antibodies to Alix, annexin, CD63, 196 CD81, CD82, CD9, EpCAM, and Rab5. These antibodies could be collected on multiple 197 media, containing microfluidic devices, plates, magnetic beads and chromatography 198 matrices(Chen et al. 2010; Théry et al. 2006).

7.1. Role of Exosomes in Cancerogenesis. As mentioned earlier, the exosomes revealed 202 important roles in cancer progression. The exosomes released by human cancer cells are 203 known as tumor-derived (TD) exosomes. The TD exosomes through autocrine signals can 204 modulate the local growth progression of human cancer cells. The exosomal autocrine 205 signaling pathway is related to kinds of cells and cellular traits, for instance, exosomes 206 
separated from gastric cancer cells with high CD97 (epidermal growth factor seven207 transmembrane subfamily) expression enhanced cancer cell proliferation and invasion via exosome-mediated MAPK signaling pathway, and exosomal miRNAs may be contributing to induction of the CD97-associated pathway (Li et al. 2015). A mutant epidermal growth factor receptor (EGFRVIII), exists on the membrane of these nanovesicles originated from glioblastoma cells, can trigger cells loss of this mutant form. The integration of EGFRVIII within these cells caused by promotion of anti-apoptotic procedures and an augment in capacity for anchorage-independent growth (Al-Nedawi et al. 2008). On the other hand, the exosomes originated from pancreatic cancer cells enhance Bax expression, however, reduce Bcl-2 expression, cause the leading to cancer cells of the mitochondrial apoptotic pathway (Ristorcelli et al. 2008). This process illustrated that TD exosomes might act pivotal anti-cancer role through triggering apoptosis in several tumors. Accordingly, the determined or beneficial TD exosomes in vivo to their own survival relies on the cellular traits and kinds of the cells, which more research needs to be clarified. Moreover, the bone marrow mesenchymal stromal cells (BM-MSCs)-derived exosomes can support the multiple tumor cell expansion and development in various human cancer cells (Figure 2). endothelial cell proliferation, migration, and budding (Dvorak 1986; Nazarenko et al. 
establishing a niche in the lung microenvironment of SCID mice through the elevate 237 expression of MMP2, MMP9, and VEGFR1 (Grange et al. 2011). In addition, the exosomes 238 originated from hypoxic brain tumor glioblastoma multiform cells were increased with IL-8 239 and PDGF as angiogenic stimulatory molecules (Kucharzewska et al. 2013). 240

7.3. Role of Exosomes in Tumor Metastasis. A major pathway in the metastatic cascade 241 is tumor cell invasion and migration, missing the epithelial traits towards a more 242 mesenchymal phenotype and the ability of the cell to attain a motile phenotype via changes 243 in the cell to matrix interaction, disseminating tumor cells extravasate into remote sites 244 and finally colonize secondary tissues and organs. There is an emerging report that shows tumor-derived exosomes are accomplished by tumor invasion and metastasis through regulating stromal cells, creating a pre-metastatic niche (Figure 3), remodeling the 245 246 extracellular matrix (ECM) and inducing angiogenesis (Alderton 2012; Jung et al. 2009). Metastatic tumor cells dissemination enhanced level of miRNA by tumor-suppressor mechanism, that can indicate another procedure for the function of these nanovesicles in metastasis (Ostenfeld et al. 2014). The recent study illustrated that the exosomal proteins originated from tumor hypoxia of prostate cancer cells are associated with the process of adherens junctions in epithelial cells and cytoskeleton remodeling, including the enhanced metastasis and invasiveness in prostate cancer cells, is modulated through exosomes (Ramteke et al. 2015). Also, by recent investigate gastrointestinal stromal tumor cells (GISTs) secrete exosomes including protein tyrosine kinase to transform progenitor cellderived smooth muscle cells to a premetastatic phenotype (Atay et al. 2014). Another report indicated that the Colorectal cancer cells with high invasive potential were detected to be significantly dependent on the concentration of exosomes including the signaling competent epidermal growth factor receptor (EGFR) ligand, inferring that exosome247 mediated ligand shuttle causes cancer invasiveness and metastasis (Higginbotham et al. 259 260 2011). Exosome-modulated transferring of microRNA-221/222 from mesenchymal stem tumoral cells (Wang et al. 2014b).

7.4. Role of Exosomes in Tumor Immune Escape. The current researches represented 265 that tumor-derived microvesicles may function as immunosuppressive effects. Exosome- 
mediated communication among cancer cells and the immune system is triggered 267 recruiting pro-cancerogenic immune cells (Figure 4). Also, tumor-derived exosomes are 268 being utilized as an effective source of tumor antigen to induce dendritic cells (DCS), 269 causing a shuttle of tumor antigens to DCs and including CD8+ T cell-related anti-tumor 270 outcomes. The exosomal tumor-carried TGF- $\beta 1$ deviated IL-2 modulates in favor of 271 regulatory T cells and away from cytotoxic cells (Bu et al. 2011; Clayton et al. 2007). Also, 272 tumor-derived exosomes can activate myeloid-derived suppressor cells (MDSC). The 273 MDSCs by inhibiting the T cell reaction can apply immunosuppressive functions in cancer. 274 tumor-derived microvesicles from several tumor cell lines modulate synthesis of 275 interleukin-6 (IL-6) in MDSCs via the activation of Toll-like receptor 2 through the 276 membrane-associated heat shock protein 72 (HSP 72). Making of IL-6 outcomes in an 277 autocrine phosphorylation of stat3 in MDSCs can enhance their immunosuppressive 278 function (Chalmin et al. 2010; Nagaraj \& Gabrilovich 2012). The miRNA shuttled via cancer 279 cell-derived exosomes may function as ligands through attaching to the Toll-like receptors and activate the inflammation. Indeed, it was cleared that oncogenic miR-21 and miR-29a released from the exosomes derived from highly metastatic lung carcinoma cells can bind to the human and murine TLRs (Fabbri et al. 2012).

7.5. Role of Exosomes in Mediating Insensitivity to a Drug in Cancer. Exosomes via 284 several mechanisms may play pivotal role in the progression of therapy resistance in 285 cancer cells. Tumor-derived microvesicles can shuttle multi-drug resistance (MDR)286 associated miRNAs and proteins to target cells. These illustrated that several major classes 287 of anticancer drugs and their metabolites can be encapsulated and exported through 288 exosomes outside of the cells, and shedding of these extracellular vesicles (EVs) is 289 intimately associated with insensitivity to a drug (Figure 5) in various human cancer cells 290 (Corcoran et al. 2012; Safaei et al. 2005; Shedden et al. 2003; Wei et al. 2014). Recently, 291 emerging evidence illustrated that miR-21 was shuttled from cancer-associated adipocytes 292 of fibroblasts to the various tumor cells, where it can inhibit ovarian cancer apoptosis and 293 induce the Paclitaxel resistance through binding to its new direct target, apoptotic protease 294 activating factor-1 (APAF1) (Yeung et al. 2016). Besides, there is plenty of interest in 295 insensitivity to a drug through exosome-mediated shuttle of miRNAs. Several studies 
suggested that breast cancer cells resistant to various drugs (Docetaxel-Adriamycin297 Tamoxifen) may shuttle the resistance to sensitive cells in part via exosomal miRNA 298 exchange (Chen et al. 2014). Moreover, PTEN is reduced in exosomes therefore applying 299 biological acts in target cells. The loss of function of PTEN enhances resistance to sensitivity 300 and chemotherapeutic of mTOR, which inhibits in breast cancer cells and, afterwards, 301 PTEN exosomal shuttle, could be drew out as a shuttle mechanism or drug resistance changes (Steelman et al. 2008). Besides exosomes through regulating their binding to 302 tumor cells may counteract the efficacy of antibody drugs. The exosomes-originated lymphoma carry CD20 can bind to the anti CD-20 antibody therapeutics and induce the preserving of target cells from antibody attack (Aung et al. 2011). Thus, the exosomesderived cancer cells can be utilized as a procedure of cancer chemotherapy resistance of special cancer cells to special drugs.

7.6. Use of Exosomes as a Tumor Diagnostics and Biomarkers. The indicating of 309 significant functional roles of exosomes in approximately all aspects of tumor cells was 310 preparing the opportunities for enhancement of these nanovesicles as a considerable 311 diagnostic biomarkers and remedial targets. The exosomes derived-human tumor cells are enriched with mRNA, proteins, and miRNA which are more plentiful in tumor than in healthy noncancerous cells (Roma-Rodrigues et al. 2014). One of the principal beneficiaries 314 of the utilize of these nanovesicles as a valuable biomarkers is the feasibility of a fast pathology detection by minimally invasive procedures (Li \& Bahassi 2013). The existence 316 of exosomes in the blood circulatory system and shedding these nanovesicles into 317 biological fluids such as urine, saliva, and ascites of exosomes containing biomarkers in 318 several subtypes of human tumor cells can be obtained the minimally invasive "liquid 319 biopsies" (for example blood collection) for clinical use (Zhang \& Grizzle 2014). Also these microvesicles are really resistant under variant storage situations containing short-term storage at $4^{\circ} \mathrm{C}$ for 96 hours or long-term storage at $-70^{\circ} \mathrm{C}$ (Taylor \& Gercel-Taylor 2008). biomarkers for early diagnostics of cancer cells and personalized cancer therapies. Several in vitro studies suggested that exosomes derived human tumor cells can be utilized as a 325 remarkable biomarker to diagnose cancer cells through applying the methods of 326 
proteomics and transcriptomics (Aushev et al. 2013; Dijkstra et al. 2014). Also, the 327 enhanced levels of exosomes in blood plasma specimens of colon carcinoma patients was 328 considerably linked to the weakly differentiated tumor cells and the declined entirely 329 survival (Silva et al. 2012). Another study illustrated that exosomal EDIL3 and fibronectin 330 in circulating EVs can utilize as pivotal biomarkers of early stage breast cancer through 331 applying ELISA methods (Moon et al. 2016). Recent report showed that PCA3 and 332 TMPRSS2:ERG, two established proteins exist in urinary exosomes from prostate cancer 333 proteins which are detected as a potential biomarkers through label-free liquid 334 chromatography-tandem mass spectrometry (LC-MS/MS) (Nilsson et al. 2009). These 335 finding show that the bodily fluids originated exosomes may be an important noninvasive 336 marker for the early tumor detection.

7.7. Use of Exosomes as a Cancer Therapeutic. Emerging reports indicates that various 338 clinical researches illustrated the role of exosomes as cancer remedies, and a few main 339 adverse effects were identified for applying of these nanovesicles in cancer therapy. Figure 6 indicates the remedies that were proposed for therapy of cancers based on exosomes characteristics.

1) Trough secretion of exosomes, tumoral cells trigger the alteration of the local and 343 systemic tumor environment to induce tumor growth promotion, metastasis and insensitivity to drugs. Thus, either the destruction of exosome-dissemination pathway through tumor cells or the removal of these nanovesicles from the blood circulatory system may create an effective method for cancer therapy. The Tinzaparin (a low-molecularweight heparin) can trigger tissue factor pathway inhibitor (TFPI) secretion from cancer cells, and also the recombinant TFPI induce suppression of tumor-derived exosomes causing migration of tumor cells (Gamperl et al. 2016). Lately for the elimination of extracellular vesicles (EVs) from the blood circulatory system, a therapeutic hemofiltration process which is called ADAPT ${ }^{\mathrm{TM}}$ (adaptive dialysis-like affinity platform technology) is applied. Whenever the patient's blood plasma samples transfer via ADAPT ${ }^{\mathrm{TM}}$ system, plasma specimens factors by the porous fibers are interacted with the immobilized affinity agents to that target molecules are particularly absorbed while unbound serum factors and blood cells can pass through this system (Logozzi et al. 2009). 
2) As a delivery system, exosomes are considerably utilized as vehicles loaded with 357 multiple anticancer drugs, siRNAs, and miRNAs for several cancer therapeutic cargos. The 358 lipid bilayer membrane of these nanovesicles forms a natural protective shelter, thus 359 enhances the cellular internalization of the encapsulated anti-cancer drugs. Regarding to 360 the exosomes originated from autologous cancer cells, these nanovesicles can cause 361 minimal toxicity when being shuttled into the target cells and can be less immunogenic 362 than artificial delivery vehicles. Also their naturally small size permit them to elude 363 phagocytosis through the mononuclear phagocyte system (MPS) and simplify their 364 extravasation via tumor blood vessels and their subsequent release in target cancer tissues. 365 The various researches illustrated that prosperous delivery and tumor inhibition utilizing 366 this procedure. The enhancement of colorectal and breast xenograft cancers in vivo by 367 applying the doxorubicin loaded into exosomes or using exosome-mimetic nanovesicles 368 can be suppressed. Thus, the efficacy of doxorubicin was widely promoted through 369 targeting the immature dendritic cell exosomes into cancer tissues (Jang et al. 2013; Tian et 370 al. 2014). Also the another greatly utilized antimitotic chemotherapeutic drug is Paclitaxel that can be loaded into microvesicles through sonication, and these loaded microvesicles have 50 times more cytotoxicity than free Paclitaxel for drug resistance tumor cells in vitro. 373 Besides the exosome-encapsulated paclitaxel can considerably block murine Lewis lung cancer pulmonary metastases and decline size of tumor in the mouse model (Kim et al. 375 2016).

3) Exosomes can be utilized to target special tissues or organs because of the having special cell tropism according to their traits. Applying the well-characterized exosomal membrane 378 protein (Lamp2b) for expressing the targeting peptide instantly below the signal peptide 379 sequence including the targeting peptides RVG and iRGD were prosperously inserted 380 within these nanovesicles from immature dendritic cells to target either brain or cancer 381 tissues. This method considerably promoted the cellular uptake of the nanovesicles in the 382 tissue of interest, and enhanced the specificity of the remedy, and also reduced the toxicity 383 of drugs delivered through exosomes (Jang et al. 2013; Tian et al. 2014).

4) In addition to anticancer therapeutic drugs, exosomes can likewise deliver several tumor 385 antigens, nanobodies, apoptotic-containing proteins, proteasomes, deficient or mutant anti- 
apoptosis proteins, tumor and tissue-specific peptides, transferrins, and lactoferrins 387 within tumor cells for targeting remedy (Aspe et al. 2014; Cho et al. 2005; Hall et al. 2016; Hung \& Leonard 2015; Kooijmans et al. 2016; Lai et al. 2012; Malhotra et al. 2016).

5) Also, exosomes based cell-free vaccines could indicate an alternating to dendritic cells 390 (DCs) treatment for inhibiting tumor development through the function of exosomes in the 391 immune system. So researchers detected that the nanovesicles originated from peptide392 pulsed DCs, can present antigens to $\mathrm{T}$ cells to affect their immune response. These DCoriginated exosomes include MHC-peptide complexes and co-stimulatory molecules on their membrane, that permit them to continue antigen presentation and increase immunization in mice comparing with antigen-presenting DCs (Luketic et al. 2007).

6) Moreover, miRNAs are widely detected in exosomes derived cancer cells or isolated 397 from bodily fluids that contribute to exosome-mediated cell-cell communication, and 398 induce anti-cancer traits. For instance EGFR-specific binding peptide GE11 can lead let-7acontaining exosomes to EGFR-positive cancer cells, that considerably suppressed EGFRpositive human breast tumor cell development in a heterograft mouse model (Ohno et al. 2013; Yu et al. 2015).

\section{Functions and Remedial Roles of Exosomes in different kinds of Human Cancers}

The tumor exosomes originated from the ascites of a very aggressive murine T-cell 405 lymphoma (EVs A) can effect on dendritic cells activity, thus disturbing the immune system 406 to distinguish and destroy cancer cells. Also, the expression of marker-proteins including 407 ALIX, TSG-101, CD63, CD81, and CD9 has detected in EVs A. This research illustrated that 408 EVs A triggered both humoral and cellular immune reactions. Altogether, the outcomes 409 indicated that the endosome-originated EVs secreted via an advanced-stage T-cell 410 lymphoma, stimulated a special immune reaction (Menay et al. 2017). Besides, exosomes released through chronic myelogenous leukemia (CML) cells remedied with Curcumin, which originated from the plant Curcuma longa, has the anticancer effects, include a wide 
form. The treatment of HUVECs with CML Curcu-exosomes diminished RhoB expression 415 and conversely modified endothelial cells motility. The research illustrated that the addition of CML control exosomes to HUVECs induced promotion of IL8 and VCAM1 levels, but Curcu-exosomes returned this efficacy, therefore, diminished their angiogenic properties. Overall, this research showed that besides Curcumin reduces the exosome's capability to enhance the angiogenic phenotype and to modify the endothelial barrier organization (Taverna et al. 2016). As exosomes emerge as a novel manner of intercellular communication the cargo includes through exosome is formed via somatic evolution. Regarding evaluating the effect of exosomes originated from several melanoma-related cell lines on primary CD8+ T cells act, exosomes from each cell line were different. The B16F0 exosomes dose-associated inhibited T-cell proliferation. Notwithstanding, Cloudman S91 exosomes enhanced T-cell proliferation and Melan-A exosomes load an insufficient impact on primary CD8+ T cells. Importantly, B16F0 exosomes suppressed T-cell proliferation through high-expressed of PTPN11 to tumor permeating lymphocytes would escape the extracellular control of the immune checkpoints (Wu et al. 2015). Regarding increasing evidence, extracellular vesicles (EVs) are inherently trigger intercellular relation through shuttling molecular information between cells. Therefore, the autologous cancer-cell originated EVs can be utilized as helpful carries of Paclitaxel to the prostate cancer cells, bringing the drug into the cells via an endocytic process and released into the cell cytosol leading to cell death. Most considerably, the EV-mediated delivery promoted the cytotoxic efficacy of the drug. This research suggested that the autologous EVs may be helpful for impressive transporting of chemotherapeutic agents to prostate cancer cells (Saari et al. 2015). It is noteworthy that the effective role of exosomes in relevance among cancer cells and surrounding stroma indicated that the TrkB expression in exosomes is necessitated including aggressiveness phenotype. In this report, the YKL-40 silencing contributes for reducing of TrkB, sortilin and $\mathrm{P} 75^{\mathrm{NTR}}$ expression, related to a low aggressive phenotype. The release of TrkB in exosomes from normal glioma cells was able to relieve both migration and activation of YKL-40-inactivated cells. Furthermore, TrkB-containing exosomes may be remarked as a considerable biomarker for glioblastoma diagnosis (Pinet et al. 2016). Also, MVs originated from HLSC (MV-HLSC) can suppress the growth of hepatoma tumors through shuttling genetic information that mediates with deregulated 
survival and proliferation of these cells. The antitumor effect of MV-HLSC was relevant to 446 the decreased internalization, due to the lack of CD29 on MV-fibroblast or a decreased 447 expression of antitumor miRNAs including miR-24, miR-31, miR-122, miR-125b, miR-223, 448 and miR-451. Consequently, the promoted internalization was not relevant to an increased 449 biological activity when MV-fibroblast expressing CD-29 were utilized. Hence, the various 450 composition of miRNA content between MV-HLSC and MV-fibroblast was the remarkable 451 reason for the various biological actions. Therefore, the transferring of these miRNAs 452 through MVs originated from stem cells may suppress tumor growth development and stimulate apoptosis (Fonsato et al. 2012). Another research illustrated that exosomes originated from curcumin-pretreated H1299 cells were utilized to remedy BEAS-2B cells, which triggered proliferation, colony organization, and migration of BEAS-2B cells. Curcumin is a new drug lung cancer remedy. Although, the procedure associated with the antitumor effect of curcumin is related to the promoted expression of TCF-21, triggered through a low expression of DNMT1. Therefore, mechanism of curcumin is remarkable in cancer remedy, and create the pivotal biomarkers for developing cancer diagnostic and remedial procedures (Wu et al. 2016). The new research suggested that PSC (Pancreatic Stellate Cells)-originated exosomes can trigger and elevate the proliferation and migration of PANC-1 and SUIT-2. The exosomes differentially varied expression of a plethora of genes controlling multiple cellular procedures containing cell cycle, cellular assembly and organization, DNA replication, recombinant and repair, cell death and survival, cellular development, and growth in the recipient cancer cells. Also, three chemokines, CCL20, CXCL1, and CXCL2 were detected high expressed in exosome-treated cancer cells. Besides, glypican-1, a glycoprotein discovered in PSC exosomes, as a pivotal biomarker to distinguish PDAC (Pancreatic Ductal Adenocarcinoma), and as a tumor promoter shuttled among cells through exosomes (Ali et al. 2015; Charrier et al. 2014; Farrow et al. 2003). The exosome/staphylococcal enterotoxin B is a considerable sample for apoptoimmunotherapy. The contribution of Exo and its lipid rafts in this structure assigns the feasibility of binding to pancreatic cancer cells. SEB and the characterized lipid rafts trigger the apoptotic signal both through extrinsic and mitochondria-dependent pathways. Also, the presence of tumor antigens associated with superantigen causing promotion of specific antitumor immune response (Mahmoodzadeh et al. 2014). Even more recent research 
detected that gastric cancer cells may release exosomes for transferring apoptotic signals without direct cell-cell contact to anti-cancer T cells. The Cbl-b and Cbl-c of ubiquitin ligases might have a considerable role in exosome-induced apoptosis of Jurkat $\mathrm{T}$ cells 479 through enhancing PI3K proteasome degradation, that causes inactivation of PI3K/Akt 480 signaling, therefore led to activation of caspase 3, 8, and 9. Thus, relation among exosomes and immune response is presumably to assign considerable point of view through the 482 process of tumor immune inhibition ( $Q u$ et al. 2009). Recently study illustrated that miR483 375 promoted the growth inhibitory effect, Cell progression and dissemination of colon 484 cancer through the Bcl-2 pathway. Therefore the miR-375 down-regulated in metastatic 485 CRC, and it has important role for Bcl-2 blocking, with the significant minimally invasive 486 prognostic biomarker for CRC through suppression of malignant proliferation and dissemination (Zaharie et al. 2015). Further, research reported that a HIV-Nef SMR488 originated peptide suppressed the progress of human breast tumor cells through arresting cancer cell cycle and including blockade of exosome secretion. The SMR peptide inhibited 490 the cancer cell cycle through G2/M phase boundary. While the SMR peptide and chemotherapeutic drugs were compound to remedy cancer cells, PEG-SMRwt-Clu synergically enhanced the anti-proliferative efficacies of drugs, considerably promoted the tumor cell growth suppression efficacy of drugs and inhibited exosomes secretion in breast cancer cell lines MCF-7 and MDA-MB-231 cells. Therefore the considerable usage of PEG495 SMRwt-Clu peptide is pivotal process for the prevention and therapy of human breast tumor cells (Huang et al. 2017).

\section{CONCLUSIONS}

Prosperity in remedy against intricate cancers relies on our full comprehension of the 500 complications among various components within tumors. The above studies supported the 501 viewpoint that exosomes can play a pivotal role in the growth, and promotion of cancer 502 cells via regulation of intercellular communication into the tumor microenvironment 503 through the release of several biological molecules ranging from virions of mRNA, miRNA, 504 protein, lipid, and DNA cargos. An overview of the roles of exosomes in different types of 
cancer and the molecular mechanisms that have been used to evaluate the effect of EV in 506 cancer progression and metastasis were presented in Table 1. The exploration of exosomes 507 derived cancer cells contents may permit the progression of new diagnostic and remedial 508 procedures, with minimally invasive approaches. Exosomes derived cancer cells also can 509 cause cancer cell development and metastasis through suppressing the immune response $\quad 510$ and via enhancing chemoresistance by elimination of chemotherapeutic anti-cancer drugs. 511 So they might be significant targets for remedial interventions through their alternation or 512 elimination. The field of nanotechnology has widely benefitted exosome research to load 513 nanovesicles with tiny molecules or drugs for cancer treatment because of their small size, $\quad 514$ lack of toxicity and target specificity toward prosperous immunotherapy in clinical trials. 515 Besides exosomes can be considerable biomarkers for diagnosis of cancer and targeted 516 remedy due to their nearly display the situation of their parental cells that are relatively 517 constant in the blood circulation and could be feasibility obtained from body fluids. Most 518 significantly the role of miRNA in the context of exosomes for targeting inactivation of 519 cancer-causing miRNAs would probably provide a novel strategy for most cancers. It is $\mathbf{5 2 0}$ expected that further researches on these microvesicles will not only determine great 521 potential and hopeful effect on their functions in the pathogenesis of cancer but also will 522 open the new strategies for cancer diagnosis and remedies.

We thank Masoud Abak for the exact designing of figures that considerably improved the 525 quality of this manuscript. 
Adams A. 1973. Concentration of Epstein-Barr virus from cell culture fluids with polyethylene glycol. Journal of General Virology 20:391-394.

Al-Nedawi K, Meehan B, Micallef J, Lhotak V, May L, Guha A, and Rak J. 2008. Intercellular transfer of the oncogenic receptor EGFRvIII by microvesicles derived from tumour cells. Nature cell biology 10:619.

Alderton GK. 2012. Metastasis: Exosomes drive premetastatic niche formation. Nature Reviews Cancer 12:447.

Ali S, Suresh R, Banerjee S, Bao B, Xu Z, Wilson J, Philip PA, Apte M, and Sarkar FH. 2015. Contribution of microRNAs in understanding the pancreatic tumor microenvironment involving cancer associated stellate and fibroblast cells. American journal of cancer research 5:1251.

Allenson K, Castillo J, San Lucas F, Scelo G, Kim D, Bernard V, Davis G, Kumar T, Katz M, and Overman M. 2017. High prevalence of mutant KRAS in circulating exosome-derived DNA from early-stage pancreatic cancer patients. Annals of Oncology 28:741-747.

Andaloussi SE, Lakhal S, Mäger I, and Wood MJ. 2013. Exosomes for targeted siRNA delivery across biological barriers. Advanced drug delivery reviews 65:391-397.

Arita T, Ichikawa D, Konishi H, Komatsu S, Shiozaki A, Ogino S, Fujita Y, Hiramoto H, Hamada J, and Shoda K. 2016. Tumor exosome-mediated promotion of adhesion to mesothelial cells in gastric cancer cells. Oncotarget 7:56855.

Arscott WT, Tandle AT, Zhao S, Shabason JE, Gordon IK, Schlaff CD, Zhang G, Tofilon PJ, and Camphausen KA. 2013. Ionizing radiation and glioblastoma exosomes: implications in tumor biology and cell migration. Translational Oncology 6:638IN635-648IN636.

Aspe JR, Diaz Osterman CJ, Jutzy JM, Deshields S, Whang S, and Wall NR. 2014. Enhancement of Gemcitabine sensitivity in pancreatic adenocarcinoma by novel exosome-mediated delivery of the Survivin-T34A mutant. Journal of extracellular vesicles 3:23244.

Atay S, Banskota S, Crow J, Sethi G, Rink L, and Godwin AK. 2014. Oncogenic KIT-containing exosomes increase gastrointestinal stromal tumor cell invasion. Proceedings of the National Academy of Sciences 111:711-716.

Aung T, Chapuy B, Vogel D, Wenzel D, Oppermann M, Lahmann M, Weinhage T, Menck K, Hupfeld T, and Koch R. 2011. Exosomal evasion of humoral immunotherapy in aggressive B-cell lymphoma modulated by ATP-binding cassette transporter A3. Proceedings of the National Academy of Sciences 108:15336-15341.

Aushev VN, Zborovskaya IB, Laktionov KK, Girard N, Cros M-P, Herceg Z, and Krutovskikh V. 2013. Comparisons of microRNA patterns in plasma before and after tumor removal reveal new biomarkers of lung squamous cell carcinoma. PLoS One 8:e78649.

Azmi AS, Bao B, and Sarkar FH. 2013. Exosomes in cancer development, metastasis, and drug resistance: a comprehensive review. Cancer and Metastasis Reviews 32:623-642.

Baietti MF, Zhang Z, Mortier E, Melchior A, Degeest G, Geeraerts A, Ivarsson Y, Depoortere F, Coomans $C$, and Vermeiren E. 2012. Syndecan-syntenin-ALIX regulates the biogenesis of exosomes. Nature cell biology 14:677.

Balaj L, Lessard R, Dai L, Cho Y-J, Pomeroy SL, Breakefield XO, and Skog J. 2011. Tumour microvesicles contain retrotransposon elements and amplified oncogene sequences. Nature communications 2:180.

Bang C, and Thum T. 2012. Exosomes: new players in cell-cell communication. The international journal of biochemistry \& cell biology 44:2060-2064.

Beach A, Zhang H-G, Ratajczak MZ, and Kakar SS. 2014. Exosomes: an overview of biogenesis, composition and role in ovarian cancer. Journal of ovarian research 7:14.

534

536

539

541

544

547

549

552

558

561

565

568

570

573

576

578
537

538

540

542

543

545

546

548

550

551

553

554

556

557

559

560

562

563

564

566

567

569

571

572

574

575

577

579 
Bellavia D, Raimondo S, Calabrese G, Forte S, Cristaldi M, Patinella A, Memeo L, Manno M, Raccosta S, and Diana P. 2017. Interleukin 3-receptor targeted exosomes inhibit in vitro and in vivo Chronic Myelogenous Leukemia cell growth. Theranostics 7:1333.

Bhattacharya S, Pal K, Sharma AK, Dutta SK, Lau JS, Yan IK, Wang E, Elkhanany A, Alkharfy KM, and Sanyal A. 2014. GAIP interacting protein C-terminus regulates autophagy and exosome biogenesis of pancreatic cancer through metabolic pathways. PLoS One 9:e114409.

Boelens MC, Wu TJ, Nabet BY, Xu B, Qiu Y, Yoon T, Azzam DJ, Twyman-Saint Victor C, Wiemann BZ, and Ishwaran H. 2014. Exosome transfer from stromal to breast cancer cells regulates therapy resistance pathways. cell 159:499-513.

Bu N, Wu H, Sun B, Zhang G, Zhan S, Zhang R, and Zhou L. 2011. Exosome-loaded dendritic cells elicit tumor-specific CD8+ cytotoxic $\mathrm{T}$ cells in patients with glioma. Journal of Neuro-Oncology 104:659-667.

Cazzoli R, Buttitta F, Di Nicola M, Malatesta S, Marchetti A, Rom WN, and Pass HI. 2013. microRNAs derived from circulating exosomes as noninvasive biomarkers for screening and diagnosing lung cancer. Journal of Thoracic Oncology 8:1156-1162.

Challagundla KB, Wise PM, Neviani P, Chava H, Murtadha M, Xu T, Kennedy R, Ivan C, Zhang X, and Vannini I. 2015. Exosome-mediated transfer of microRNAs within the tumor microenvironment and neuroblastoma resistance to chemotherapy. JNCl: Journal of the National Cancer Institute 107.

Chalmin F, Ladoire S, Mignot G, Vincent J, Bruchard M, Remy-Martin J-P, Boireau W, Rouleau A, Simon B, and Lanneau D. 2010. Membrane-associated Hsp72 from tumor-derived exosomes mediates STAT3-dependent immunosuppressive function of mouse and human myeloid-derived suppressor cells. The Journal of clinical investigation 120:457.

Charrier A, Chen R, Chen L, Kemper S, Hattori T, Takigawa M, and Brigstock DR. 2014. Connective tissue growth factor (CCN2) and microRNA-21 are components of a positive feedback loop in pancreatic stellate cells (PSC) during chronic pancreatitis and are exported in PSC-derived exosomes. Journal of cell communication and signaling 8:147-156.

Chen C, Skog J, Hsu C-H, Lessard RT, Balaj L, Wurdinger T, Carter BS, Breakefield XO, Toner M, and Irimia D. 2010. Microfluidic isolation and transcriptome analysis of serum microvesicles. Lab on a Chip 10:505-511.

Chen W-x, Cai Y-q, Lv M-m, Chen L, Zhong S-I, Ma T-f, Zhao J-h, and Tang J-h. 2014. Exosomes from docetaxel-resistant breast cancer cells alter chemosensitivity by delivering microRNAs. Tumor Biology 35:9649-9659.

Chen W, Wang J, Shao C, Liu S, Yu Y, Wang Q, and Cao X. 2006. Efficient induction of antitumor T cell immunity by exosomes derived from heat-shocked lymphoma cells. European Journal of Immunology 36:1598-1607.

Chen Y, Zeng C, Zhan Y, Wang H, Jiang X, and Li W. 2017. Aberrant low expression of p85 $\alpha$ in stromal fibroblasts promotes breast cancer cell metastasis through exosome-mediated paracrine Wnt10b. Oncogene 36:4692.

Cheruvanky A, Zhou H, Pisitkun T, Kopp JB, Knepper MA, Yuen PS, and Star RA. 2007. Rapid isolation of urinary exosomal biomarkers using a nanomembrane ultrafiltration concentrator. American Journal of Physiology-Renal Physiology 292:F1657-F1661.

Cho JA, Yeo Dj, Son HY, Kim HW, Jung DS, Ko JK, Koh JS, Kim YN, and Kim CW. 2005. Exosomes: a new delivery system for tumor antigens in cancer immunotherapy. International journal of cancer 114:613-622.

Chun S, Ahn S, Yeom C-H, and Park S. 2016. Exosome Proteome of U-87MG Glioblastoma Cells. Biology 5:50.

580

583

581

582

584

585

586

587

588

589

590

591

592

593

594

595

596

597

598

599

600

601

602

603

604

605

606

607

610

608

609

611

612

613

616

614

615

617

618

619

620

621

622

623

624

625

626 
Clayton A, Mitchell JP, Mason MD, and Tabi Z. 2007. Human tumor-derived exosomes selectively impair lymphocyte responses to interleukin-2. Cancer research 67:7458-7466.

Conde-Vancells J, Rodriguez-Suarez E, Gonzalez E, Berisa A, Gil D, Embade N, Valle M, Luka Z, Elortza F, and Wagner C. 2010. Candidate biomarkers in exosome-like vesicles purified from rat and mouse urine samples. PROTEOMICS-Clinical Applications 4:416-425.

Corcoran C, Rani S, O’Brien K, O'Neill A, Prencipe M, Sheikh R, Webb G, McDermott R, Watson W, and Crown J. 2012. Docetaxel-resistance in prostate cancer: evaluating associated phenotypic changes and potential for resistance transfer via exosomes. PLoS One 7:e50999.

Corrado C, Raimondo S, Saieva L, Flugy AM, De Leo G, and Alessandro R. 2014. Exosome-mediated crosstalk between chronic myelogenous leukemia cells and human bone marrow stromal cells triggers an interleukin 8-dependent survival of leukemia cells. Cancer letters 348:71-76.

Damo M, Wilson DS, Simeoni E, and Hubbell JA. 2015. TLR-3 stimulation improves anti-tumor immunity elicited by dendritic cell exosome-based vaccines in a murine model of melanoma. Scientific reports 5:17622.

De Veirman K, Wang J, Xu S, Leleu X, Himpe E, Maes K, De Bruyne E, Van Valckenborgh E, Vanderkerken $\mathrm{K}$, and Menu E. 2016. Induction of miR-146a by multiple myeloma cells in mesenchymal stromal cells stimulates their pro-tumoral activity. Cancer letters 377:17-24.

Desrochers LM, Antonyak MA, and Cerione RA. 2016. Extracellular vesicles: satellites of information transfer in cancer and stem cell biology. Developmental Cell 37:301-309.

Dijkstra S, Birker IL, Smit FP, Leyten GH, de Reijke TM, van Oort IM, Mulders PF, Jannink SA, and Schalken JA. 2014. Prostate cancer biomarker profiles in urinary sediments and exosomes. The Journal of urology 191:1132-1138.

Ding X, Ma M, Teng J, Teng RK, Zhou S, Yin J, Fonkem E, Huang JH, Wu E, and Wang X. 2015. Exposure to ALS-FTD-CSF generates TDP-43 aggregates in glioblastoma cells through exosomes and TNTs-like structure. Oncotarget 6:24178.

Dvorak HF. 1986. Tumors: wounds that do not heal. New England Journal of Medicine 315:1650-1659.

Dvorak HF, Weaver VM, Tlsty TD, and Bergers G. 2011. Tumor microenvironment and progression. Journal of Surgical Oncology 103:468-474.

Ekström EJ, Bergenfelz C, von Bülow V, Serifler F, Carlemalm E, Jönsson G, Andersson T, and Leandersson K. 2014. WNT5A induces release of exosomes containing pro-angiogenic and immunosuppressive factors from malignant melanoma cells. Molecular cancer 13:88.

El-Saghir J, Nassar F, Tawil N, and El-Sabban M. 2016. ATL-derived exosomes modulate mesenchymal stem cells: potential role in leukemia progression. Retrovirology 13:73.

Eldh M, Bagge RO, Lässer C, Svanvik J, Sjöstrand M, Mattsson J, Lindnér P, Choi D-S, Gho YS, and Lötvall J. 2014. MicroRNA in exosomes isolated directly from the liver circulation in patients with metastatic uveal melanoma. BMC cancer 14:962.

Escudier B, Dorval T, Chaput N, André F, Caby M-P, Novault S, Flament C, Leboulaire C, Borg C, and Amigorena S. 2005. Vaccination of metastatic melanoma patients with autologous dendritic cell (DC) derived-exosomes: results of thefirst phase I clinical trial. Journal of Translational Medicine 3:10.

Fabbri M, Paone A, Calore F, Galli R, Gaudio E, Santhanam R, Lovat F, Fadda P, Mao C, and Nuovo GJ. 2012. MicroRNAs bind to Toll-like receptors to induce prometastatic inflammatory response. Proceedings of the National Academy of Sciences 109:E2110-E2116.

Farrow B, Rychahou P, Murillo C, O'connor KL, Iwamura T, and Evers BM. 2003. Inhibition of pancreatic cancer cell growth and induction of apoptosis with novel therapies directed against protein kinase A. Surgery 134:197-205.

627

629

632

628

630

631

633

634

635

636

637

638

639

640

641

644

646

642

643

645

647

648

649

650

651

652

653

655

654

656

657

658

660

663

667

670

659

661

662

664

665

666

668

669

671

672 
Federici C, Petrucci F, Caimi S, Cesolini A, Logozzi M, Borghi M, D'llio S, Lugini L, Violante N, and Azzarito T. 2014. Exosome release and low pH belong to a framework of resistance of human melanoma cells to cisplatin. PLoS One 9:e88193.

Feng D-Q, Huang B, Li J, Liu J, Chen X-M, Xu Y-M, Chen X, Zhang H-B, Hu L-H, and Wang X-Z. 2013. Selective miRNA expression profile in chronic myeloid leukemia K562 cell-derived exosomes. Asian Pacific Journal of Cancer Prevention 14:7501-7508.

Février B, and Raposo G. 2004. Exosomes: endosomal-derived vesicles shipping extracellular messages. Current Opinion in Cell Biology 16:415-421.

Fleming A, Sampey G, Chung MC, Bailey C, van Hoek ML, Kashanchi F, and Hakami RM. 2014. The carrying pigeons of the cell: exosomes and their role in infectious diseases caused by human pathogens. Pathogens and disease 71:109-120.

Fonsato V, Collino F, Herrera MB, Cavallari C, Deregibus MC, Cisterna B, Bruno S, Romagnoli R, Salizzoni M, and Tetta C. 2012. Human Liver Stem Cell-Derived Microvesicles Inhibit Hepatoma Growth in SCID Mice by Delivering Antitumor MicroRNAs. Stem Cells 30:1985-1998.

Gajos-Michniewicz A, Duechler M, and Czyz M. 2014. MiRNA in melanoma-derived exosomes. Cancer letters 347:29-37.

Gamperl H, Plattfaut C, Freund A, Quecke T, Theophil F, and Gieseler F. 2016. Extracellular vesicles from malignant effusions induce tumor cell migration: inhibitory effect of LMWH tinzaparin. Cell Biology International 40:1050-1061.

Grange C, Tapparo M, Collino F, Vitillo L, Damasco C, Deregibus MC, Tetta C, Bussolati B, and Camussi G. 2011. Microvesicles released from human renal cancer stem cells stimulate angiogenesis and formation of lung premetastatic niche. Cancer research 71:5346-5356.

Hall J, Prabhakar S, Balaj L, Lai CP, Cerione RA, and Breakefield XO. 2016. Delivery of therapeutic proteins via extracellular vesicles: review and potential treatments for Parkinson's disease, Glioma, and Schwannoma. Cellular and Molecular Neurobiology 36:417-427.

Hannafon BN, and Ding W-Q. 2013. Intercellular communication by exosome-derived microRNAs in cancer. International Journal of Molecular Sciences 14:14240-14269.

Harding CV, Heuser JE, and StahI PD. 2013. Exosomes: looking back three decades and into the future. Journal of Cell Biology 200:367-371.

Harshman SW, Canella A, Ciarlariello PD, Rocci A, Agarwal K, Smith EM, Talabere T, Efebera YA, Hofmeister CC, and Benson DM. 2013. Characterization of multiple myeloma vesicles by label-free relative quantitation. Proteomics 13:3013-3029.

Harshyne LA, Hooper KM, Andrews EG, Nasca BJ, Kenyon LC, Andrews DW, and Hooper DC. $2015 a$. Glioblastoma exosomes and IGF-1R/AS-ODN are immunogenic stimuli in a translational research immunotherapy paradigm. Cancer Immunology, Immunotherapy 64:299-309.

Harshyne LA, Nasca BJ, Kenyon LC, Andrews DW, and Hooper DC. 2015b. Serum exosomes and cytokines promote a T-helper cell type 2 environment in the peripheral blood of glioblastoma patients. Neuro-Oncology 18:206-215.

Hazan-Halevy I, Rosenblum D, Weinstein S, Bairey O, Raanani P, and Peer D. 2015. Cell-specific uptake of mantle cell lymphoma-derived exosomes by malignant and non-malignant B-lymphocytes. Cancer letters 364:59-69.

He M, Qin H, Poon TC, Sze S-C, Ding X, Co NN, Ngai S-M, Chan T-F, and Wong N. 2015. Hepatocellular carcinoma-derived exosomes promote motility of immortalized hepatocyte through transfer of oncogenic proteins and RNAs. Carcinogenesis 36:1008-1018.

Hedlund M, Nagaeva O, Kargl D, Baranov V, and Mincheva-Nilsson L. 2011. Thermal-and oxidative stress causes enhanced release of NKG2D ligand-bearing immunosuppressive exosomes in leukemia/lymphoma T and B cells. PLoS One 6:e16899.

673

676

679

681

684

687

689

692

695

698

700

702

705

711

712

713

714

715

716

717

718

719 
Herrera M, Fonsato V, Gatti S, Deregibus M, Sordi A, Cantarella D, Calogero R, Bussolati B, Tetta C, and 720 Camussi G. 2010. Human liver stem cell-derived microvesicles accelerate hepatic regeneration in hepatectomized rats. Journal of Cellular and Molecular Medicine 14:1605-1618.

Higginbotham JN, Beckler MD, Gephart JD, Franklin JL, Bogatcheva G, Kremers G-J, Piston DW, Ayers GD, McConnell RE, and Tyska MJ. 2011. Amphiregulin exosomes increase cancer cell invasion. Current Biology 21:779-786.

Hong C-S, Muller L, Whiteside TL, and Boyiadzis M. 2014a. Plasma exosomes as markers of therapeutic response in patients with acute myeloid leukemia. Frontiers in Immunology 5.

Hong CS, Muller L, Boyiadzis M, and Whiteside TL. 2014b. Isolation and characterization of CD34+ blastderived exosomes in acute myeloid leukemia. PLoS One 9:e103310.

Hood JL, San RS, and Wickline SA. 2011. Exosomes released by melanoma cells prepare sentinel lymph nodes for tumor metastasis. Cancer research 71:3792-3801.

Hosseini HM, Fooladi AAI, Soleimanirad J, Nourani MR, Davaran S, and Mahdavi M. 2014. Staphylococcal entorotoxin B anchored exosome induces apoptosis in negative esterogen receptor breast cancer cells. Tumor Biology 35:3699-3707.

Huan J, Hornick NI, Shurtleff MJ, Skinner AM, Goloviznina NA, Roberts CT, and Kurre P. 2013. RNA trafficking by acute myelogenous leukemia exosomes. Cancer research 73:918-929.

Huang M-B, Gonzalez RR, Lillard J, and Bond VC. 2017. Secretion modification region-derived peptide blocks exosome release and mediates cell cycle arrest in breast cancer cells. Oncotarget 8:11302.

Hung ME, and Leonard JN. 2015. Stabilization of exosome-targeting peptides via engineered glycosylation. Journal of Biological Chemistry 290:8166-8172.

Hwang I. 2013. Cell-cell communication via extracellular membrane vesicles and its role in the immune response. Molecules and Cells 36:105-111.

lessi E, Logozzi M, Lugini L, Azzarito T, Federici C, Spugnini EP, Mizzoni D, Di Raimo R, Angelini DF, and Battistini L. 2017. Acridine Orange/exosomes increase the delivery and the effectiveness of Acridine Orange in human melanoma cells: A new prototype for theranostics of tumors. Journal of Enzyme Inhibition and Medicinal Chemistry 32:648-657.

Jang SC, Kim OY, Yoon CM, Choi D-S, Roh T-Y, Park J, Nilsson J, Lötvall J, Kim Y-K, and Gho YS. 2013. Bioinspired exosome-mimetic nanovesicles for targeted delivery of chemotherapeutics to malignant tumors. ACS nano 7:7698-7710.

Jeppesen DK, Nawrocki A, Jensen SG, Thorsen K, Whitehead B, Howard KA, Dyrskjøt L, Ørntoft TF, Larsen MR, and Ostenfeld MS. 2014. Quantitative proteomics of fractionated membrane and lumen exosome proteins from isogenic metastatic and nonmetastatic bladder cancer cells reveal differential expression of EMT factors. Proteomics 14:699-712.

Joanne LY, May L, Lhotak V, Shahrzad S, Shirasawa S, Weitz JI, Coomber BL, Mackman N, and Rak JW. 2005. Oncogenic events regulate tissue factor expression in colorectal cancer cells: implications for tumor progression and angiogenesis. Blood 105:1734-1741.

Jung T, Castellana D, Klingbeil P, Hernández IC, Vitacolonna M, Orlicky DJ, Roffler SR, Brodt P, and Zöller M. 2009. CD44v6 dependence of premetastatic niche preparation by exosomes. Neoplasia 11:IN13-IN17.

Kalluri R, and Zeisberg M. 2006. Fibroblasts in cancer. Nature reviews Cancer 6:392.

Kim MS, Haney MJ, Zhao Y, Mahajan V, Deygen I, Klyachko NL, Inskoe E, Piroyan A, Sokolsky M, and Okolie O. 2016. Development of exosome-encapsulated paclitaxel to overcome MDR in cancer cells. Nanomedicine: Nanotechnology, Biology and Medicine 12:655-664.

Ko S-F, Yip H-K, Zhen Y-Y, Lee C-C, Lee C-C, Huang C-C, Ng S-H, and Lin J-W. 2015. Adipose-derived mesenchymal stem cell exosomes suppress hepatocellular carcinoma growth in a rat model:

721

722

723

724

725

726

728

730

732

727

729

731

733

734

735

737

736

738

739

740

742

744

741

743

745

746

747

748

751

749

750

752

753

754

755

756

757

758

759

760

761

762

763

764

765

766 
apparent diffusion coefficient, natural killer T-cell responses, and histopathological features. Stem cells international 2015.

Koch R, Demant M, Aung T, Diering N, Cicholas A, Chapuy B, Wenzel D, Lahmann M, Güntsch A, and Kiecke C. 2014. Populational equilibrium through exosome-mediated Wnt signaling in tumor progression of diffuse large B-cell lymphoma. Blood 123:2189-2198.

Kogure T, Lin WL, Yan IK, Braconi C, and Patel T. 2011. Intercellular nanovesicle-mediated microRNA transfer: A mechanism of environmental modulation of hepatocellular cancer cell growth. Hepatology 54:1237-1248.

Kong JN, He Q, Wang G, Dasgupta S, Dinkins MB, Zhu G, Kim A, Spassieva S, and Bieberich E. 2015. Guggulsterone and bexarotene induce secretion of exosome-associated breast cancer resistance protein and reduce doxorubicin resistance in MDA-MB-231 cells. International journal of cancer 137:1610-1620.

Kooijmans SA, Aleza CG, Roffler SR, van Solinge WW, Vader P, and Schiffelers RM. 2016. Display of GPIanchored anti-EGFR nanobodies on extracellular vesicles promotes tumour cell targeting. Journal of extracellular vesicles 5:31053.

Kore RA, and Abraham EC. 2014. Inflammatory cytokines, interleukin-1 beta and tumor necrosis factoralpha, upregulated in glioblastoma multiforme, raise the levels of CRYAB in exosomes secreted by U373 glioma cells. Biochemical and Biophysical Research Communications 453:326-331.

Kowal J, Tkach M, and Théry C. 2014. Biogenesis and secretion of exosomes. Current Opinion in Cell Biology 29:116-125.

Kruger S, Elmageed ZYA, Hawke DH, Wörner PM, Jansen DA, Abdel-Mageed AB, Alt EU, and Izadpanah R. 2014. Molecular characterization of exosome-like vesicles from breast cancer cells. BMC cancer 14:44.

Kucharzewska P, and Belting M. 2013. Emerging roles of extracellular vesicles in the adaptive response of tumour cells to microenvironmental stress. Journal of extracellular vesicles 2:20304.

Kucharzewska P, Christianson HC, Welch JE, Svensson KJ, Fredlund E, Ringnér M, Mörgelin M, BourseauGuilmain E, Bengzon J, and Belting M. 2013. Exosomes reflect the hypoxic status of glioma cells and mediate hypoxia-dependent activation of vascular cells during tumor development. Proceedings of the National Academy of Sciences 110:7312-7317.

Lai RC, Arslan F, Lee MM, Sze NSK, Choo A, Chen TS, Salto-Tellez M, Timmers L, Lee CN, and El Oakley RM. 2010. Exosome secreted by MSC reduces myocardial ischemia/reperfusion injury. Stem cell research 4:214-222.

Lai RC, Tan SS, Teh BJ, Sze SK, Arslan F, De Kleijn DP, Choo A, and Lim SK. 2012. Proteolytic potential of the MSC exosome proteome: implications for an exosome-mediated delivery of therapeutic proteasome. International journal of proteomics 2012.

Lau CS, and Wong DT. 2012. Breast cancer exosome-like microvesicles and salivary gland cells interplay alters salivary gland cell-derived exosome-like microvesicles in vitro. PLoS One 7:e33037.

Lazar I, Clement E, Dauvillier S, Milhas D, Ducoux-Petit M, LeGonidec S, Moro C, Soldan V, Dalle S, and Balor S. 2016. Adipocyte exosomes promote melanoma aggressiveness through fatty acid oxidation: a novel mechanism linking obesity and cancer. Cancer research 76:4051-4057.

Lehmann BD, Paine MS, Brooks AM, McCubrey JA, Renegar RH, Wang R, and Terrian DM. 2008. Senescence-associated exosome release from human prostate cancer cells. Cancer research 68:7864-7871.

Lespagnol A, Duflaut D, Beekman C, Blanc L, Fiucci G, Marine J, Vidal M, Amson R, and Telerman A. 2008. Exosome secretion, including the DNA damage-induced p53-dependent secretory pathway, is severely compromised in TSAP6/Steap3-null mice. Cell Death and Differentiation 15:1723. 
Lewis GD, and Metcalf TG. 1988. Polyethylene glycol precipitation for recovery of pathogenic viruses, including hepatitis $A$ virus and human rotavirus, from oyster, water, and sediment samples. Applied and Environmental Microbiology 54:1983-1988.

Li C, Liu D-R, Li G-G, Wang H-H, Li X-W, Zhang W, Wu Y-L, and Chen L. 2015. CD97 promotes gastric cancer cell proliferation and invasion through exosome-mediated MAPK signaling pathway. World Journal of Gastroenterology: WJG 21:6215.

Li J, Chen Y, Guo X, Zhou L, Jia Z, Peng Z, Tang Y, Liu W, Zhu B, and Wang L. 2017. GPC1 exosome and its regulatory miRNAs are specific markers for the detection and target therapy of colorectal cancer. Journal of Cellular and Molecular Medicine 21:838-847.

Li J, Liu A, and Wang Y. 2014. $\beta$-Elemene against human lung cancer via up-regulation of P53 protein expression to promote the release of exosome. Lung Cancer 86:144-150.

Li Y, and Bahassi EM. 2013. Biofluid-based circulating tumor molecules as diagnostic tools for use in personalized medicine. Journal of Molecular Biomarkers \& Diagnosis 5:157-163.

Liao J, Liu R, Shi Y-J, Yin L-H, and Pu Y-P. 2016. Exosome-shuttling microRNA-21 promotes cell migration and invasion-targeting PDCD4 in esophageal cancer. International journal of oncology 48:25672579.

Lim JW, Mathias RA, Kapp EA, Layton MJ, Faux MC, Burgess AW, Ji H, and Simpson RJ. 2012. Restoration of full-length APC protein in SW480 colon cancer cells induces exosome-mediated secretion of DKK-4. Electrophoresis 33:1873-1880.

Liu J, Zhang Y, Liu A, Wang J, Li L, Chen X, Gao X, Xue Y, Zhang X, and Liu Y. 2016. Distinct dasatinibinduced mechanisms of apoptotic response and exosome release in imatinib-resistant human chronic myeloid leukemia cells. International Journal of Molecular Sciences 17:531.

Liu W-h, Ren L-n, Wang X, Wang T, Zhang N, Gao Y, Luo H, Navarro-Alvarez N, and Tang L-j. 2015. Combination of exosomes and circulating microRNAs may serve as a promising tumor marker complementary to alpha-fetoprotein for early-stage hepatocellular carcinoma diagnosis in rats. Journal of Cancer Research and Clinical Oncology 141:1767-1778.

Liu Z-M, Wang Y-B, and Yuan X-H. 2013. Exosomes from murine-derived GL26 cells promote glioblastoma tumor growth by reducing number and function of CD8+ T cells. Asian Pacific Journal of Cancer Prevention 14:309-314.

Logozzi M, De Milito A, Lugini L, Borghi M, Calabro L, Spada M, Perdicchio M, Marino ML, Federici C, and lessi E. 2009. High levels of exosomes expressing CD63 and caveolin-1 in plasma of melanoma patients. PLoS One 4:e5219.

Lötvall J, Hill AF, Hochberg F, Buzás EI, Di Vizio D, Gardiner C, Gho YS, Kurochkin IV, Mathivanan S, and Quesenberry P. 2014. Minimal experimental requirements for definition of extracellular vesicles and their functions: a position statement from the International Society for Extracellular Vesicles. Taylor \& Francis.

Luketic L, Delanghe J, Sobol PT, Yang P, Frotten E, Mossman KL, Gauldie J, Bramson J, and Wan Y. 2007. Antigen presentation by exosomes released from peptide-pulsed dendritic cells is not suppressed by the presence of active CTL. The Journal of Immunology 179:5024-5032.

Lv L-H, Wan Y-L, Lin Y, Zhang W, Yang M, Li G-L, Lin H-M, Shang C-Z, Chen Y-J, and Min J. 2012. Anticancer drugs cause release of exosomes with heat shock proteins from human hepatocellular carcinoma cells that elicit effective natural killer cell antitumor responses in vitro. Journal of Biological Chemistry 287:15874-15885.

Madhavan B, Yue S, Galli U, Rana S, Gross W, Müller M, Giese NA, Kalthoff H, Becker T, and Büchler MW. 2015. Combined evaluation of a panel of protein and miRNA serum-exosome biomarkers for pancreatic cancer diagnosis increases sensitivity and specificity. International journal of cancer 136:2616-2627. 
Mahmoodzadeh HH, Ali IFA, Soleimanirad J, Reza NM, and Mahdavi M. 2014. Exosome/staphylococcal enterotoxin B, an anti tumor compound against pancreatic cancer. Journal of BU ON: official journal of the Balkan Union of Oncology 19:440-448.

Malhotra H, Sheokand N, Kumar S, Chauhan AS, Kumar M, Jakhar P, Boradia VM, Raje Cl, and Raje M. 2016. Exosomes: tunable nano vehicles for macromolecular delivery of transferrin and lactoferrin to specific intracellular compartment. Journal of biomedical nanotechnology 12:11011114.

Mathivanan S, Ji H, and Simpson RJ. 2010. Exosomes: extracellular organelles important in intercellular communication. Journal of Proteomics 73:1907-1920.

McKiernan J, Donovan MJ, O’Neill V, Bentink S, Noerholm M, Belzer S, Skog J, Kattan MW, Partin A, and Andriole G. 2016. A novel urine exosome gene expression assay to predict high-grade prostate cancer at initial biopsy. JAMA oncology 2:882-889.

Menay F, Herschlik L, De Toro J, Cocozza F, Tsacalian R, Gravisaco MJ, Di Sciullo MP, Vendrell A, Waldner $\mathrm{Cl}$, and Mongini C. 2017. exosomes isolated from ascites of T-cell lymphoma-Bearing Mice expressing surface cD24 and hsP-90 induce a Tumor-specific immune response. Frontiers in Immunology 8.

Mineo M, Garfield SH, Taverna S, Flugy A, De Leo G, Alessandro R, and Kohn EC. 2012. Exosomes released by $\mathrm{K} 562$ chronic myeloid leukemia cells promote angiogenesis in a Src-dependent fashion. Angiogenesis 15:33-45.

Miyanishi M, Tada K, Koike M, Uchiyama Y, Kitamura T, and Nagata S. 2007. Identification of Tim4 as a phosphatidylserine receptor. Nature 450:435.

Moon P-G, Lee J-E, Cho Y-E, Lee SJ, Jung JH, Chae YS, Bae H-I, Kim Y-B, Kim I-S, and Park HY. 2016. Identification of developmental endothelial locus-1 on circulating extracellular vesicles as a novel biomarker for early breast cancer detection. Clinical Cancer Research 22:1757-1766.

Muhsin-Sharafaldine M-R, Saunderson SC, Dunn AC, Faed JM, Kleffmann T, and McLellan AD. 2016. Procoagulant and immunogenic properties of melanoma exosomes, microvesicles and apoptotic vesicles. Oncotarget 7:56279.

Munoz JL, Bliss SA, Greco SJ, Ramkissoon SH, Ligon KL, and Rameshwar P. 2013. Delivery of functional anti-miR-9 by mesenchymal stem cell-derived exosomes to glioblastoma multiforme cells conferred chemosensitivity. Molecular Therapy-Nucleic Acids 2:e126.

Nagaraj S, and Gabrilovich DI. 2012. Regulation of suppressive function of myeloid-derived suppressor cells by CD4+ T cells. Seminars in Cancer Biology: Elsevier. p 282-288.

Nazarenko I, Rana S, Baumann A, McAlear J, Hellwig A, Trendelenburg M, Lochnit G, Preissner KT, and Zöller M. 2010. Cell surface tetraspanin Tspan8 contributes to molecular pathways of exosomeinduced endothelial cell activation. Cancer research 70:1668-1678.

Nilsson J, Skog J, Nordstrand A, Baranov V, Mincheva-Nilsson L, Breakefield X, and Widmark A. 2009. Prostate cancer-derived urine exosomes: a novel approach to biomarkers for prostate cancer. British journal of cancer 100:1603.

Ohno S-i, Takanashi M, Sudo K, Ueda S, Ishikawa A, Matsuyama N, Fujita K, Mizutani T, Ohgi T, and Ochiya T. 2013. Systemically injected exosomes targeted to EGFR deliver antitumor microRNA to breast cancer cells. Molecular Therapy 21:185-191.

Ohshima K, Kanto K, Hatakeyama K, Ide T, Wakabayashi-Nakao K, Watanabe Y, Sakura N, Terashima M, Yamaguchi K, and Mochizuki T. 2014. Exosome-mediated extracellular release of polyadenylate-binding protein 1 in human metastatic duodenal cancer cells. Proteomics 14:2297-2306.

Oksvold MP, Kullmann A, Forfang L, Kierulf B, Li M, Brech A, Vlassov AV, Smeland EB, Neurauter A, and Pedersen KW. 2014. Expression of B-cell surface antigens in subpopulations of exosomes released from B-cell lymphoma cells. Clinical Therapeutics 36:847-862. e841.

863

861

862

864

865

866

867

869

868

870

871

872

873

874

875

876

879

881

884

887

890

892

895

898

877

878

880

882

883

885

886

888

889

891

893

894

896

897

899

900

901

902

903

904

905

906

907 
Ostenfeld MS, Jeppesen DK, Laurberg JR, Boysen AT, Bramsen JB, Primdal-Bengtson B, Hendrix A, Lamy P, Dagnaes-Hansen F, and Rasmussen MH. 2014. Cellular disposal of miR23b by RAB27dependent exosome release is linked to acquisition of metastatic properties. Cancer research 74:5758-5771.

Ostrowski M, Carmo NB, Krumeich S, Fanget I, Raposo G, Savina A, Moita CF, Schauer K, Hume AN, and Freitas RP. 2010. Rab27a and Rab27b control different steps of the exosome secretion pathway. Nature cell biology 12:19.

Paggetti J, Haderk F, Seiffert M, Janji B, Distler U, Ammerlaan W, Kim YJ, Adam J, Lichter P, and Solary E. 2015. Exosomes released by chronic lymphocytic leukemia cells induce the transition of stromal cells into cancer-associated fibroblasts. Blood 126:1106-1117.

Pant S, Hilton H, and Burczynski ME. 2012. The multifaceted exosome: biogenesis, role in normal and aberrant cellular function, and frontiers for pharmacological and biomarker opportunities. Biochemical Pharmacology 83:1484-1494.

Park J, Hwang M, Choi B, Jeong H, Jung J-h, Kim HK, Hong S, Park JH, and Choi Y. 2017. Exosome Classification by Pattern Analysis of Surface-enhanced Raman Spectroscopy Data for Lung Cancer Diagnosis. Analytical Chemistry.

Park S, Ahn ES, and Kim Y. 2015. Neuroblastoma SH-SY5Y cell-derived exosomes stimulate dendrite-like outgrowths and modify the differentiation of A375 melanoma cells. Cell Biology International 39:379-387.

Parolini I, Federici C, Raggi C, Lugini L, Palleschi S, De Milito A, Coscia C, lessi E, Logozzi M, and Molinari A. 2009. Microenvironmental $\mathrm{pH}$ is a key factor for exosome traffic in tumor cells. Journal of Biological Chemistry 284:34211-34222.

Patel SJ, Darie CC, and Clarkson BD. 2016. Exosome mediated growth effect on the non-growing pre-B acute lymphoblastic leukemia cells at low starting cell density. American Journal of Translational Research 8:3614.

Peinado H, Alec`ković M, Lavotshkin S, Matei I, Costa-Silva B, Moreno-Bueno G, Hergueta-Redondo M, Williams C, García-Santos G, and Ghajar CM. 2016. Corrigendum: Melanoma exosomes educate bone marrow progenitor cells toward a pro-metastatic phenotype through MET. Nature Medicine 22:1502.

Peinado H, Alečković M, Lavotshkin S, Matei I, Costa-Silva B, Moreno-Bueno G, Hergueta-Redondo M, Williams C, García-Santos G, and Ghajar CM. 2012. Melanoma exosomes educate bone marrow progenitor cells toward a pro-metastatic phenotype through MET. Nature Medicine 18:883-891.

Philley JV, Kannan A, Griffith DE, Devine MS, Benwill JL, Wallace Jr RJ, Brown-Elliott BA, Thakkar F, Taskar V, and Fox JG. 2017. Exosome secretome and mediated signaling in breast cancer patients with nontuberculous mycobacterial disease. Oncotarget 8:18070.

Pinet S, Bessette B, Vedrenne N, Lacroix A, Richard L, Jauberteau M-O, Battu S, and Lalloué F. 2016. TrkB-containing exosomes promote the transfer of glioblastoma aggressiveness to YKL-40inactivated glioblastoma cells. Oncotarget 7:50349.

Qu J-L, Qu X-J, Qu J-L, Qu X-J, Zhao M-F, Teng Y-E, Zhang Y, Hou K-Z, Jiang Y-H, and Yang X-H. 2009. The role of cbl family of ubiquitin ligases in gastric cancer exosome-induced apoptosis of Jurkat $\mathrm{T}$ cells. Acta Oncologica 48:1173-1180.

Qu L, Ding J, Chen C, Wu Z-J, Liu B, Gao Y, Chen W, Liu F, Sun W, and Li X-F. 2016a. Exosome-transmitted IncARSR promotes sunitinib resistance in renal cancer by acting as a competing endogenous RNA. Cancer cell 29:653-668.

Qu Z, Wu J, Wu J, Luo D, Jiang C, and Ding Y. 2016b. Exosomes derived from HCC cells induce sorafenib resistance in hepatocellular carcinoma both in vivo and in vitro. Journal of Experimental and Clinical Cancer Research 35:159. 
Que R-s, Lin C, Ding G-p, Wu Z-r, and Cao L-p. 2016. Increasing the immune activity of exosomes: the effect of miRNA-depleted exosome proteins on activating dendritic cell/cytokine-induced killer cells against pancreatic cancer. Journal of Zhejiang University SCIENCE B 17:352-360.

Rabinowits G, Gerçel-Taylor C, Day JM, Taylor DD, and Kloecker GH. 2009. Exosomal microRNA: a diagnostic marker for lung cancer. Clinical Lung Cancer 10:42-46.

Ragusa M, Barbagallo C, Statello L, Caltabiano R, Russo A, Puzzo L, Avitabile T, Longo A, Toro MD, and Barbagallo D. 2015. miRNA profiling in vitreous humor, vitreal exosomes and serum from uveal melanoma patients: Pathological and diagnostic implications. Cancer Biology \& Therapy 16:1387-1396.

Raimondo F, Morosi L, Chinello C, Magni F, and Pitto M. 2011. Advances in membranous vesicle and exosome proteomics improving biological understanding and biomarker discovery. Proteomics 11:709-720.

Raimondo S, Saieva L, Corrado C, Fontana S, Flugy A, Rizzo A, De Leo G, and Alessandro R. 2015. Chronic myeloid leukemia-derived exosomes promote tumor growth through an autocrine mechanism. Cell Communication and Signaling 13:8.

Ramteke A, Ting H, Agarwal C, Mateen S, Somasagara R, Hussain A, Graner M, Frederick B, Agarwal R, and Deep G. 2015. Exosomes secreted under hypoxia enhance invasiveness and stemness of prostate cancer cells by targeting adherens junction molecules. Molecular carcinogenesis 54:554-565.

Raposo G, Nijman HW, Stoorvogel W, Liejendekker R, Harding CV, Melief CJ, and Geuze HJ. 1996. B lymphocytes secrete antigen-presenting vesicles. Journal of Experimental Medicine 183:11611172.

Record M, Carayon K, Poirot M, and Silvente-Poirot S. 2014. Exosomes as new vesicular lipid transporters involved in cell-cell communication and various pathophysiologies. Biochimica et Biophysica Acta (BBA)-Molecular and Cell Biology of Lipids 1841:108-120.

Ristorcelli E, Beraud E, Verrando P, Villard C, Lafitte D, Sbarra V, Lombardo D, and Verine A. 2008. Human tumor nanoparticles induce apoptosis of pancreatic cancer cells. The FASEB Journal 22:3358-3369.

Rodríguez M, Silva J, López-Alfonso A, López-Muñiz MB, Peña C, Domínguez G, García JM, López-Gónzalez A, Méndez M, and Provencio M. 2014. Different exosome cargo from plasma/bronchoalveolar lavage in non-small-cell lung cancer. Genes, Chromosomes and Cancer 53:713-724.

Roma-Rodrigues C, Fernandes AR, and Baptista PV. 2014. Exosome in tumour microenvironment: overview of the crosstalk between normal and cancer cells. BioMed research international 2014.

Ruiz-Martinez M, Navarro A, Marrades RM, Viñolas N, Santasusagna S, Muñoz C, Ramírez J, Molins L, and Monzo M. 2016. YKT6 expression, exosome release, and survival in non-small cell lung cancer. Oncotarget 7:51515.

Saari H, Lazaro-Ibanez E, Viitala T, Vuorimaa-Laukkanen E, Siljander P, and Yliperttula M. 2015. Microvesicle-and exosome-mediated drug delivery enhances the cytotoxicity of Paclitaxel in autologous prostate cancer cells. Journal of Controlled Release 220:727-737.

Saeki M, Egusa H, Kamano Y, Kakihara Y, Houry WA, Yatani H, Noguchi S, and Kamisaki Y. 2013. Exosome-bound WD repeat protein Monad inhibits breast cancer cell invasion by degrading amphiregulin mRNA. PLoS One 8:e67326.

Safaei R, Larson BJ, Cheng TC, Gibson MA, Otani S, Naerdemann W, and Howell SB. 2005. Abnormal lysosomal trafficking and enhanced exosomal export of cisplatin in drug-resistant human ovarian carcinoma cells. Molecular cancer therapeutics 4:1595-1604. 
Sagar G, Sah RP, Javeed N, Dutta SK, Smyrk TC, Lau JS, Giorgadze N, Tchkonia T, Kirkland JL, and Chari ST. 2015. Pathogenesis of pancreatic cancer exosome-induced lipolysis in adipose tissue. Gut:gutjnl2014-308350.

Segura E, Nicco C, Lombard B, Véron P, Raposo G, Batteux F, Amigorena S, and Théry C. 2005. ICAM-1 on exosomes from mature dendritic cells is critical for efficient naive T-cell priming. Blood 106:216223.

Sharma S, Das K, Woo J, and Gimzewski JK. 2014. Nanofilaments on glioblastoma exosomes revealed by peak force microscopy. Journal of The Royal Society Interface 11:20131150.

Shedden K, Xie XT, Chandaroy P, Chang YT, and Rosania GR. 2003. Expulsion of Small Molecules in Vesicles Shed by Cancer Cells. Cancer research 63:4331-4337.

Shigoka M, Tsuchida A, Matsudo T, Nagakawa Y, Saito H, Suzuki Y, Aoki T, Murakami Y, Toyoda H, and Kumada T. 2010. Deregulation of miR-92a expression is implicated in hepatocellular carcinoma development. Pathology International 60:351-357.

Silva J, Garcia V, Rodriguez M, Compte M, Cisneros E, Veguillas P, Garcia J, Dominguez G, Campos-Martin $\mathrm{Y}$, and Cuevas J. 2012. Analysis of exosome release and its prognostic value in human colorectal cancer. Genes, Chromosomes and Cancer 51:409-418.

Singh R, Pochampally R, Watabe K, Lu Z, and Mo Y-Y. 2014. Exosome-mediated transfer of miR-10b promotes cell invasion in breast cancer. Molecular cancer 13:256.

Steelman LS, Navolanic PM, Sokolosky ML, Taylor JR, Lehmann BD, Chappell WH, Abrams SL, Wong EW, Stadelman KM, and Terrian DM. 2008. Suppression of PTEN function increases breast cancer chemotherapeutic drug resistance while conferring sensitivity to mTOR inhibitors. Oncogene 27.

Stope MB, Klinkmann G, Diesing K, Koensgen D, Burchardt M, and Mustea A. 2017. Heat Shock Protein HSP27 Secretion by Ovarian Cancer Cells Is Linked to Intracellular Expression Levels, Occurs Independently of the Endoplasmic Reticulum Pathway and HSP27's Phosphorylation Status, and Is Mediated by Exosome Liberation. Disease markers 2017.

Sugimachi K, Matsumura T, Hirata H, Uchi R, Ueda M, Ueo H, Shinden Y, Iguchi T, Eguchi H, and Shirabe K. 2015. Identification of a bona fide microRNA biomarker in serum exosomes that predicts hepatocellular carcinoma recurrence after liver transplantation. British journal of cancer 112:532-538.

Sund M, and Kalluri R. 2009. Tumor stroma derived biomarkers in cancer. Cancer and Metastasis Reviews 28:177-183.

Swartz MA, lida N, Roberts EW, Sangaletti S, Wong MH, Yull FE, Coussens LM, and DeClerck YA. 2012. Tumor microenvironment complexity: emerging roles in cancer therapy. AACR.

Takahashi Y, Nishikawa M, Shinotsuka H, Matsui Y, Ohara S, Imai T, and Takakura Y. 2013. Visualization and in vivo tracking of the exosomes of murine melanoma B16-BL6 cells in mice after intravenous injection. Journal of Biotechnology 165:77-84.

Taverna S, Flugy A, Saieva L, Kohn EC, Santoro A, Meraviglia S, De Leo G, and Alessandro R. 2012. Role of exosomes released by chronic myelogenous leukemia cells in angiogenesis. International journal of cancer 130:2033-2043.

Taverna S, Fontana S, Monteleone F, Pucci M, Saieva L, De Caro V, Cardinale VG, Giallombardo M, Vicario E, and Rolfo C. 2016. Curcumin modulates chronic myelogenous leukemia exosomes composition and affects angiogenic phenotype via exosomal miR-21. Oncotarget 7:30420.

Taylor DD, and Gercel-Taylor C. 2008. MicroRNA signatures of tumor-derived exosomes as diagnostic biomarkers of ovarian cancer. Gynecologic Oncology 110:13-21.

Taylor DD, and Gercel-Taylor C. 2011. Exosomes/microvesicles: mediators of cancer-associated immunosuppressive microenvironments. Seminars in Immunopathology: Springer. p 441-454.

1026

1030

1032

1034

1037

1040

1043

1045

1046 
Théry C, Amigorena S, Raposo G, and Clayton A. 2006. Isolation and characterization of exosomes from cell culture supernatants and biological fluids. Current Protocols in Cell Biology:3.22. 21-23.22. 29.

Théry C, Zitvogel L, and Amigorena S. 2002. Exosomes: composition, biogenesis and function. Nature reviews Immunology 2:569.

Tian Y, Li S, Song J, Ji T, Zhu M, Anderson GJ, Wei J, and Nie G. 2014. A doxorubicin delivery platform using engineered natural membrane vesicle exosomes for targeted tumor therapy. Biomaterials 35:2383-2390.

Trajkovic K, Hsu C, Chiantia S, Rajendran L, Wenzel D, Wieland F, Schwille P, Brügger B, and Simons M. 2008. Ceramide triggers budding of exosome vesicles into multivesicular endosomes. Science 319:1244-1247.

Trams EG, Lauter CJ, Salem JN, and Heine U. 1981. Exfoliation of membrane ecto-enzymes in the form of micro-vesicles. Biochimica et Biophysica Acta (BBA)-Biomembranes 645:63-70.

Umezu T, Ohyashiki K, Kuroda M, and Ohyashiki J. 2013. Leukemia cell to endothelial cell communication via exosomal miRNAs. Oncogene 32:2747.

Valadi H, Ekström K, Bossios A, Sjöstrand M, Lee JJ, and Lötvall JO. 2007. Exosome-mediated transfer of mRNAs and microRNAs is a novel mechanism of genetic exchange between cells. Nature cell biology 9:654.

Vlassov AV, Magdaleno S, Setterquist R, and Conrad R. 2012. Exosomes: current knowledge of their composition, biological functions, and diagnostic and therapeutic potentials. Biochimica et Biophysica Acta (BBA)-General Subjects 1820:940-948.

Wang H, Hou L, Li A, Duan Y, Gao H, and Song X. 2014a. Expression of serum exosomal microRNA-21 in human hepatocellular carcinoma. BioMed research international 2014.

Wang J, De Veirman K, Faict S, Frassanito MA, Ribatti D, Vacca A, and Menu E. 2016. Multiple myeloma exosomes establish a favourable bone marrow microenvironment with enhanced angiogenesis and immunosuppression. The Journal of pathology 239:162-173.

Wang K, Zhang S, Weber J, Baxter D, and Galas DJ. 2010. Export of microRNAs and microRNA-protective protein by mammalian cells. Nucleic acids research 38:7248-7259.

Wang M, Zhao C, Shi H, Zhang B, Zhang L, Zhang X, Wang S, Wu X, Yang T, and Huang F. $2014 b$. Deregulated microRNAs in gastric cancer tissue-derived mesenchymal stem cells: novel biomarkers and a mechanism for gastric cancer. British journal of cancer 110:1199.

Wei Y, Lai X, Yu S, Chen S, Ma Y, Zhang Y, Li H, Zhu X, Yao L, and Zhang J. 2014. Exosomal miR-221/222 enhances tamoxifen resistance in recipient ER-positive breast cancer cells. Breast cancer research and treatment 147:423-431.

Wojtuszkiewicz A, Schuurhuis GJ, Kessler FL, Piersma SR, Knol JC, Pham TV, Jansen G, Musters RJ, van Meerloo J, and Assaraf YG. 2016. Exosomes secreted by apoptosis-resistant acute myeloid leukemia (AML) blasts harbor regulatory network proteins potentially involved in antagonism of apoptosis. Molecular \& Cellular Proteomics 15:1281-1298.

Wollert T, and Hurley JH. 2010. Molecular mechanism of multivesicular body biogenesis by ESCRT complexes. Nature 464:864.

Worst TS, von Hardenberg J, Gross JC, Erben P, Schnölzer M, Hausser I, Bugert P, Michel MS, and Boutros M. 2017. Database-augmented Mass Spectrometry Analysis of Exosomes Identifies Claudin 3 as a Putative Prostate Cancer Biomarker. Molecular \& Cellular Proteomics 16:9981008.

Wu H, Zhou J, Zeng C, Wu D, Mu Z, Chen B, Xie Y, Ye Y, and Liu J. 2016. Curcumin increases exosomal TCF21 thus suppressing exosome-induced lung cancer. Oncotarget 7:87081.

1050

1052 
Wu Y, Deng W, McGinley E, and Klinke DJ. 2015. B16F0 melanoma exosomes deliver a unique and complex biological payload that includes Ptpn11 to suppress T lymphocyte function. Journal for immunotherapy of cancer 3:P270.

Wu Y, Deng W, McGinley EC, and Klinke DJ. 2017. Melanoma exosomes deliver a complex biological payload that upregulates PTPN11 to suppress T lymphocyte function. Pigment cell \& melanoma research 30:203-218.

Xiang X, Poliakov A, Liu C, Liu Y, Deng Zb, Wang J, Cheng Z, Shah SV, Wang GJ, and Zhang L. 2009. Induction of myeloid-derived suppressor cells by tumor exosomes. International journal of cancer 124:2621-2633.

Xiao W, Dong W, Zhang C, Saren G, Geng P, Zhao H, Li Q, Zhu J, Li G, and Zhang S. 2013. Effects of the epigenetic drug MS-275 on the release and function of exosome-related immune molecules in hepatocellular carcinoma cells. European Journal of Medical Research 18:61.

Xie Y, Zhang X, Zhao T, Li W, and Xiang J. 2013. Natural CD8+ 25+ regulatory T cell-secreted exosomes capable of suppressing cytotoxic T lymphocyte-mediated immunity against B16 melanoma. Biochemical and Biophysical Research Communications 438:152-155.

Yamamoto KR, Alberts BM, Benzinger R, Lawhorne L, and Treiber G. 1970. Rapid bacteriophage sedimentation in the presence of polyethylene glycol and its application to large-scale virus purification. Virology 40:734-744.

Yamashita T, Kamada H, Kanasaki S, Maeda Y, Nagano K, Abe Y, Inoue M, Yoshioka Y, Tsutsumi Y, and Katayama S. 2013. Epidermal growth factor receptor localized to exosome membranes as a possible biomarker for lung cancer diagnosis. Die Pharmazie-An International Journal of Pharmaceutical Sciences 68:969-973.

Yang T, Martin P, Fogarty B, Brown A, Schurman K, Phipps R, Yin VP, Lockman P, and Bai S. 2015. Exosome delivered anticancer drugs across the blood-brain barrier for brain cancer therapy in Danio rerio. Pharmaceutical Research 32:2003-2014.

Yao Y, Wang C, Wei W, Shen C, Deng X, Chen L, Ma L, and Hao S. 2014. Dendritic cells pulsed with leukemia cell-derived exosomes more efficiently induce antileukemic immunities. PLoS One 9:e91463.

Yao Y, Wei W, Sun J, Chen L, Deng X, Ma L, and Hao S. 2015. Proteomic analysis of exosomes derived from human lymphoma cells. European Journal of Medical Research 20:8.

Yeung CLA, Tsuruga T, Yeung T-L, Kwan S-Y, Leung CS, Li Y, Lu ES, Kwan K, Wong K-K, and Schmandt R. 2016. Exosomal transfer of stroma-derived miR21 confers paclitaxel resistance in ovarian cancer cells through targeting APAF1. Nature communications 7:11150.

Yoon C, Kim J, Park G, Kim S, Kim D, Hur DY, Kim B, and Kim YS. 2016. Delivery of miR-155 to retinal pigment epithelial cells mediated by Burkitt's lymphoma exosomes. Tumor Biology 37:313-321.

Yu S, Cao H, Shen B, and Feng J. 2015. Tumor-derived exosomes in cancer progression and treatment failure. Oncotarget 6:37151.

Yu X, Harris SL, and Levine AJ. 2006. The regulation of exosome secretion: a novel function of the p53 protein. Cancer research 66:4795-4801.

Zaharie F, Muresan M-S, Petrushev B, Berce C, Gafencu G-A, Selicean S, Jurj A, Cojocneanu-Petric R, Lisencu C-I, and Pop L-A. 2015. Exosome-carried microRNA-375 inhibits cell progression and dissemination via Bcl-2 blocking in colon cancer. Journal of Gastrointestinal and Liver Diseases 24:435-443.

Zeringer E, Barta T, Li M, and Vlassov AV. 2015. Strategies for isolation of exosomes. Cold Spring Harbor Protocols 2015:pdb. top074476.

Zhang H-G, and Grizzle WE. 2014. Exosomes: a novel pathway of local and distant intercellular communication that facilitates the growth and metastasis of neoplastic lesions. The American journal of pathology 184:28-41. 
Zhang H, Deng T, Liu R, Bai M, Zhou L, Wang X, Li S, Wang X, Yang H, and Li J. 2017. Exosome-delivered EGFR regulates liver microenvironment to promote gastric cancer liver metastasis. Nature communications 8.

Zhao Z, Yang Y, Zeng Y, and He M. 2016. A microfluidic ExoSearch chip for multiplexed exosome detection towards blood-based ovarian cancer diagnosis. Lab on a Chip 16:489-496.
1141

1142

1143

1144

1145

1146

1147 


\section{Figure 1}

Schematic of exosomes derived cancer cell biogenesis and secretion

Exosomes can secrete through cells while intracellular organs called multivesicular bodies (MVBs) fuse with the plasma membrane. The MVBs formation occurs through invaginations of late endosomes, which increased molecules from the Golgi apparatus (e.g., MHC class II molecules) or the cell surface (e.g., growth factor receptors). Subsequently, exosomes could be enriched in several materials including sphingomyelin, intracellular protein, ceramide, cholesterol, transmembrane receptors, mRNA, and miRNA. The exosomes secreted from human tumor cells can affect the local tumor microenvironment, alter the extracellular matrix, and enhance the angiogenesis, thrombosis and cancer cell proliferation.

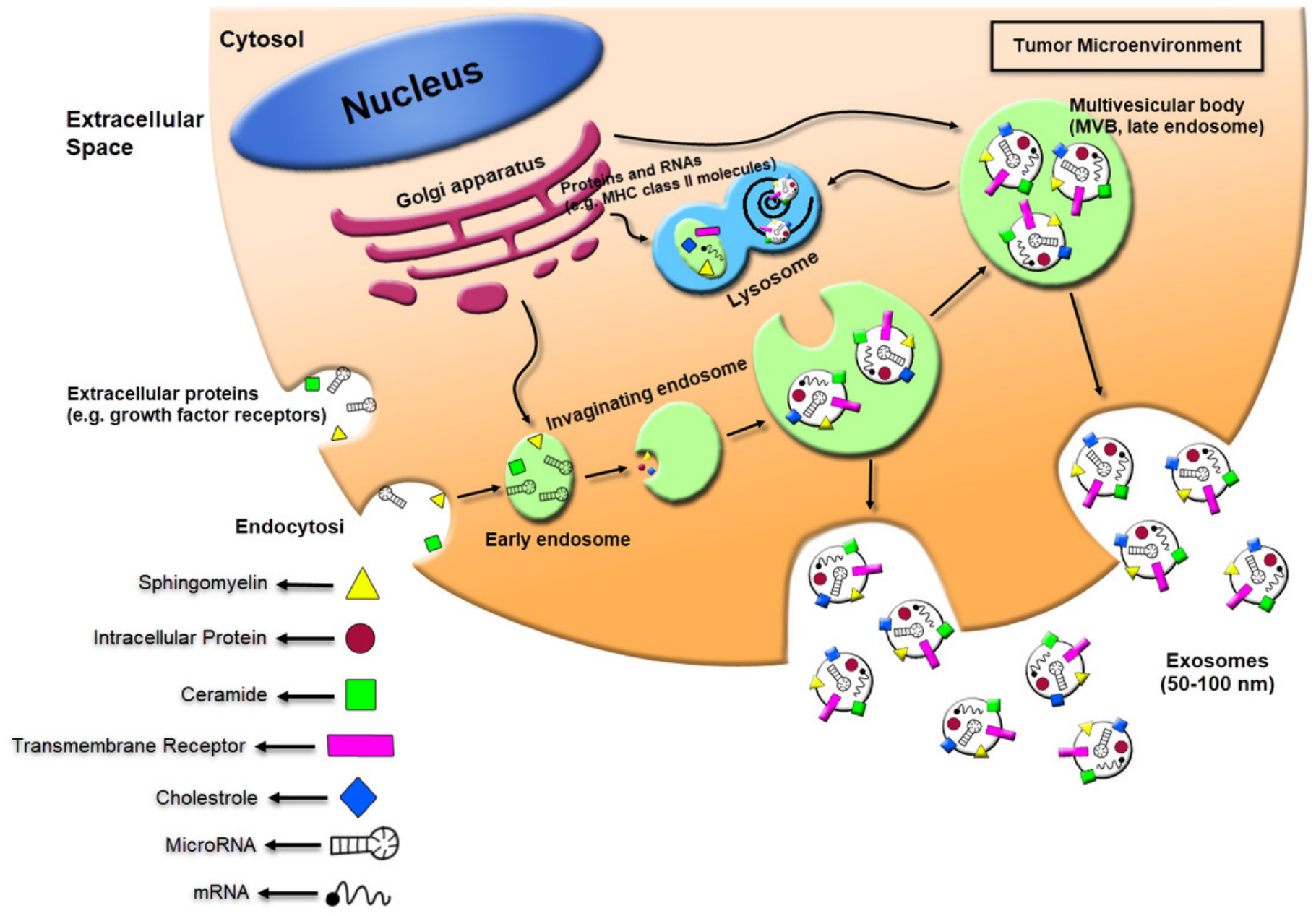




\section{Figure 2}

Exosome recruitment of bone marrow-derived cells

Exosomes transform the tumor microenvironment (TME) and dispose of distant tissue sites for metastasis. The efficacies of exosomes at distant tumor sites necessitate that exosomes migrate through the blood or lymph. They dispose tissue sites for metastasis or transform the bone marrow (BM) environment, and making a pre-metastatic niche to enhance tumor invasion and development. Thus the tumor-derived exosomes can cause recruiting bone marrow-derived cells to the tumor and pre-tumor tissue where they function as cancer development and support the multiple tumor cell expansion and development in various human cancer cells. 


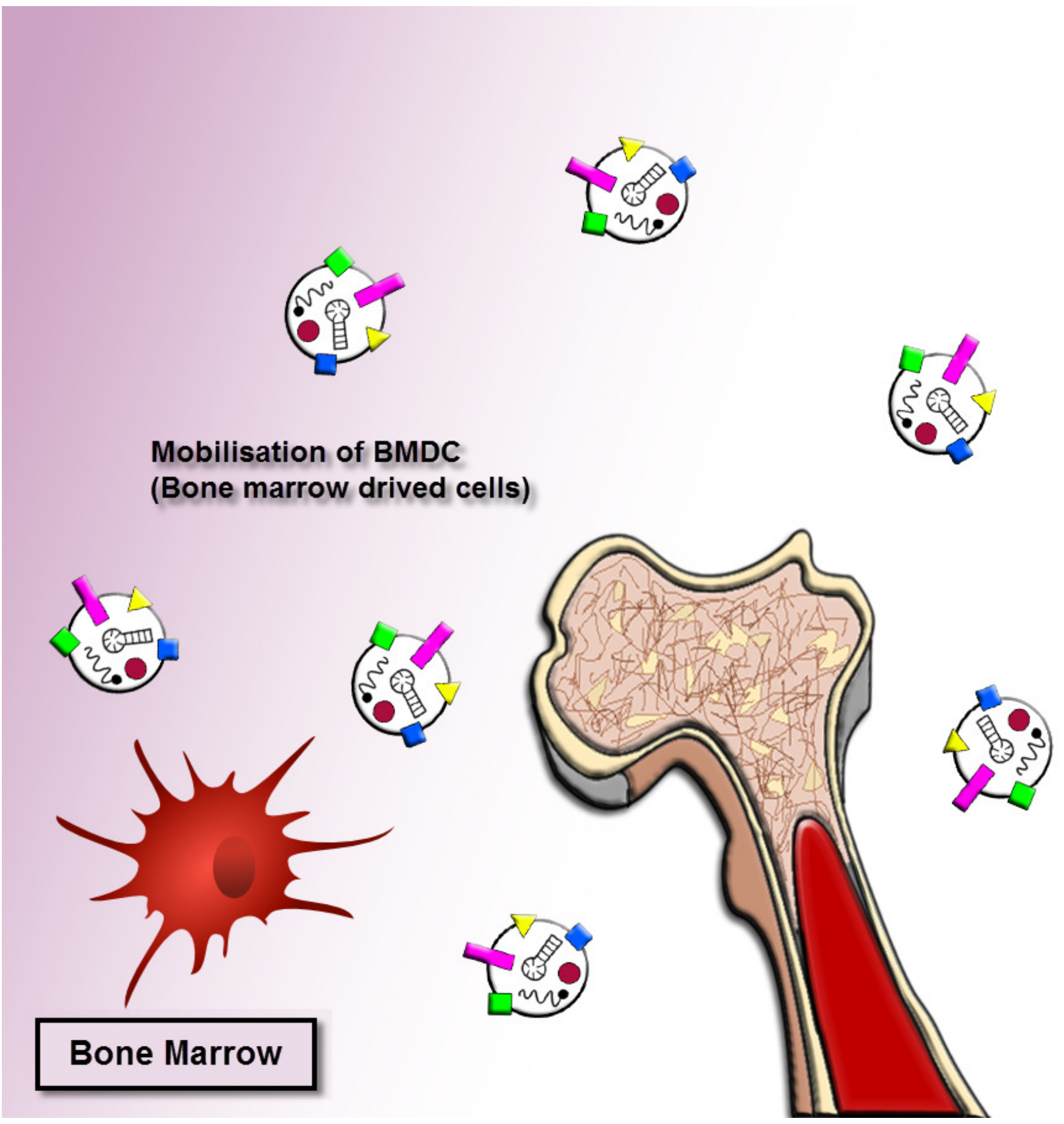




\section{Figure 3}

Exosomes drive pre-metastatic niche formation

The formation of the pre-metastatic niche is required for organ-specific metastatic tropism.

The exosomes can move to the distant location for increasing the formation of pre-metastatic niche. The complementation of angiogenesis and induction of stromal and epithelial cell differentiation can be associated with a pro-tumor environment. Tumor-derived exosomes provide a pre-metastatic niche, through the polarization of tissue macrophage, Suppression of dendritic cell maturation, Induction of CAF (cancer-associated fibroblasts) via differentiation of fibroblasts to myofibroblasts. This effect can be performed via the mediation of intercellular cross-talk and subsequent adjustment of both local and distant microenvironments in an autocrine and paracrine fashion. 
Induces M2 macrophage polarization

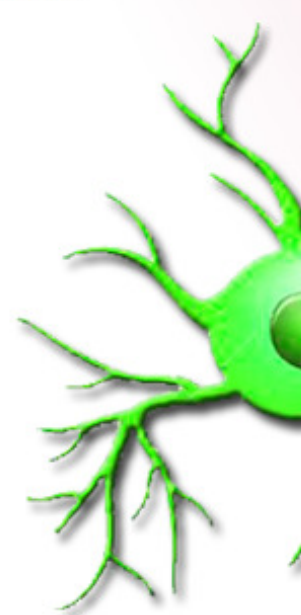

Suppress DC (dendritic cell) differentiation

\section{)}

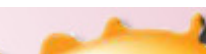

2
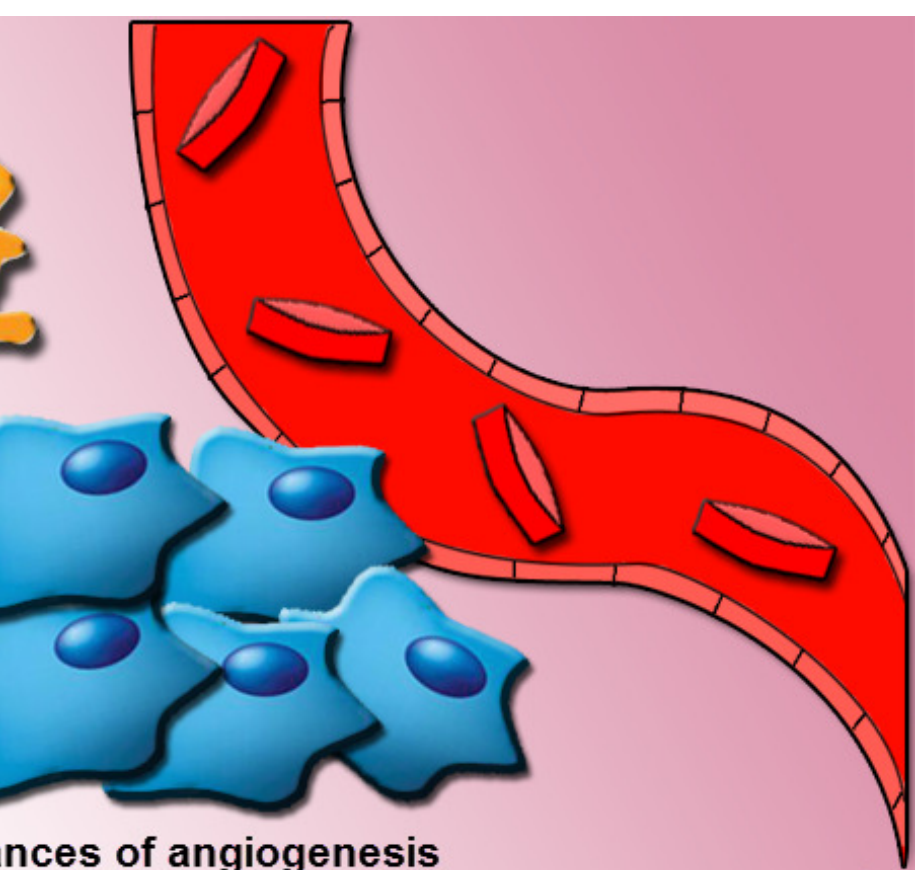

Enhances of angiogenesis and thrombosis

Induces CAF (cancer associated fibroblasts) through differentiation of fibroblasts to myofibroblasts

\section{pre-metastatic niche formation}




\section{Figure 4}

Regulation of immune responses by extracellular vesicles

The tumor-derived microvesicles may function as immunosuppressive effects. Exosomemediated communication among cancer cells and the immune system is triggered recruiting pro-cancerogenic immune cells. The regulation of immune response in a procedure of prevention tumor diagnosis and anti-tumoral immune functions through impairing the function of effector T cells and natural killer cells (NK cells), can induce mobilization of neutrophils, and differentiate T-helper cells toward a T-regulatory cell phenotype. 


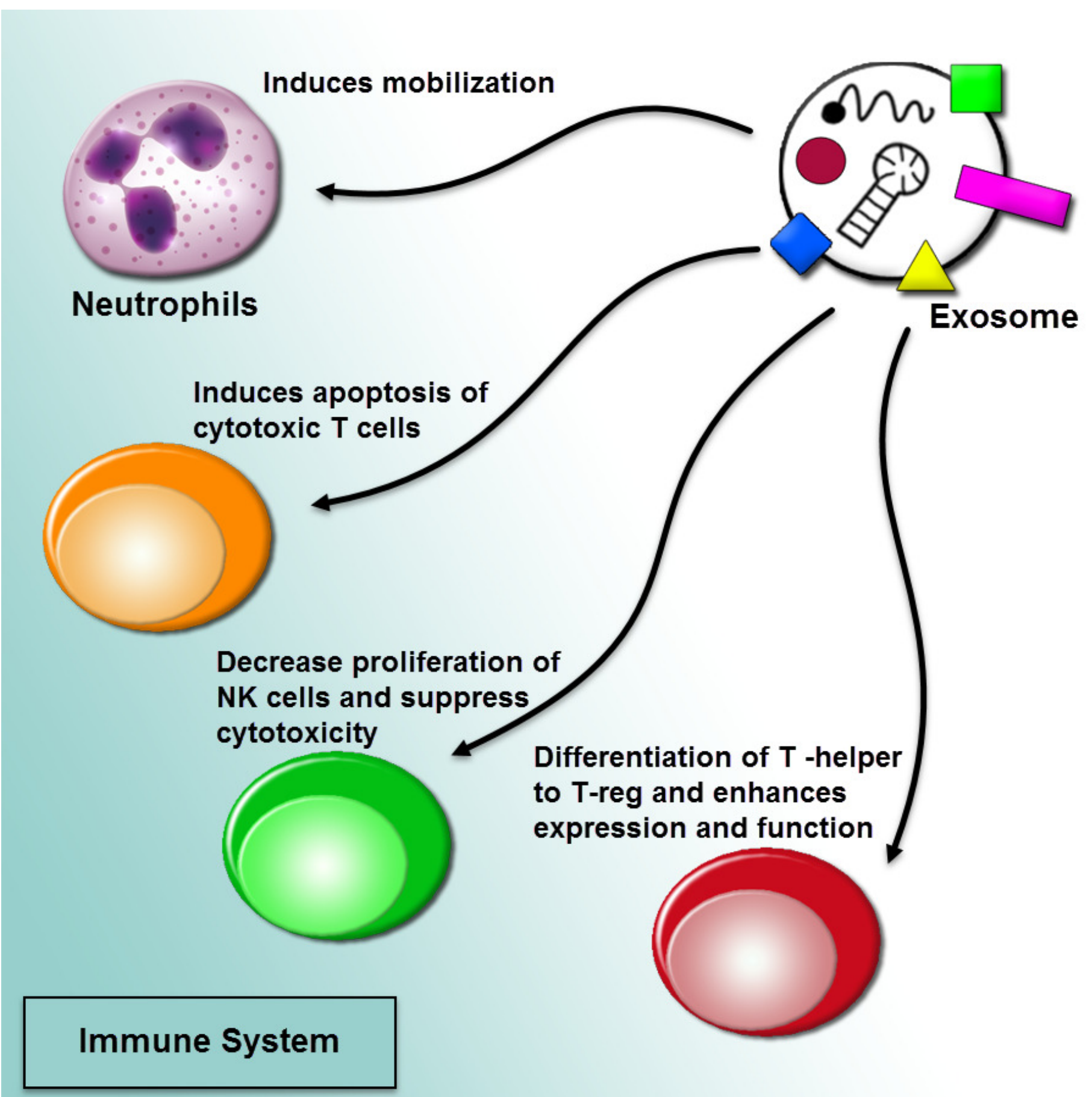




\section{Figure 5}

Exosomes as mediators of drug resistance

Drug resistance applies for a critical role in various cancer treatments. There are various mechanisms of drug resistance even multi-drug resistance (MDR) such as drug efflux, triggered by extracellular vesicles, which can make the defeat of the whole remedy. The tumor-derived exosomes can induce tumor cells to promote drug resistance through sending out the tumor drugs or inhibiting antibody-based drugs. 


\section{Drug resistance}
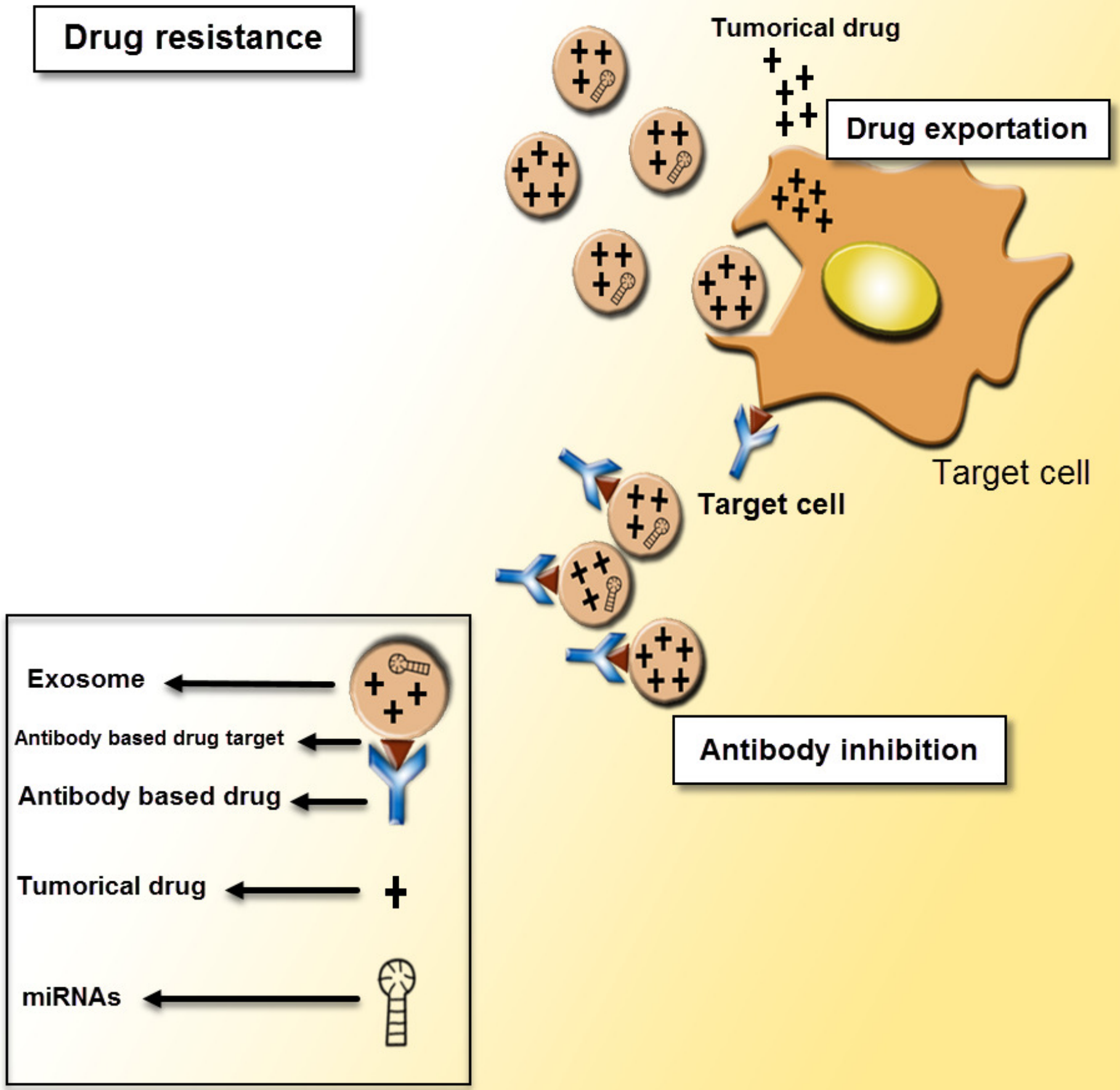


\section{Figure 6}

The main groups of exosomes based therapies

This overview includes impairing the secretion of exosomes via cancer cells and removing cancer derived exosomes, including bioactive molecules, from the blood (or other body fluids) of cancer patients; Using exosomes, naturally-equipped nanocarriers, including microRNA (miRNA), small interference RNA (siRNA), and/or anticancer drugs for targeting delivery to tumor cells; The exosomes molecular composition indicates their cells of origin, may confer special cell or tissue tropism; applying exosomes as potent cell-free peptidebased vaccine demonstrate an remarkable strategy to inhibit tumor development; exosomal miRNAs can contribute to exosome-mediated cell-cell communication and induce anticancer features. 
The greatly founding of miRNAs in exosomes originated cancer cells or isolating from bodily fluids can contribute to exosome mediated

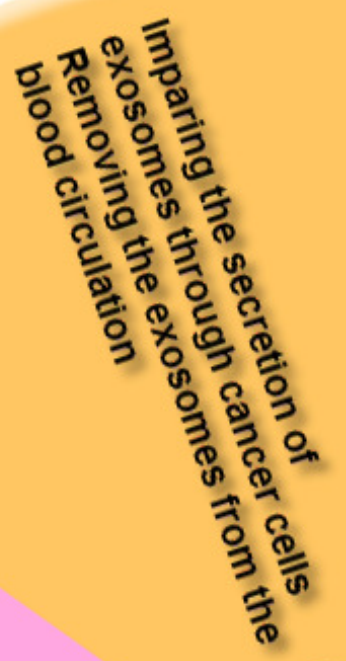
cell-cell communication, and induce anti-cancer traits
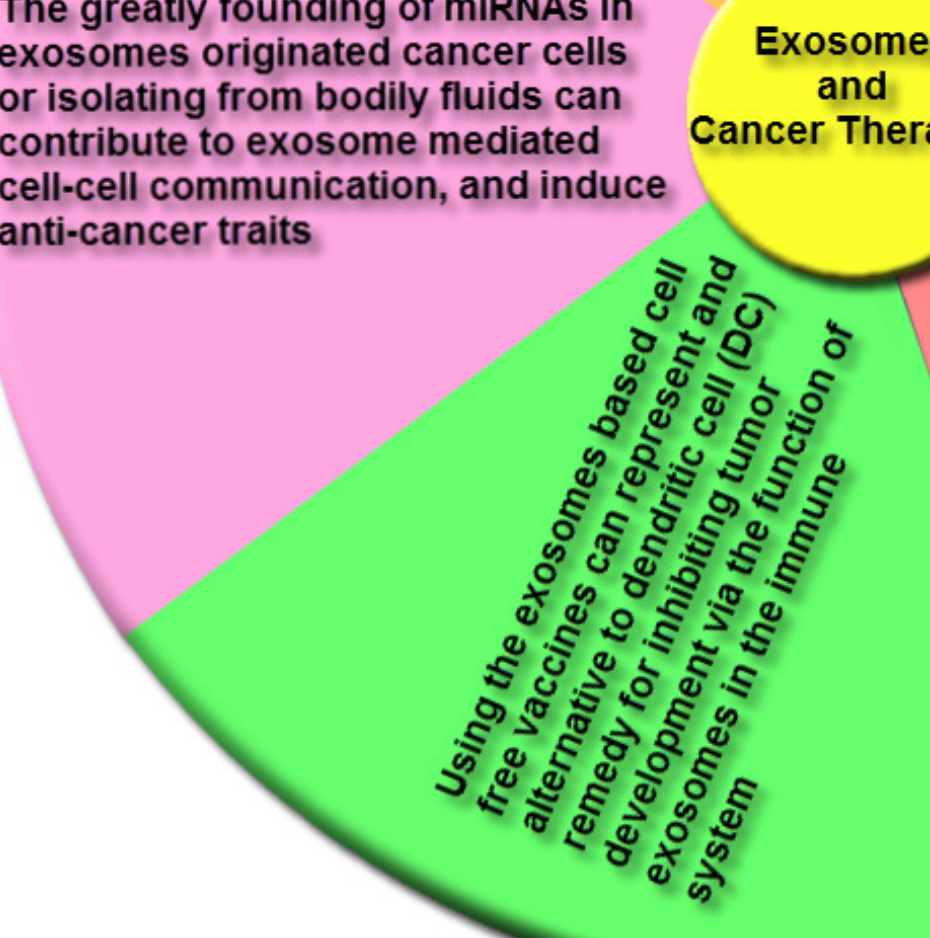

Cancer Theraphy
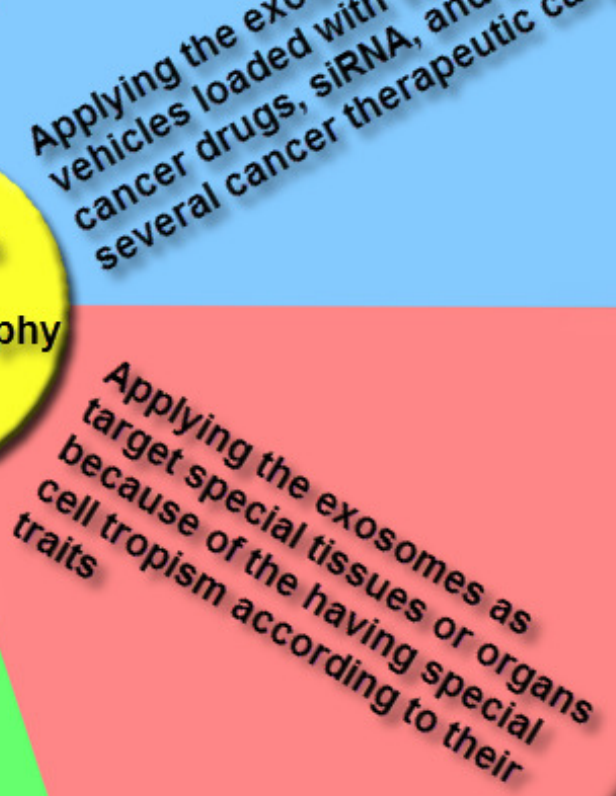
Table $\mathbf{1}$ (on next page)

Overview of the role of exosomes in cancer 


\begin{tabular}{|c|c|c|c|c|}
\hline Exosomal Cargos & Cancer Cell Types & Methods & Clinical Values & References \\
\hline ECM1, APN, APOC4, and AZGP1 & $\begin{array}{l}\text { Serum samples were collected from normal, } \\
\text { and healthy women, women with NTMnb, } \\
\text { and women with BCa-NTMnb } \\
\text { The HMLE and SUM149 cell lines }\end{array}$ & $\begin{array}{l}\text { FACS analysis, Western } \\
\text { blotting and, } \\
\text { Immunofluorescence } \\
\text { analyses }\end{array}$ & $\begin{array}{l}\text { APOC4, APN, and AZPG1 as additive factors might possibly increase } \\
\text { NTM (Bronchiectasis and nontuberculous mycobacterial disease) } \\
\text { susceptibility via the modulation of immune function and triggering } \\
\text { lipolysis. }\end{array}$ & $\begin{array}{l}\text { (Philley et al. } \\
\text { 2017) }\end{array}$ \\
\hline PEG-SMRwt-CLU peptide & $\begin{array}{l}\text { The human breast cancer cell lines MCF-7 } \\
\text { cell line, a noninvasive estrogen receptor } \\
\text { positive (ER+), and MDA-MB-231 cell line ER } \\
\text { negative } \\
\text { The MCF-10A cell line, a non-tumorigenic } \\
\text { epithelial cell line }\end{array}$ & $\begin{array}{l}\text { Exosomes characterization } \\
\text { by acetylcholinesterase } \\
\text { (AchE) assay, Exosome } \\
\text { nanoparticles tracking } \\
\text { analysis (NTA), and Western } \\
\text { blotting }\end{array}$ & $\begin{array}{l}\text { The SMR peptide inhibited breast cancer cell growth, reduced } \\
\text { exosome secretion without increasing the cytotoxic effects of } \\
\text { chemotherapy or promoting apoptosis. }\end{array}$ & $\begin{array}{l}\text { (Huang et al. } \\
\text { 2017) }\end{array}$ \\
\hline MiR-10b & $\begin{array}{l}\text { The human breast cancer cell lines MCF-7 } \\
\text { and MDA-MB- } 231 \text { cells } \\
\text { The human mammary epithelial cell lines } \\
\text { MCF-10A, and HMLE cells } \\
\text { The human embryonic kidney cell line HEK- } \\
\text { 293T cells }\end{array}$ & $\begin{array}{l}\text { qRT-PCR analysis, and } \\
\text { Western blotting }\end{array}$ & $\begin{array}{l}\text { MiR-10b as an exosomal miRNA that elevated cell invasion in HMLE } \\
\text { cells through targeting HOXD10 and KLF4, indicating the invasive } \\
\text { tumor cells may utilize exosomal miRNAs as a means for their } \\
\text { advance. }\end{array}$ & (Singh et al. 2014) \\
\hline $\begin{array}{l}\text { MiR-198, MiR-26a, MiR-34a, MiR- } \\
\text { 49a, let-7a, MiR-328, MiR130a, MiR- } \\
\text { 149, MiR-602, MiR-92b }\end{array}$ & $\begin{array}{l}\text { The human breast cancer cell lines, culture } \\
\text { supernatants from MCF7, and MDA-MB231 } \\
\text { cells }\end{array}$ & $\begin{array}{l}\text { qRT-PCR analysis, and } \\
\text { Western blotting }\end{array}$ & $\begin{array}{l}\text { The extracellular vesicles carry oncogenic proteins and miRNAs, } \\
\text { which may further be applicable for early detection of breast } \\
\text { malignancy as well as delineating the possible role of extracellular } \\
\text { vesicles in tumorigenesis and metastasis. }\end{array}$ & $\begin{array}{l}\text { (Kruger et al. } \\
\text { 2014) }\end{array}$ \\
\hline C6 Ceramide & $\begin{array}{l}\text { The human breast cancer cell line MDA-MB } \\
231 \text { cells }\end{array}$ & $\begin{array}{l}\text { qRT-PCR analysis, and } \\
\text { Immunocytochemistry assay }\end{array}$ & $\begin{array}{l}\text { Exogenous C6 ceramide, a sphingolipid known to induce exosome } \\
\text { secretion, also induced secretion of BCRP-associated exosomes, while } \\
\text { siRNA-mediated knockdown or GW4869-mediated inhibition of } \\
\text { neutral sphingomyelinase } 2 \text { (nSMase2), an enzyme generating } \\
\text { ceramide, restored cellular BCRP. }\end{array}$ & (Kong et al. 2015) \\
\hline HCV RNA (exoRNA) & $\begin{array}{l}\text { The human breast cancer cell lines (IRDs } \\
\text { Responders) 1833, MDA-MB-231, Hs578T, } \\
\text { MDA-MB-436, MDA-MB-157, and HCC1937 } \\
\text { The human breast cancer cell lines (IRDs } \\
\text { non-Responders) SKBR3, T47D, MCF-7, } \\
\text { HCC70, and MDA-MB-468 }\end{array}$ & $\begin{array}{l}\text { Chromatin } \\
\text { immunoprecipitation and } \\
\text { primary transcript analysis, } \\
\text { and Mammosphere analysis }\end{array}$ & $\begin{array}{l}\text { Stromal cells orchestrate an intricate cross-talk with BrCa cells by } \\
\text { utilizing exosomes to instigate anti-viral signaling. This expands BrCa } \\
\text { subpopulations adept at resisting therapy and re-initiating tumor } \\
\text { growth. }\end{array}$ & $\begin{array}{l}\text { (Boelens et al. } \\
\text { 2014) }\end{array}$ \\
\hline
\end{tabular}




\begin{tabular}{|c|c|c|c|c|}
\hline $\begin{array}{l}\text { Hsp70 (an exosomal protein } \\
\text { marker) }\end{array}$ & $\begin{array}{l}\text { The epithelial like breast cancer cell line } \\
\text { MDA MB- } 231 \text { cells }\end{array}$ & $\begin{array}{l}\text { qRT-PCR analysis, and } \\
\text { Western blotting }\end{array}$ & $\begin{array}{l}\text { The EXO/SEB, two immune inducer substances, was able to induce } \\
\text { cytostatic events through apoptosis in insensitive human ER- breast } \\
\text { cell line. The EXO/SEB considerably decreased the cell proliferation } \\
\text { and stimulated apoptosis via increasing the expression level of bak, } \\
\text { and bax, and raised the activity of caspase- } 3 \text { and caspase- } 9 \text {. }\end{array}$ & $\begin{array}{l}\text { (Hosseini et al. } \\
\text { 2014) }\end{array}$ \\
\hline $\begin{array}{l}\text { RPL27A, GDF11, EPS15L1, NUDT16, } \\
\text { TRAK2, CCDC11, BEND6, ZNF114, } \\
\text { IFNAR1, PITPNM3, ENSA, ALKBH7, } \\
\text { APLP2, VAPA, SNRPB, SAR1B, } \\
\text { DCAF16, FAM134B, GJC1, and } \\
\text { MSLN }\end{array}$ & $\begin{array}{l}\text { The human metastatic mammary gland } \\
\text { epithelial adenocarcinoma cell line MDA-MB- } \\
\text { 231, and human submandibular gland (HSG) } \\
\text { cells }\end{array}$ & Western blot analysis & $\begin{array}{l}\text { The breast cancer-derived exosome-like microvesicles are capable of } \\
\text { interacting with salivary gland cells, altering the composition of their } \\
\text { secreted exosome-like microvesicles. }\end{array}$ & $\begin{array}{l}\text { (Lau \& Wong } \\
\text { 2012) }\end{array}$ \\
\hline OIP2 & $\begin{array}{l}\text { The human breast cancer cell lines MDA-MB- } \\
231 \text { cells, and MCF- } 7 \text { cells }\end{array}$ & $\begin{array}{l}\text { qRT-PCR analysis, and } \\
\text { Enzyme-linked } \\
\text { Immunosorbent Assay } \\
\text { (ELISA) }\end{array}$ & $\begin{array}{l}\text { Monad-mediated degradation is one of the mechanisms that } \\
\text { determine the stability of amphiregulin mRNA and that Monad- } \\
\text { amphiregulin axis plays an essential role in the invasion of breast } \\
\text { cancer cells. }\end{array}$ & (Saeki et al. 2013) \\
\hline Wnt10b & $\begin{array}{l}\text { The immortalized WT mouse embryonic } \\
\text { fibroblasts (MEFs) and the p } 85 \alpha-/- \\
\text { MEFs } \\
\text { The human breast cancer cell line MDA-MB- } \\
231 \\
\text { The mouse breast cancer cell line } 4 \mathrm{~T} 1\end{array}$ & $\begin{array}{l}\text { qRT-PCR analysis, and } \\
\text { Western blotting }\end{array}$ & $\begin{array}{l}\text { Paracrine Wnt10b from p } 85 \alpha \text {-deficient fibroblasts can promote } \\
\text { cancer progression via EMT induced by the canonical Wnt pathway. } \\
\text { Moreover, exosomes have a key role in paracrine Wnt10b transport } \\
\text { from fibroblasts to breast cancer epithelial cells. Thus p85 } \alpha \\
\text { expression in stromal fibroblasts has a pivotal role in regulating } \\
\text { breast cancer tumorigenesis and progression. }\end{array}$ & (Chen et al. 2017) \\
\hline ERG, PCA3, and SPDEF & $\begin{array}{l}\text { The urine samples of prostate cancer (PCA)- } \\
\text { free men } 50 \text { years or older } \\
\text { The urine samples of Men with a history of } \\
\text { invasive treatment for benign prostatic } \\
\text { disease }\end{array}$ & qRT-PCR analysis & $\begin{array}{l}\text { The ExoDx Prostate IntelliScore is a validated, easy to administer, } \\
\text { noninvasive urine exosome gene expression assay gene signature is } \\
\text { derived from genes known to play a pivotal role in prostate cancer } \\
\text { initiation and development including ERG, PCA3, and SPDEF with the } \\
\text { potential to decrease the total number of biopsies performed in men } \\
\text { with a suspicion of prostate cancer. }\end{array}$ & $\begin{array}{l}\text { (McKiernan et al. } \\
\text { 2016) }\end{array}$ \\
\hline $\begin{array}{l}\text { Paclitaxel (PtX), a widely used } \\
\text { antimitotic cancer therapeutic }\end{array}$ & $\begin{array}{l}\text { The human prostate cancer cell lines LNCaP } \\
\text { and PC-3 PCa cells }\end{array}$ & $\begin{array}{l}\text { Nanoparticle tracking } \\
\text { analysis (NTA), and Western } \\
\text { blotting }\end{array}$ & $\begin{array}{l}\text { Cancer cell-derived EVs can be utilized as beneficial carriers of } \\
\text { Paclitaxel to their parental cells, bringing the drug into the cells via } \\
\text { an endocytic pathway and promoting its cytotoxicity. Thus, } \\
\text { autologous EVs may have potential for effective delivery of } \\
\text { chemotherapeutics to cancer cells. }\end{array}$ & (Saari et al. 2015) \\
\hline Claudin 3 (CLDN3) & $\begin{array}{l}\text { The human metastatic PC3 and benign } \\
\text { PNT1A prostate cell lines } \\
\text { The blood plasma of patients with prostate } \\
\text { cancer }\end{array}$ & $\begin{array}{l}\text { Immunoblotting, Enzyme- } \\
\text { linked immunosorbent assay } \\
\text { (ELISA), and Western } \\
\text { blotting }\end{array}$ & $\begin{array}{l}\text { CLDN3 is an exemplary exosome-based circulating biomarker which } \\
\text { candidate for prostate cancer from in vitro profiling of cancer } \\
\text { exosomes over in silico identification and in vitro retesting to clinical } \\
\text { validation. Besides, CLDN3 plasma levels were considerably } \\
\text { increased in patients with high Gleason score, pointing to a potential } \\
\text { predictive value of this marker. }\end{array}$ & $\begin{array}{c}\text { (Worst et al. } \\
\text { 2017) }\end{array}$ \\
\hline
\end{tabular}


B7-H3 (CD276)

The immunomodulatory cytokine IL-6, and the

pro-angiogenic factors IL-8, VEGF, and MMP2

Histones (H2A, H2B, H3.1 and H4), heat shock proteins

(he

tetraspanin CD81

$-$

CD9, CD63, CD81, Cluster 1 (MiR216a, MiR-217, MiR-129-5p, and MiR-203), Cluster 2 (MiR-9, MiR125a-5p, MiR-25, MiR-125b, MiR335, and MiR-19a), Cluster 3 (MiR370, MiR-210, MiR-320a, MiR-124, MiR-107, and MiR-486-5p)

MAGE A3 (168-176) / class I, MAGE A3 (247-258) / class II, tetanus toxoid / class II, MAGE A3 (168-

176) / class I, MAGE A3 (247-258) class II, MAGE A3 (168-176) / class I, MAGE A3 (247-258) / class

II, tetanus toxoid / class II, MAGE

A3 (168-176) / class I MAGE A3

(247-258) / class II
The human prostate cancer cell lines The irrespon-responsive:

Normal human dermal fibroblasts (NHDF)

The malignant melanoma cell lines, Mewo, SKmel28, A2058, A375, and HTB63 (HT-144)

MS1 murine endothelial cells

The C57BL/6 derived melanoma cell lines B16-F1, and B16-OVA (B16-F0 cell line

The C57BL/6 derived thymoma derived EL4 cell line

Metastatic melanoma cell lines Me 30966

The blood plasma samples of patients with isolated liver metastases from uveal melanoma

The human malignant melanoma cell lines A375, and MML-1

The human breast cancer cell line, HTB-133 The human lung carcinoma cell line, HTB177

The human mast cell line, HMC-1.2

Fifteen patients bearing melanoma (stage IIIB and IV, HLA-A1+, or -B35+ and HLADPO4+ leukocyte phenotype, tumor

expressing MAGE3 antigen)
Western Blot Analysis

qRT-PCR analysis, Enzyme-
linked immunosorbent assay

(ELISA), and Western

blotting

Flow cytometric analyses, and Western blotting Extracellular vesicles (EV) have been implicated in thrombotic events vesicles contribute to the anti-cancer immune response.

The release of exosome-like microvesicles can promote during proliferative senescence in normal human diploid fibroblasts. Moreover, these exosomes were enriched in $\mathrm{B} 7-\mathrm{H} 3$ protein, a recently identified diagnostic marker for prostate cancer and an abundance of exosomal shuttle RNA.

The non-canonical Wht protein WNT5A signaling, induces a Ca2+dependent release of exosomes containing the immunomodulatory and pro angiogenic proteins IL-6, IL-8, VEGF, and MMP2 in melanom cells.

Sharafaldine et al.

Flow cytometric analyses,

The enhanced drug delivery time of Exo-AO to melanoma cells as compared to the free AO, improving the cytotoxicity of AO. Thus, Exo$\mathrm{AO}$ have a great potential for a real exploitation as a novel theranostic approach against tumors based on AO delivered through the exosomes.

Flow cytometry assay, qRTPCR analysis, and Western blotting

Melanoma exosomes are released into the liver circulation in metastatic uveal melanoma, and is associated with higher concentrations of exosomes in the systemic circulation. The exosomes isolated directly from liver circulation contain miRNA clusters that are different from exosomes from other cellular sources.

Flow cytometry assay, qRTlinked immunosorbent assay variant suggested that exosomes mediated bioactivity in vivo, supporting to conduct Phase II clinical trials. Thus, the first exosome Phase I trial highlighted the possibility of large scale exosome production and the safety of exosome administration.
(Ekström et al.

(Muhsin-

2016)

(Eldh et al. 2014)

Lehmann et al. 2008)

(Iessi et al. 2017)

(Escudier et al. 2005) 


\begin{tabular}{|c|c|c|c|c|}
\hline $\begin{array}{l}\text { Housekeeping proteins (CD63 and } \\
\text { Rab-5b) and a tumor-associated } \\
\text { marker (caveolin-1) }\end{array}$ & $\begin{array}{l}\text { The human metastatic melanoma cell lines } \\
\text { Me501, and MeBS cells } \\
\text { The osteosarcoma (SaOS-2) and colon } \\
\text { carcinoma cell lines } \\
\text { The blood plasma samples of melanoma } \\
\text { patients }\end{array}$ & $\begin{array}{l}\text { Flow cytometry assay, } \\
\text { Enzyme-linked } \\
\text { immunosorbent assay } \\
\text { (ELISA), and Western } \\
\text { blotting }\end{array}$ & $\begin{array}{l}\text { Plasma exosomes expressing CD63 or caveolin-1 were significantly } \\
\text { promoted in melanoma patients as compared to healthy donors. } \\
\text { Moreover, caveolin-1+ plasma exosomes were remarkably increased } \\
\text { with respect to CD } 63+\text { exosomes in the patients group. }\end{array}$ & $\begin{array}{l}\text { (Logozzi et al. } \\
\text { 2009) }\end{array}$ \\
\hline MiR-21, MiR-34 a, and MiR-146a & $\begin{array}{l}\text { The blood serum sampling of Uveal } \\
\text { melanoma (UM) patients and healthy donors }\end{array}$ & $\begin{array}{l}\text { Flow cytometry assay, and } \\
\text { qRT-PCR analysis }\end{array}$ & $\begin{array}{l}\text { MiRNAs differentially expressed in UM patients comparing with } \\
\text { healthy donors. Most alterations were common to vitreous humor } \\
\text { (VH), and vitreal exosomes (upregulation of miR- } 21,-34 \text { a,- } 146 \mathrm{a} \text { ). } \\
\text { Interestingly, miR-146a, miR-34a, and miR-146a were upregulated in } \\
\text { the serum of UM patients, as well as in serum exosomes. }\end{array}$ & $\begin{array}{l}\text { (Ragusa et al. } \\
\text { 2015) }\end{array}$ \\
\hline $\begin{array}{l}\text { Tyrosinase related } \\
\text { protein-2 (TYRP2), very late } \\
\text { antigen } 4 \text { (VLA-4), heat shock } \\
\text { protein } 70 \text { (HSP70), an } \\
\text { HSP90 isoform, and MET } \\
\text { oncoprotein }\end{array}$ & $\begin{array}{l}\text { The human peripheral blood samples of } \\
\text { melanoma patients } \\
\text { 8-10 week-old C57Bl/6 female mice } \\
\text { The human breast cancer cell lines MCF-7, } \\
\text { SkBr3, and MDA-MB-231 } \\
\text { The cellosaurus cell line AsPC-1 } \\
\text { The Lewis Lung carcinoma cell line LLC } \\
\text { The colon carcinoma cell lines SW480, and } \\
\text { SW620 } \\
\text { The human melanoma cell lines B16-F10, } \\
\text { and B16-F1 }\end{array}$ & $\begin{array}{l}\text { Flow cytometry assay, qRT- } \\
\text { PCR analysis, and Western } \\
\text { blotting }\end{array}$ & $\begin{array}{l}\text { Decreasing Met expression in exosomes reduced the pro-metastatic } \\
\text { behavior of BM cells. Interestingly, MET expression was increased in } \\
\text { circulating CD } 45^{-C} \text {-KIT'low/+TIE2 } 2^{+} \text {BM progenitors from metastatic } \\
\text { melanoma subjects. RAB1a, RAB5b, RAB7, and RAB27a were highly } \\
\text { expressed in melanoma cells and Rab27a RNA interference } \\
\text { diminished exosome production, preventing BM education, tumor } \\
\text { growth and metastasis. }\end{array}$ & $\begin{array}{l}\text { (Peinado et al. } \\
\text { 2012) }\end{array}$ \\
\hline $\begin{array}{l}\text { Superparamagnetic iron oxide } \\
\text { nanoparticles } 5 \text { (SPION5) }\end{array}$ & $\begin{array}{l}\text { The C57BL/6 mouse model } \\
\text { The mouse B16-F10 (CRL 6475) melanoma } \\
\text { cells }\end{array}$ & MRI analysis & $\begin{array}{l}\text { The melanoma exosomes appear to be trafficking to a particular } \\
\text { microanatomical destination in lymph nodes known as the } \\
\text { subcapsular sinus. Thus, SPION5 loaded exosomes might be } \\
\text { particularly tailored through endogenous molecular cell based } \\
\text { nanofactories and/or exogenous synthetic exosome modification to } \\
\text { simultaneously detect and treat pathogenic microenvironments. }\end{array}$ & $\begin{array}{l}\text { (Peinado et al. } \\
\text { 2016) }\end{array}$ \\
\hline $\begin{array}{l}\text { Stabilin } 1 \text { (MS-1), Ephrin R } \beta 4 \text {, } \\
\text { Integrin } \alpha \mathrm{v} \beta 3 \text {, MAPK 14, urokinase } \\
\text { plasminogen activator (uPA), } \\
\text { laminin 5, collagen } 18, \mathrm{G}-\alpha 13, \\
\text { VEGF-B, Increased hypoxia } \\
\text { inducible factor } 1 \alpha \text { (HIF1- } \alpha \text { ), } \\
\text { thrombospondin } 1 \text { (Thbs1), Tumor } \\
\text { microenvironment associated } \\
\text { tumor necrosis factor } \alpha \text { (TNF- } \alpha \text { ) }\end{array}$ & $\begin{array}{l}\text { The mouse B16-F10 (CRL 6475) melanoma } \\
\text { cells } \\
\text { Male 6- to 8-week old albino C57/BL6 mice }\end{array}$ & qRT-PCR analysis & $\begin{array}{l}\text { Melanoma exosomes are capable of directly tuning a remote lymph } \\
\text { node toward a microenvironment that facilitates melanoma growth } \\
\text { and metastasis in lymph nodes even in the local absence of tumor } \\
\text { cells. }\end{array}$ & (Hood et al. 2011) \\
\hline
\end{tabular}




\begin{tabular}{|c|c|c|c|c|}
\hline PTPN11 & $\begin{array}{l}\text { Eight- to 12-week-old transgenic B6.Cg- } \\
\text { Thy1a/Cy Tg (TcraTcrb)8Rest/J female mice } \\
\text { The murine melanoma cell lines B16F0, } \\
\text { Cloudman S91 (clone M-3), and CTLL-2 cells } \\
\text { An immortalized mouse melanocyte cell line, } \\
\text { Melan-A cells } \\
\text { The TH1 cell model, 2D6 cells }\end{array}$ & $\begin{array}{l}\text { Flow cytometry assay, qRT- } \\
\text { PCR analysis, and Western } \\
\text { blotting }\end{array}$ & $\begin{array}{l}\text { The tumor-derived exosomes can upregulate PTPN11, which is a } \\
\text { phosphatase involved in immune checkpoint pathways, to suppress T } \\
\text { cell proliferation and are sized to accumulate within the tumor } \\
\text { microenvironment. }\end{array}$ & (Wu et al. 2017) \\
\hline Fatty acid oxidation (FAO) & $\begin{array}{l}\text { The murine 3T3-F442A preadipocyte line } \\
\text { Eight week old C57BL/6J male mice } \\
\text { The human adipose tissue samples } \\
\text { The human melanoma cell line SK-MEL-28 } \\
\text { The human metastatic melanoma cell line } \\
\text { 1205lu }\end{array}$ & $\begin{array}{l}\text { Nano-LC MS/MS analysis, } \\
\text { and Western blotting }\end{array}$ & $\begin{array}{l}\text { The adipocyte exosomes stimulate melanoma cell migration and } \\
\text { invasion. These exosomes, particularly enriched in proteins } \\
\text { implicated in fatty acid oxidation (FAO), induce metabolic } \\
\text { reprogramming in tumor cells in favor of FAO, enhancing } \\
\text { aggressiveness. }\end{array}$ & (Lazar et al. 2016) \\
\hline- & $\begin{array}{l}\text { The B16-BL6 murine melanoma cell line } \\
\text { Five-week-old male C57BL/6 and BALB/c } \\
\text { mice }\end{array}$ & $\begin{array}{l}\text { qRT-PCR analysis, and } \\
\text { Dynamic light scattering, zeta } \\
\text { potential assay }\end{array}$ & $\begin{array}{l}\text { Through designing a fusion protein con-sisting of Gaussia luciferase } \\
\text { and a truncated lactadherin, gLuc-lactadherin, and constructing a } \\
\text { plasmid expressing the fusion protein, sequential in vivo imaging } \\
\text { indicated that the B16-BL6 exosome-derived signals distributed first } \\
\text { to the liver and then to the lungs which is helpful for tracing } \\
\text { exosomes in vivo and that B16-BL6 exosomes. }\end{array}$ & $\begin{array}{c}\text { (Takahashi et al. } \\
\text { 2013) }\end{array}$ \\
\hline LAMP-1, and CD9 & $\begin{array}{l}\text { The female C57BL/ } 6 \text { mice } \\
\text { The highly lung metastatic OVA expressing } \\
\text { B16 melanoma cell line BL6-10 } \\
\text { The naive CD8+ T cells and ovalbumin } \\
\text { (OVA)-pulsed splenic dendritic } \\
\text { cells (DC } \mathrm{DCA}_{\mathrm{OVA}} \text { ) }\end{array}$ & $\begin{array}{l}\text { Flow cytometry assay, } \\
\text { Enzyme-linked } \\
\text { immunosorbent assay } \\
\text { (ELISA), and Western } \\
\text { blotting }\end{array}$ & $\begin{array}{l}\text { The natural CD8+25+ Tr cell-secreted EXOs are capable of } \\
\text { suppressing in vivo DC-induced CTL responses and antitumor } \\
\text { immunity, indicating that CD8+25+ Tr-released exosomal molecules } \\
\text { may play a pivotal role in Tr cell-mediated immune suppression. } \\
\text { CD4+25+ Tr cell suppression has been found to be related with cell- } \\
\text { surface inhibitory LAG-3, Gal- } 1 \text {, Nrp- } 1 \text { and TIGI molecules. }\end{array}$ & (Xie et al. 2013) \\
\hline- & $\begin{array}{l}\text { The C57BL/ } 6 \text { female mice and CD } 45.2+\text { OT-I } \\
\text { transgenic female mice ( } 8 \text { to } 12 \text { weeks of } \\
\text { age) } \\
\text { The CD } 45.1+\text { C57BL/6-Ly5.1 female mice ( } 8 \\
\text { to } 12 \text { weeks of age) }\end{array}$ & $\begin{array}{l}\text { Flow cytometry assay, } \\
\text { Enzyme-linked } \\
\text { immunosorbent assay } \\
\text { (ELISA), and Western } \\
\text { blotting }\end{array}$ & $\begin{array}{l}\text { The therapeutic vaccination targeted to the tumor-draining lymph } \\
\text { nodes (tdLNs) of B16F10 melanoma-bearing mice with Dexo released } \\
\text { by DCs co-cultured with oxidized necrotic B16F10 cells as source of } \\
\text { melanoma antigens and matured with poly (I:C) (Dexo (B16 + pIC)) } \\
\text { raised both melanoma-specific effector CD8+ T cells in the tdLNs, } \\
\text { spleen and tumor mass and tumor-infiltrating NK and NK-T cells, } \\
\text { significantly reducing tumor growth and increasing the survival rate } \\
\text { of diseased mice. }\end{array}$ & $\begin{array}{c}\text { (Damo et al. } \\
\text { 2015) }\end{array}$ \\
\hline
\end{tabular}




\begin{tabular}{|c|c|c|c|c|}
\hline cisplatin (CisPt) & $\begin{array}{l}\text { The human breast cancer cell line MCF7 } \\
\text { The human metastatic melanoma cell lines } \\
\text { Me30966and Me501 } \\
\text { The human colon carcinoma cell line SW480 } \\
\text { The Human PBMC (Peripheral Blood } \\
\text { Mononuclear Cells) } \\
\text { Female CB.17 SCID/SCID mice aged 4-5 } \\
\text { weeks }\end{array}$ & $\begin{array}{l}\text { Enzyme-linked } \\
\text { immunosorbent assay } \\
\text { (ELISA) }\end{array}$ & $\begin{array}{l}\text { CisPt uptake by human tumor cells was markedly impaired by low } \mathrm{pH} \\
\text { conditions. Moreover, exosomes purified from supernatants of these } \\
\text { cell cultures contained various amounts of CisPt, which correlated to } \\
\text { the pH conditions of the culture medium. }\end{array}$ & $\begin{array}{c}\text { (Federici et al. } \\
\text { 2014) }\end{array}$ \\
\hline MiR-21 & $\begin{array}{l}\text { The imatinib-sensitive CML cell lines K562-s, } \\
\text { and LAMA84-s } \\
\text { The human Umbilical Vein Endothelial Cells } \\
\text { (HUVEC) }\end{array}$ & $\begin{array}{l}\text { qRT-PCR analysis, Flow } \\
\text { cytometry assay, Enzyme- } \\
\text { linked immunosorbent assay } \\
\text { (ELISA), and Western } \\
\text { blotting }\end{array}$ & $\begin{array}{l}\text { The exosomes released by chronic myelogenous leukemia (CML) cells } \\
\text { after Curcumin remedy deeply changed their molecular composition, } \\
\text { acquiring antiangiogenic properties. Curcu-exosomes were enriched } \\
\text { in miR-21 which was then shuttled in endothelial cells as a } \\
\text { biologically active form. }\end{array}$ & $\begin{array}{c}\text { (Taverna et al. } \\
\text { 2016) }\end{array}$ \\
\hline $\begin{array}{l}\text { ALIX/PDCD6IP, TSG101,HLA-DR, } \\
\text { RAB5A, CD63, CD81, MiR-21, MiR- } \\
\text { 155, MiR-146a, MiR-148a, and let- } \\
\text { 7g, human leukocyte antigen (HLA)- } \\
\text { DR molecules, B cell-specific } \\
\text { markers (CD19 and CD20) and } \\
\text { tetraspanins (CD37, CD53, and } \\
\text { CD82) }\end{array}$ & $\begin{array}{l}\text { The blood plasma of patients with chronic } \\
\text { lymphocytic leukemia (CLL) } \\
\text { The eight-week-old NSG mice } \\
\text { The Bone Marrow-Derived Mesenchymal } \\
\text { Stem Cells (BM-MSCs) } \\
\text { The BM-derived stromal cell line HS-5, and } \\
\text { the endothelial cell line HMEC-1 } \\
\text { The primary PKH67-labeled CLL cells }\end{array}$ & $\begin{array}{l}\text { Flow cytometry assay, qRT- } \\
\text { PCR analysis, and Western } \\
\text { blotting }\end{array}$ & $\begin{array}{l}\text { Exosome uptake by endothelial cells promoted angiogenesis ex vivo } \\
\text { and in vivo, and coinjection of CLL-derived exosomes and CLL cells } \\
\text { enhanced tumor growth in immunodeficient mice. Also, the results } \\
\text { showed a-smooth actin-positive stromal cells in lymph nodes of CLL } \\
\text { patients. }\end{array}$ & $\begin{array}{c}\text { (Paggetti et al. } \\
2015 \text { ) }\end{array}$ \\
\hline MiR-1908, and MiR-298 & $\begin{array}{l}\text { The human myeloid leukemia (CML) cell line } \\
\text { K562 }\end{array}$ & $\begin{array}{l}\text { qRT-PCR analysis, and } \\
\text { Western blotting }\end{array}$ & $\begin{array}{l}\text { The expression level of miRNAs were different among K562 cells and } \\
\text { K562 cell-derived exosomes. Thus, Selectively expressed miRNAs in } \\
\text { exosomes may promote the development of CML via effects on } \\
\text { interactions (e.g. adhesion) of CML cells with their } \\
\text { microenvironment. }\end{array}$ & (Feng et al. 2013) \\
\hline CD81, Alix, Tsg101, and TGF- $\beta 1$ & $\begin{array}{l}\text { The human chronic myeloid leukemia cell } \\
\text { line LAMA84 cells } \\
\text { The four-to-five weeks old NOD/SCID mice }\end{array}$ & $\begin{array}{l}\text { qRT-PCR analysis, Enzyme- } \\
\text { linked immunosorbent assay } \\
\text { (ELISA), and Western } \\
\text { blotting }\end{array}$ & $\begin{array}{l}\text { The exosome-treated LAMA84 cells there is the reduction of BAD and } \\
\text { BAX proteins, as well as an increase in the protein levels of BCL-xl, } \\
\text { BCL-w. Moreover, CML exosomes stimulate the proliferation and } \\
\text { survival of the producer cells via the activation of ERK, Akt and NF- } \\
\text { kB. }\end{array}$ & $\begin{array}{c}\text { (Raimondo et al. } \\
\text { 2015) }\end{array}$ \\
\hline
\end{tabular}




\begin{tabular}{|c|c|c|c|c|}
\hline $\begin{array}{l}\text { VEGF, Tax, CXCR4, Nanog, MMP-9, } \\
\text { N-Cadherin, } \alpha \text {-SMA, MiR-21, and } \\
\text { MiR-155 }\end{array}$ & $\begin{array}{l}\text { The leukemic cell lines HTLV-I negative } \\
\text { (Molt-4) or positive (C81 and HuT-102) } \\
\text { The peripheral blood plasma of acute ATL } \\
\text { patients } \\
\text { The human mesenchymal stem cell line } \\
\text { MSCs }\end{array}$ & $\begin{array}{l}\text { qRT-PCR analysis, Enzyme- } \\
\text { linked immunosorbent assay } \\
\text { (ELISA), and Western } \\
\text { blotting }\end{array}$ & $\begin{array}{l}\text { The cargo of HuT-102-derived exosomes included of miR-21, miR- } \\
155 \text { and vascular endothelial growth factor. Also, HuT-102-derived } \\
\text { exosomes not only deliver Tax to recipient MSCs, but also induce NF- } \\
\mathrm{\kappa B} \text { activation leading to an alteration in cellular morphology, } \\
\text { promote in proliferation and the induction of gene expression of } \\
\text { migration and angiogenic markers. }\end{array}$ & $\begin{array}{c}\text { (El-Saghir et al. } \\
\text { 2016) }\end{array}$ \\
\hline $\begin{array}{l}\text { TGF } 1 \text {, latency-associated protein } \\
\text { (LAP), CD9, CD81, CD34, and CD } \\
117\end{array}$ & $\begin{array}{l}\text { The blood plasma of acute myeloid } \\
\text { leukemia (AML) patients at diagnosis, post- } \\
\text { induction CT, during consolidation CT, in } \\
\text { long-term remission, and from healthy } \\
\text { volunteers }\end{array}$ & $\begin{array}{l}\text { Flow cytometry assay, } \\
\text { Enzyme-linked } \\
\text { immunosorbent assay } \\
\text { (ELISA), and Western } \\
\text { blotting }\end{array}$ & $\begin{array}{l}\text { The changes in total exosomal protein levels and the presence of } \\
\text { various forms of transforming growth factor-beta1 (TGF-b1) carried } \\
\text { by AML exosomes reflect effects of remedy and might serve as } \\
\text { indicators of leukemic relapse in AML patients. Besides, AML } \\
\text { exosomes carrying an active form of TGF-b1 induced down- } \\
\text { regulation of NKG2D expression in normal natural killer (NK) cells. }\end{array}$ & $\begin{array}{l}\text { (Hong et al. } \\
\text { 2014a) }\end{array}$ \\
\hline HSP70, and ABL & $\begin{array}{l}\text { The DBA/2 mice (Dilute Brown Non-Agouti) } \\
\text { The chronic myeloid leukemia (CML) cell } \\
\text { line K562 } \\
\text { The mouse lymphocytic leukemia cells } \\
\text { L1210 } \\
\text { The DBA/2 mouse leukemia cell line } \\
\text { The Menogaril-resistant mouse leukemia } \\
\text { P388 cells }\end{array}$ & $\begin{array}{l}\text { Flow cytometry assay, and } \\
\text { Western blotting }\end{array}$ & $\begin{array}{l}\text { The EXOK562-pulsed DCs activate CTLs in vitro, which kill target } \\
\text { cells more powerfully than CTLs induced by EXOK562 alone or by } \\
\text { DCs pulsed with cell lysates. Moreover, LEXs induce antileukemic } \\
\text { immunity and that LEX-pulsed DCs have the more potent antigen- } \\
\text { specific antileukemic effects, because all mice injected with non- } \\
\text { pulsed DCs developed tumors. }\end{array}$ & (Yao et al. 2014) \\
\hline $\begin{array}{l}\text { CD63, CD81, CD34, CD200, CD44, } \\
\text { and CD105 }\end{array}$ & $\begin{array}{l}\text { The human CD34+ leukemic cell line } \\
\text { The blood plasma samples of newly- } \\
\text { diagnosed AML patients and from healthy } \\
\text { volunteers }\end{array}$ & $\begin{array}{l}\text { Flow cytometry assay, } \\
\text { Enzyme-linked } \\
\text { immunosorbent assay } \\
\text { (ELISA), and Western } \\
\text { blotting }\end{array}$ & $\begin{array}{l}\text { The blast-derived exosomes can be quantitatively ameliorated from } \\
\text { AML patients' plasma and that their molecular profile recapitulates } \\
\text { that of the blasts. These isolated exosomes are biologically-active, } \\
\text { trigger immune inhibition and might be helpful for AML diagnosis } \\
\text { and prognosis. }\end{array}$ & $\begin{array}{l}\text { (Hong et al. } \\
2014 b \text { ) }\end{array}$ \\
\hline CD63, CD81, and Tsg101 & $\begin{array}{l}\text { The chronic myeloid leukemia (CML) cell } \\
\text { line K562 } \\
\text { The human umbilical vein endothelial cells } \\
\text { (HUVEC) } \\
\text { Four-week-old BALB/c nude mice }\end{array}$ & $\begin{array}{l}\text { Immunoblot analysis, } \\
\text { Endothelial tube formation } \\
\text { assay, XTT cell viability } \\
\text { assay, and Matrigel plug } \\
\text { assay }\end{array}$ & $\begin{array}{l}\text { Exosomes released by K562 CML cells are internalized via } \\
\text { endothelial cells during tubular differentiation on Matrigel and are } \\
\text { shuttled to neighboring cells via the formation of nanotubular } \\
\text { structures connecting the cells. Also, these exosomes stimulate tube } \\
\text { formation in endothelial cells via Src activation. While both imatinib } \\
\text { and dasatinib reduced exosome release from K562 cells, only } \\
\text { dasatinib blocked exosome effect on endothelial cells. }\end{array}$ & $\begin{array}{l}\text { (Mineo et al. } \\
\text { 2012) }\end{array}$ \\
\hline
\end{tabular}


Interleukin-8 (IL-8)

\begin{tabular}{|l}
\hline \\
Alix, CD81, Tsg101, Interleukin 3
\end{tabular}

(IL3), and Lamp2b
The human vascular endothelial cells (HUVECs)

The human chronic myeloid leukemic cell lin

The human peripheral blood mononuclear cells (PBMC)

Four week old BALB/c nude mice

The human embryonic kidney cell line HEK293T cells

The chronic myelogenous leukemia cell lines LAMA84, K562, and Imatinib resistant K562 cells

Four to five weeks old female NOD/ SCID mice

GATA1, FOXP3, SHIP1, ID1, E2F1, CEBP-a and -b, Myc, and MEF2C, specifically, nucleophosmin 1 (NPM1), FLT3, CXCR4, MMP9 IGFIR, Let-7a, MiR-9, MiR-99b, MiR150, MiR-155, MiR-191, MiR-223, MiR-146a, and MiR-150

\section{Statistical analysis indicated that} out of a total of 4,232 protein exosomes and exosomes (Wojtuszkiewicz et al. 2016)

The human p190 19 BR-ABL driven ALL cells line (ALL3)

The chronic myeloid leukemia (CML) cell line K562, R10(-), Mo7, and CML CD34+ cells

Eight to ten weeks old female NOD/ SCID mice

qRT-PCR analysis, Flow cytometry assay, Enzyme linked immunosorbent assay ELISA)

recipitation assay and Western blotting LAMA84 CML cells both ICAM-1 and VCAM-1 cell adhesion expression. Also, the treatment with exosomes from CML cells caused an increase in endothelial cell motility accompanied by a loss of VEcadherin and $\beta$-catenin from the endothelial cell surface.

Taverna et al. 2012)

qRT-PCR analysis, Atomic Force Microscopy (AFM) assay, and Western blottin

The HEK293T cells was engineered to express the exosomal protein Lamp2b, fused to a fragment of Interleukin 3 (IL3). The modified exosomes, including IL3-Lamp2B, which loaded with Imatinib, are able to particularly target tumor cells in vivo, causing the decrease in tumor size. Thus, the modified exosomes are able to deliver functional BCR-ABL siRNA towards Imatinib-resistant CML cells.

Bellavia et al. 2017)

qRT-PCR analysis, Flow cytometry assay, and Western blotting

Profiling the mRNA content of these microvesicles indicated the presence of transcripts relevant to AML prognosis (FLT3-ITD, NPM1), treatment (FLT3-ITD, IGF-IR CXCR4), and niche function (IGF-IR, CXCR4 MMP9). Also both miR-150 and CXCR4 mRNA are present in AML exosomes, miR-150 is highly enriched therein and exosome transfer to $\mathrm{Ba} / \mathrm{F} 3$ prose CXCR4 suface expression and consecuent reduce in cell migration toward SDF-1a. Immunocytochemistry assay, The expression of apoptosis-regulating proteins (B-cell like 1 - BCL-X 2 - BCL-2, Myeloid Cell Leukemia 1 -MCL-1, BCL-2 like 1 - BCL-X and BCL-2-associated X protein - BAX) in AML blasts a diagnosis is associated with disease-free survinal. The intraindividual ex vivo apoptosisblasts within the bone marow of AML patients were increasingly core expresion in sensitive AML blasts in contact cultures.

[3H]-Thymidine incorporation assay Enzyme-linked immunosorbent assay (ELISA), and Wester blotting
The HD ALL3 cells are able to secret exosomes in large quantities and that they are capable of trigger the growth of the LD ALL3 cells without which they will not survive. Direct stimulation of nongrowing LD ALL3 cells using purified exosomes shows that the ALL3 cells can also communicate with each other by means of exchange of exosomes independently of direct cell-cell contacts or diffusible soluble stimulatory factors secreted by HD ALL3 cells. 


\begin{tabular}{|c|c|c|c|c|}
\hline TGF- $\beta 1$, Hsc70, and NKG2D & $\begin{array}{l}\text { The chronic myeloid leukemia (CML) cell } \\
\text { line K562 } \\
\text { The viable imatinib-resistant cells } \\
\left(\mathrm{K}^{2} 62 \mathrm{R}^{\mathrm{IMT}} \text { ) }\right.\end{array}$ & $\begin{array}{l}\text { Flow cytometry analysis, and } \\
\text { Western blotting }\end{array}$ & $\begin{array}{l}\text { The Dasatinib promotes cellular apoptosis via suppression of } \\
\text { Akt/mTOR activities, and prevents exosomal release via } \\
\text { downregulation of beclin- } 1 \text { and Vps } 34 \text {-dependent autophagic } \\
\text { activity, containing distinct dasatinib-induced mechanisms of } \\
\text { apoptotic response and exosomes release in imatinib-resistant CML } \\
\text { cells. }\end{array}$ & (Liu et al. 2016) \\
\hline Interleukin-8 (IL 8) & $\begin{array}{l}\text { The chronic myelogenous leukemia cell line } \\
\text { LAMA84 cells } \\
\text { The bone marrow-derived stromal cell line } \\
\text { HS5 cells } \\
\text { Four-to-five week old male NOD/SCID mice }\end{array}$ & $\begin{array}{l}\text { qRT-PCR analysis, Enzyme- } \\
\text { linked immunosorbent assay } \\
\text { (ELISA), and Western } \\
\text { blotting }\end{array}$ & $\begin{array}{l}\text { Serum IL } 8 \text { levels enhanced in hematologic malignancies compared to } \\
\text { healthy controls and promoted expression of IL } 8 \text { and its receptors } \\
\text { has been indicated in cancer cells and stromal cells illustrating that IL } \\
8 \text { may modulate tumors microenvironment. Thus, LAMA84-derived } \\
\text { exosomes are able to activate bone marrow stromal cells which in } \\
\text { turn release IL } 8 \text { acting as an in vitro and in vivo pro survival factor } \\
\text { for chronic myelogenous leukemia cells. }\end{array}$ & $\begin{array}{c}\text { (Corrado et al. } \\
\text { 2014) }\end{array}$ \\
\hline $\begin{array}{l}\text { The NKG2D ligands (MICA/B, } \\
\text { ULBP1, ULBP2), and HSP70 }\end{array}$ & $\begin{array}{l}\text { The human T cell leukemia Jurkat- and B cell } \\
\text { leukemia/lymphoma Raji cell lines }\end{array}$ & $\begin{array}{l}\text { qRT-PCR analysis, Flow } \\
\text { cytometry assay, and } \\
\text { Western blotting }\end{array}$ & $\begin{array}{l}\text { The NKG2DL-carrying exosomes abrogate NKG2D-mediated NK-cell } \\
\text { cytotoxicity and, thus, might contribute to the immune evasion of } \\
\text { leukemia/lymphoma cells T- and B-cell lines Jurkat and Raji as } \\
\text { hematopoietic malignancy models. }\end{array}$ & $\begin{array}{c}\text { (Hedlund et al. } \\
\text { 2011) }\end{array}$ \\
\hline $\begin{array}{l}\text { CD40, CD86, HSP60, HSP70, HSP90, } \\
\text { RANTES, and IL-1b }\end{array}$ & $\begin{array}{l}\text { The six-to-eight week old female BALB/c (H- } \\
\text { 2d) and C57BL/6J (H-2b) mice } \\
\text { The mouse B cell lymphoma/leukemia cell } \\
\text { line A20 (H-2d) cells } \\
\text { The colon tumor } 26 \text { (CT-26) of colon } \\
\text { adenocarcinoma in BALB/c mice }\end{array}$ & $\begin{array}{l}\text { Antigen presentation assay, } \\
\text { Flow cytometry analysis, } \\
\text { Enzyme-linked } \\
\text { immunosorbent assay } \\
\text { (ELISA), and Western } \\
\text { blotting }\end{array}$ & $\begin{array}{l}\text { The exosomes derived from heat-shocked lymphoma cells contain } \\
\text { more HSP60 and HSP90 and increased amounts of molecules } \\
\text { involved in immunogenicity including MHC class I, MHC class II, } \\
\text { CD40, CD86, RANTES and IL-1b. Consistent with the in vitro results } \\
\text { the HS-Exo exhibit a more potent antitumor effect than control } \\
\text { exosomes in prophylaxis and therapeutic in vivo lymphoma models. }\end{array}$ & (Chen et al. 2006) \\
\hline $\begin{array}{l}\text { HLA class I and II molecules such as } \\
\text { HLA-B, HLA-C histocompatibility } \\
\text { antigen, B-15 alpha chain, B-39 } \\
\text { alpha chain, A-26 alpha Chain, HLA- } \\
\text { DQA1 MHC } \\
\text { class II antigen, HLA class II } \\
\text { histocompatibility antigen, } \\
\text { DQ(1) beta Chain, HLA-C antigen, } \\
\text { Cw-4 alpha and Cw-3 } \\
\text { alpha chain, HLA-DPB1 major } \\
\text { histocompatibility complex, } \\
\text { class II, DP beta1, CD19, CD20, } \\
\text { CD22, CD81, CD82, antigen and } \\
\text { intercellular adhesion molecule 1, } \\
\text { etc }\end{array}$ & $\begin{array}{l}\text { The human B cell leukemia/lymphoma Raji } \\
\text { cell lines }\end{array}$ & $\begin{array}{l}\text { Mass spectrometry assay, } \\
\text { and Western blotting }\end{array}$ & $\begin{array}{l}\text { The lymphoma cell-derived exosomes (LCEXs) expressed a discrete } \\
\text { set of proteins involved in antigen presentation and cell migration } \\
\text { and adhesion, indicating that LCEXs play a significant role in the } \\
\text { regulation of immunity and interaction between lymphoma cells and } \\
\text { their microenvironment. }\end{array}$ & (Yao et al. 2015) \\
\hline
\end{tabular}




\begin{tabular}{|c|c|c|c|c|}
\hline $\begin{array}{l}\text { ALIX, TSG-101, CD63, CD9, CD81, } \\
\text { CD24, HSP70, and HSP90 }\end{array}$ & $\begin{array}{l}\text { The syngeneic BALB/c T-cell lymphoma cell } \\
\text { line LBC (H-2d) cells } \\
\text { Six- to ten-week-old female } \\
\text { immunocompetent BALB/c mice }\end{array}$ & $\begin{array}{l}\text { Flow cytometry analysis, } \\
\text { Enzyme-linked } \\
\text { immunosorbent assay } \\
\text { (ELISA), Dot blot and } \\
\text { Western blotting }\end{array}$ & $\begin{array}{l}\text { T-cells from EVs A-immunized mice secreted IFN- } \gamma \text { in response to } \\
\text { tumor stimulation. Thus, tumor-specific CD4+ and CD8+ IFN- } \gamma \\
\text { secreting cells could be effectively expanded from mice immunized } \\
\text { with EVs A, indicating that a T helper } 1 \text { response is associated with } \\
\text { tumor rejection. }\end{array}$ & $\begin{array}{l}\text { (Menay et al. } \\
\text { 2017) }\end{array}$ \\
\hline $\begin{array}{l}\text { CD63, CD81, CD19, CD20, CD22, } \\
\text { CD23, CD24, CD37, CD40, and CD45 }\end{array}$ & $\begin{array}{l}\text { The B-cell lymphoma cell lines Ramos, } \\
\text { SUDHL-4, SUDHL-6, and Ros- } 50 \text { cells } \\
\text { The colon adenocarcinoma SW } 480 \text { cell line }\end{array}$ & $\begin{array}{l}\text { qRT-PCR analysis, Flow } \\
\text { cytometry assay, Electron } \\
\text { microscopy assay, and } \\
\text { Western blotting }\end{array}$ & $\begin{array}{l}\text { The several B-cell surface antigens including CD19, CD20, CD24, } \\
\text { CD37, and HLA-DR, but not CD22, CD23, CD40, and CD45 are } \\
\text { expressed on exosomes from B-cell lymphoma cell lines with large } \\
\text { heterogeneity among the different B-cell lymphoma cell lines. } \\
\text { Interestingly, these B-cell lymphoma-derived EVs are able to rescue } \\
\text { lymphoma cells from rituximab-induced complement-dependent } \\
\text { cytotoxicity. }\end{array}$ & $\begin{array}{l}\text { (Oksvold et al. } \\
\text { 2014) }\end{array}$ \\
\hline $\begin{array}{l}\text { CD63, CD81, CD20, CD19, MCL4, } \\
\text { MCL8, and MCL7 }\end{array}$ & $\begin{array}{l}\text { The Mantle cell lymphoma cell lines Jeko-1, } \\
\text { and Mino cells } \\
\text { The Jurkat human acute T cell leukemia cell } \\
\text { line and HS-5 human bone marrow derived } \\
\text { stroma cell line } \\
\text { The blood plasma of MCL patients and } \\
\text { healthy donors }\end{array}$ & $\begin{array}{l}\text { qRT-PCR analysis, Flow } \\
\text { cytometry assay, Electron } \\
\text { microscopy assay, } \\
\text { Nanoparticle tracking } \\
\text { analysis (NTA), and Western } \\
\text { blotting }\end{array}$ & $\begin{array}{l}\text { The MCL exosomes are quickly and preferentially internalized via B- } \\
\text { lymphocytes. Only minor fraction of exosomes was internalized into } \\
\text { T-cell leukemia and bone marrow stroma cell lines, when these cells } \\
\text { were co-cultured with MCL cells. Thus, exosome internalization was } \\
\text { not suppressed by specific siRNA against caveolin1 and clathrin but } \\
\text { was found to be mediated by cholesterol-dependent pathway. }\end{array}$ & $\begin{array}{l}\text { (Hazan-Halevy et } \\
\text { al. 2015) }\end{array}$ \\
\hline MiR-9, MiR-146a, and MiR-155 & $\begin{array}{l}\text { The human Burkitt's lymphoma cell lines } \\
\text { Raji, and Ramos cells } \\
\text { The retinal pigment epithelial cell line ARPE- } \\
19 \text { cells } \\
\text { The human umbilical vein endothelial cells } \\
\text { (HUVECs) }\end{array}$ & $\begin{array}{l}\text { qRT-PCR analysis, Enzyme- } \\
\text { linked immunosorbent assay } \\
\text { (ELISA), and Western } \\
\text { blotting }\end{array}$ & $\begin{array}{l}\text { Raji-exosome mediated delivery of miR-155 inhibitor diminished } \\
\text { endogenous and secreted levels of VEGF-A in ARPE- } 19 \text { cells. Also, a } \\
\text { significant increase in cellular levels of miR-9, miR-146a, and miR- } \\
155 \text { in co-cultures of Raji cell compared with EBV-negative B cells } \\
\text { was detected. }\end{array}$ & (Yoon et al. 2016) \\
\hline Wnt3a, and SFRP4 & $\begin{array}{l}\text { The diffuse large B-cell lymphoma (DLBCL) } \\
\text { cell lines SUDHL4, U2932, OCI Ly1, OCI Ly3, } \\
\text { and Karpas } 422 \text { cells } \\
\text { The human B-lymphocytic lymphoma cell } \\
\text { lines BALM-3 cells } \\
\text { The spontaneously immortalized cell line L- } \\
\text { Wnt3a cells }\end{array}$ & $\begin{array}{l}\text { qRT-PCR analysis, Flow } \\
\text { cytometry assay, and } \\
\text { Western blotting }\end{array}$ & $\begin{array}{l}\text { The diffuse large B-cell lymphomas possessed a self-organized } \\
\text { infrastructure comprising side population (SP) and non-SP cells, } \\
\text { where transitions between clonogenic states are modulated by } \\
\text { exosome mediated Wnt signaling. Lymphoma SP cells displayed } \\
\text { autonomous clonogenicity and exported Wnt } 3 \text { a via exosomes to } \\
\text { neighboring cells, thus modulating population equilibrium in the } \\
\text { tumor. }\end{array}$ & (Koch et al. 2014) \\
\hline $\begin{array}{l}\text { MiR-96-5p, MiR-182-5p, and MiR- } \\
149\end{array}$ & $\begin{array}{l}\text { The human colon carcinoma cell lines HT- } 29 \\
\text { and HCT- } 116 \text { cells } \\
\text { The peripheral fasting blood specimens of } \\
\text { colon carcinoma patients } \\
\text { The human colon carcinoma tissues and } \\
\text { normal tissue samples }\end{array}$ & $\begin{array}{l}\text { qRT-PCR analysis, Flow } \\
\text { cytometry assay, and } \\
\text { Western blotting }\end{array}$ & $\begin{array}{l}\text { The considerably promoted GPC1+ exosomes are present in the } \\
\text { plasma of CRC patients and can be released from CRC tumor cells. } \\
\text { The high expression of miR-96-5p and miR- } 149 \text { significantly } \\
\text { decreased cell viability and enhanced cell apoptosis in HT- } 29 \text { and } \\
\text { HCT- } 116 \text { cells, and suppressed the growth of xenograft HT- } 29 \text { and } \\
\text { HCT- } 116 \text { tumors. }\end{array}$ & (Li et al. 2017) \\
\hline
\end{tabular}


Dickkopf-related protein 4 (DKK4)

Tumor suppressor-activated
pathway 6 (TSAP6)
CD9, CD97, ERK, JNK, p38, HSP70,
MiR-2861, MiR-4734, MiR-4728-5p,
MiR-6165

MiR-6165

\section{fibronectin 1 (FN1), and \\ laminin, gamma 1 (LAMC1)}

Epidermal growth factor receptor (EGFR)

HLA-A, and CD9
The human colon carcinoma cell lines SW480 and SW480APC

The human colon carcinoma cell line HCT116 TP53-wild type, and HCT-116

TP53-null cells

The human colon carcinoma tissues and normal tissue samples

The peripheral fasting blood specimens of colon carcinoma patients

The stomach adenocarcinoma cell line SGC7901 cells

The human gastric cancer cell lines KatoIII MKN45, and MKN74 cells

The human normal mesothelial

cell line MeT-5A cells

The human GC liver metastatic and paired adjacent non-cancerous tissues

Male nude mice (BALB/c-nu, 6 to 8 weeks)

The human gastric adenocarcinoma cell line SGC7901 cells

The primary mouse liver cells were obtained from the livers of C57BL/6J mice (6-8 weeks of age)

The human gastric adenocarcinoma cell line SGC7901 and Jurkat T cells
qRT-PCR analysis, Electron

Western blotting

qRT-PCR analysis, Flow cytometry assay, and Western blotting

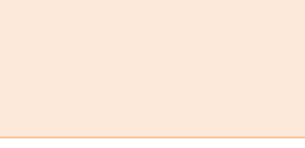

qRT-PCR analysis, Electron microscopy assay, and

Western blotting

\section{qRT-PCR analysis, and}

Western blotting

qRT-PCR analysis, Enzymelinked immunosorbent assay assay, Nanoparticle tracking assay, Nanoparticle tracking

The secretion of Wnt antagonist, dickkopf-related protein 4 (DKK4) enhanced in SW480APC colon carcinoma cells derived exosomes. In addition, the promoter region of the DKK4 gene appears to have decreased methylation in SW480APC cells, comparing with the paternal SW480 cels, as well as reduced expression of DNA methyltransferase 3a (DNMT-3a).

The expression of TSAP6 is not related with release of exosomes; and regulation of TSAP6 through P53 was not detected either in tumor samples or in HCT-116cell lines. Besides, it was not shown that the P53/TSAP6 pathway regulates the release of exosomes into the plasma of colorectal cancer patients.

(Silva et al. 2012)

CD97 elevates gastric cancer cell proliferation and invasion in vitro via exosome-mediated MAPK signaling pathway, and also exosomal miRNAs including miR-2861 and miR-4734 are probably involved in activation of the CD97-associated pathway. The expression of adhesion-related molecules, including fibronectin 1 (FN1) and laminin gamma 1 (LAMC1), were promoted in mesothelial gastric cancer cell line and malignant pleural effusion.

The EGFR-containing exosomes derived from cancer cells is demonstrated to impressively activate hepatocyte growth factor (HGF) by inhibiting miR-26a/b expression. In addition, the high expressed of paracrine HGF, which binds the c-MET receptor on the migrated cancer cells, provides fertile 'soil' for the 'seed', simplifying the landing and proliferation of metastatic cancer cells.

Zhang et al. 2017)

qRT-PCR analysis, Electro microscopy assay, Western blotting and Immunoprecipitation
The Cbl family of ubiquitin ligases might be involved in regulation of exosome-induced apoptosis of Jurkat $\mathrm{T}$ cells by promoting PI3K proteasome degradation, inactivation of PI3K/Akt signaling, and mediating some effects of caspase activation. 


\begin{tabular}{|c|c|c|c|c|}
\hline $\begin{array}{l}\text { MiR-203, MiR-212-3p } \\
\text { Several proteins (attractin, } \\
\text { complement proteins C3, C4 and C5, } \\
\text { integrin, and lactotransferrin) }\end{array}$ & $\begin{array}{l}\text { The human pancreatic carcinoma epithelial } \\
\text { like cell line PANC-1 cells }\end{array}$ & $\begin{array}{l}\text { Liquid chromatography- } \\
\text { electro spray ionization mass } \\
\text { spectrometry/mass } \\
\text { spectrometry (LC- } \\
\text { ESIMS/MS) analysis, } \\
\text { Enzyme-linked } \\
\text { immunosorbent assay } \\
\text { (ELISA), and Western } \\
\text { blotting }\end{array}$ & $\begin{array}{l}\text { The pancreatic cancer (PC)-derived exosomes down regulated the } \\
\text { expression of TRL4 in dendritic cells (DCs) through miR-203, } \\
\text { including immune tolerance. Therefore, the PC-derived exosomal } \\
\text { miRNAs can down regulate the anti-tumor activity of DC/cytokine- } \\
\text { induced killer cells (CIKs) and that depletion of exosomal miRNAs can } \\
\text { promote the anti-tumor activity of DC/CIKs. }\end{array}$ & (Que et al. 2016) \\
\hline CD63, TSG101, and Alix & $\begin{array}{l}\text { The pancreatic cancer patient-derived cell } \\
\text { lines 6741-1 (MCPAN014), 6413-1 } \\
\text { (MCPAN013), 5822-1 (MCPAN008), 7135-1, } \\
\text { 7426-1, and 7291-1 cells } \\
\text { Murine 3T3-L1 preadipocytes } \\
\text { The blood collection and tissue samples of } \\
\text { pancreatic cancer patients }\end{array}$ & $\begin{array}{l}\text { Enzyme-linked } \\
\text { immunosorbent assay } \\
\text { (ELISA), } \\
\text { Immunoprecipitation, and } \\
\text { Western blotting }\end{array}$ & $\begin{array}{l}\text { Lipolysis in 3T3-L1 cells and in human adipocytes enhanced upon } \\
\text { exposure to PC-exosomes. Increase in lipolysis is attributed to } \\
\text { adrenomedullin (AM) contained within PC-exosomes, as AM receptor } \\
\text { blockade led to abrogation of the effect of exosomes and activation of } \\
\text { ERK1/2 and p38 MAPKs in both murine and human adipocytes. }\end{array}$ & (Sagar et al. 2015) \\
\hline HSP70 & $\begin{array}{l}\text { The MIA Paca-2, an epithelial-like pancreatic } \\
\text { cancer cell line }\end{array}$ & $\begin{array}{l}\text { Electron microscopy assay, } \\
\text { Western blotting }\end{array}$ & $\begin{array}{l}\text { The EXO/SEB is a novel model or apopto-immunotherapy, being able } \\
\text { to induce apoptosis in addition to specific immune responses. The } \\
\text { enhanced expression of antiapoptotic genes including bax, bak and } \\
\text { fas in cells treated with the EXO/SEB causes promotion of apoptosis. } \\
\text { In addition, EXOs released from pancreatic cancer cells can trigger } \\
\text { the mitochondrial-dependent apoptosis and increase the caspase-3 } \\
\text { and caspase-9 activities. }\end{array}$ & $\begin{array}{l}\text { (Mahmoodzadeh } \\
\text { et al. 2014) }\end{array}$ \\
\hline $\begin{array}{l}\text { Alix, TSG101, CHMP4B, and ATP- } \\
\text { binding cassette sub-family G } \\
\text { member } 2 \text { (ABCG2) }\end{array}$ & $\begin{array}{l}\text { The human pancreatic cancer cell lines } \\
\text { AsPC- } 1 \text { and PANC- } 1\end{array}$ & $\begin{array}{l}\text { qRT-PCR analysis, Electron } \\
\text { microscopy assay, Western } \\
\text { blotting, and Proteomics } \\
\text { analysis }\end{array}$ & $\begin{array}{l}\text { The involvement of GIPC on metabolic stress pathways regulating } \\
\text { autophagy and microvesicular shedding, and observed that GIPC } \\
\text { status determines the loading of cellular cargo in the exosome. Thus, } \\
\text { the detection showed the overexpression of the drug resistance gene } \\
\text { ABCG2 in exosomes from GIPC-depleted pancreatic cancer cells. }\end{array}$ & $\begin{array}{l}\text { (Bhattacharya et } \\
\text { al. 2014) }\end{array}$ \\
\hline KRAS & $\begin{array}{l}\text { Blood plasma samples of } 39 \text { early-stage } \\
\text { pancreatic ductal adenocarcinoma (PDAC) } \\
\text { patients and } 82 \text { agematched healthy controls }\end{array}$ & $\begin{array}{l}\text { qRT-PCR analysis, Flow } \\
\text { cytometry assay, Electron } \\
\text { microscopy assay, and } \\
\text { Western blotting }\end{array}$ & $\begin{array}{l}\text { By comparing exoDNA to cfDNA in liquid biopsies of patients with } \\
\text { pancreatic ductal adenocarcinoma, the higher exoKRAS mutant allele } \\
\text { frequency, but not CA19-9, was associated with disease free survival } \\
\text { in patients with localized disease. }\end{array}$ & $\begin{array}{l}\text { (Allenson et al. } \\
\text { 2017) }\end{array}$ \\
\hline $\begin{array}{l}\text { CD44v6, Tspan8, EpCAM, MET, } \\
\text { CD104, CD184, Tspan8, CD24, } \\
\text { CD133, CD9, CD63, CD151, MiR- } \\
\text { 1246, MiR-4644, MiR-3976, and } \\
\text { MiR-4306 }\end{array}$ & $\begin{array}{l}\text { Blood collection samples from } 131 \text { PaCa, } 25 \\
\text { chronic pancreatitis (CP), } 22 \text { benign } \\
\text { pancreatic tumor and } 12 \text { patients with non- } \\
\text { PaCa, and } 30 \text { volunteers } \\
\text { The human PaCa tumor cell lines AsPC1, } \\
\text { Capan1, Panc1, ExPC3, A818 cells }\end{array}$ & $\begin{array}{l}\text { qRT-PCR analysis, Flow } \\
\text { cytometry assay, and } \\
\text { Microarray miRNA analysis }\end{array}$ & $\begin{array}{l}\text { MiR-1246, miR-4644, miR-3976, and miR-4306 were significantly } \\
\text { upregulated in } 83 \% \text { of PaCa serum-exosomes, but rarely in control } \\
\text { groups. These miRNA were also elevated in exosome-depleted serum } \\
\text { of patients with PaCa, but at a low level. Also, the expression of the } \\
\text { PaCIC markers CD24, CD44v6, CD104, Tspan8, EpCAM, MET, and } \\
\text { CD151 and the common exosome markers CD9 and CD63 was based } \\
\text { on high expression in tumor tissue. }\end{array}$ & $\begin{array}{l}\text { (Madhavan et al. } \\
\text { 2015) }\end{array}$ \\
\hline
\end{tabular}


Alix, CD9, CD63, CD81, syntenin calreticulin, calpain 1 , VDAC 1 vimentin, growth factor, casein kinase II $\alpha$ and annexin A2

\section{InARS (InRNA ACIVTated in}

IncARSR (lncRNA Activated in RCC with Sunitinib Resistance), HSC70, ALIX, CD43, heterogeneous nuclea ribonucleoprotein VPS36, and CD63

S36, and CD63

MiR-34a, MiR-141, MiR-134, MiR135a, MiR-135b, and MiR-370

MiR-378a, MiR-379, MiR-139- 5p, MiR-200b-5p, MiR-151a-5p, MiR30a-3p, MiR-200b-5p, MiR-629, MiR-100, and MiR-154-3p

MiR-17-3p, MiR-21, MiR-106a, MiR146, MiR-155, MiR-191, MiR-192, MiR-203, MiR-205, MiR-210, MiR212 , and MiR-214

Curcumin (anti-cancer drug for lung cancer remedy)
The human urinary bladder transitional cell carcinoma cell lines T24, FL3,

and SLT4 cells

The nude mice grafted with 786-0 and ACHN cells

The renal cell carcinoma (RCC) cell lines 786-0, and ACHN

The sunitinib-resistant RCC cells 7Su3rd, 771S, 771R, ACSu3rd

The adenocarcinomic human alveolar basal epithelial cell line A549 cells

The collection of non-small cell lung cancer (NSCLC) patient tissue samples

30 blood plasma samples (10 patients affected by lung adenocarcinomas, 10 with lung granulomas, and 10 healthy smokers)

Plasma samples from patients with lung adenocarcinoma and a control group without known lung cancer or other active cancer

The human lung cancer cell lines BEAS-2B, A549, PC9, and H1299 cells

The human lung adenocarcinoma cell lines A549, and H460 cells

$\mathrm{BALB} / \mathrm{c}$ nude male mice
LC-MS/MS analysis, Electron microscopy assay, and

Western blotting

\section{qRT-PCR analysis, Electron} microscopy assay, an Western blotting

(n)

qRT-PCR analysis, Electron microscopy assay, and Western blottin

is

YKT6 downregulation is associated with a remarkable reduction in exosome release in an NSCLC cell line and that low YKT6 expression is associated with better clinical outcome in NSCLC patients. Thus, YKT6 is a SNARE protein in the regulation of exosome release in lung cancer cells and is in turn accurately regulated by miR-134 and miR$135 \mathrm{~b}$.

The several proteins lead to EMT was detected in bladder carcinoma derived growth factor in the mence annexin A2 in the lumen of exosomes, respectively, from metastatic cells. The change in exosome protein abundance correlated litte although significant for FL3 versus T24, with alters in cellular mRNA expression.

In sunitinib-resistant renal cell carcinoma (RCC) cells, IncRNA activated in RCC with sunitinib resistance (IncARSR) elevates sunitinib resistance by competitively binding miR-34 and miR-449, STAT3, AKT, and ERK signaling. Moreover, IncARSR can be packaged into exosomes and secreted from sunitinib-resistant RCC cells, into exosones and sected from sunitinib-ris

\section{(Ruiz-Martinez et al. 2016)}

qRT-PCR analysis

The production of exosomes containing miRNAs in the lung carcinoma cells are completely different to those present in healthy control cells from which neoplastic cells originated.

\section{(Cazzoli et al.} 2013)

Microarray analysis

The considerable difference in total exosome and miRNA levels and HSP70 increased after $\beta$-elemene remedy. between lung cancer patients and controls, and the similarity between the circulating exosomal miRNA and the tumor-derived miRNA patterns, suggest that circulating exosomal miRNA might be useful as a screening test for lung adenocarcinoma.

qRT-PCR analysis, and

The anti-cancer effects of Curcumin are associated with upregulation of transcription factor 21 (TCF21), mediated by downregulation of DNMT1. Also, TCF21 overexpression and knockdown was introduced to $\mathrm{H} 1299$ cells through lentiviral system, which led to suppression and promotion of lung tumor growth, respectively.

(Wu et al. 2016)

qRT-PCR analysis, Flow cytometry assay, Electron microscopy assay, and

The $\beta$-elemene significantly suppressed growth and induced apoptosis in lung cancer cells. The levels of the anti-apoptotic genes Bcl-2 and Bcl-xl in A549 cells decreased, while expression of P53 and production of exosomes, and the exosome markers CD63, flotillin-1,

\section{(Rabinowits et al.} 2009)

Western blotting

(Li et al. 2014) 


\begin{tabular}{|c|c|c|c|c|}
\hline $\begin{array}{l}\text { CD63, Calnexin, MiR-122, MiR-126, } \\
\text { MiR-128, MiR-143, MiR-144, MiR- } \\
\text { 302a, MiR-302c }\end{array}$ & $\begin{array}{l}\text { The consecutive series of blood and } \\
\text { bronchoalveolar lavage (BAL) samples from } \\
30 \text { non-small cell lung cancer (NSCLC) } \\
\text { patients and } 75 \text { patients with non-tumor } \\
\text { pathology }\end{array}$ & $\begin{array}{l}\text { qRT-PCR analysis, MicroRNA } \\
\text { Quantitative PCR Array, and } \\
\text { Western blotting }\end{array}$ & $\begin{array}{l}\text { Exosome levels were considerably higher in plasma than in } \\
\text { bronchoalveolar lavage (BAL) samples in both groups of patients. } \\
\text { Also, in tumor patients the number of miRNAs with high expression } \\
\text { was greater in the exosomes released to plasma than in those } \\
\text { released to the airway. }\end{array}$ & $\begin{array}{c}\text { (Rodríguez et al. } \\
\text { 2014) }\end{array}$ \\
\hline $\begin{array}{l}\text { Epidermal Growth Factor Receptor } \\
\text { (EGFR) }\end{array}$ & $\begin{array}{l}\text { The human lung carcinoma cell lines HARA, } \\
\text { HARA-B, A549, RERF-LC-MS and LU65 cells } \\
\text { Primary human pulmonary alveolar } \\
\text { epithelial cell line HPAEpiC cells } \\
\text { Blood plasma samples from tumor-bearing } \\
\text { mice, and the human blood plasma } \\
\text { specimens from both healthy individuals and } \\
\text { cancer patients } \\
\text { Six-week-old male BALB/c Slc-nu/nu mice }\end{array}$ & $\begin{array}{l}\text { Enzyme-linked } \\
\text { immunosorbent assay } \\
\text { (ELISA), Electron microscopy } \\
\text { assay, and Western blotting }\end{array}$ & $\begin{array}{l}\text { The secretion of exosomes in plasma that express high levels of EGFR } \\
\text { are clearly derived from tumor tissue samples. Also, the exosomal } \\
\text { EGFR detection could potentially be applied in blood tests to } \\
\text { diagnose lung cancer because the exosomal EGFR level was higher in } \\
\text { lung cancer patients than in normal Individuals. }\end{array}$ & $\begin{array}{c}\text { (Yamashita et al. } \\
\text { 2013) }\end{array}$ \\
\hline CD9, and CD63 & $\begin{array}{l}\text { The human lung carcinoma cell lines H1299 } \\
\text { and H522 cells } \\
\text { The human pulmonary alveolar epithelial } \\
\text { cells }\end{array}$ & $\begin{array}{l}\text { Principal component analysis } \\
\text { (PCA), Enzyme-linked } \\
\text { immunosorbent assay } \\
\text { (ELISA), Electron microscopy } \\
\text { assay, and Western blotting }\end{array}$ & $\begin{array}{l}\text { The experiment showed the successful segregation of NSCLC-derived } \\
\text { exosomes from normal alveolar cell-derived exosomes using the } \\
\text { noninvasive method of SERS accompanied with PCA. Therefore, the } \\
\text { Raman signals of lung cancer cell derived exosomes and normal } \\
\text { alveolar cell-derived exosomes are well distinguished through PCA. }\end{array}$ & (Park et al. 2017) \\
\hline $\begin{array}{l}\text { Polyadenylate-binding protein } 1 \\
\text { (PABP1) }\end{array}$ & $\begin{array}{l}\text { The human duodenal cancer cell line HuTu } \\
80 \text { cells } \\
\text { The human gastric cancer cell line AZ-521 } \\
\text { cells, and the metastatic gastric cancer cell } \\
\text { line AZ-P7a cells }\end{array}$ & $\begin{array}{l}\text { qRT-PCR analysis, and } \\
\text { Western blotting }\end{array}$ & $\begin{array}{l}\text { The PABP1 is predominantly abundant in exosomes from a } \\
\text { metastatic duodenal cancer cell line even though its intracellular } \\
\text { expression levels do not vary among cell lines. Thus, AZ-P7a cells do } \\
\text { not tolerate intracellular PABP1 accumulation and are thus } \\
\text { supported into the extracellular milieu through the exosome - } \\
\text { mediated pathway. }\end{array}$ & $\begin{array}{c}\text { (Ohshima et al. } \\
\text { 2014) }\end{array}$ \\
\hline MiR-21 & $\begin{array}{l}\text { The blood plasma samples of esophageal } \\
\text { squamous cell carcinoma (ESCC) and healthy } \\
\text { volunteers } \\
\text { The human esophageal cancer cell line } \\
\text { EC9706 cells }\end{array}$ & $\begin{array}{l}\text { qRT-PCR analysis, Flow } \\
\text { cytometry assay, Microarray } \\
\text { analysis, and Western } \\
\text { blotting }\end{array}$ & $\begin{array}{l}\text { The Cy3-labeled miR-21 mimics could be transferred between } \\
\text { esophageal cancer cells by exosomes. Thus, the miR-21 mimics could } \\
\text { affect migration and invasion of recipient cells partly via modulation } \\
\text { of its target gene PDCD4 and its downstream-signaling molecules, } \\
\text { MMP- } 2 \text { and MMP-9 by using the cell co-culture system. Also, miR-21 } \\
\text { was upregulated significantly in plasma from esophageal cancer } \\
\text { patients and indicated a significant risk association for esophageal } \\
\text { cancer. }\end{array}$ & (Liao et al. 2016) \\
\hline HSP27 & $\begin{array}{l}\text { The human ovarian cancer (OC) cell lines } \\
\text { OVCAR-3 and SK-OV-3 cells }\end{array}$ & $\begin{array}{l}\text { Enzyme-linked } \\
\text { immunosorbent assay } \\
\text { (ELISA), and Western } \\
\text { blotting }\end{array}$ & $\begin{array}{l}\text { The heat shock protein HSP } 27 \text { has been correlated in OVCAR- } 3 \text { and } \\
\text { SK-OV-3 cells ovarian cancer cell lines by exosomes with } \\
\text { aggressiveness and chemoresistance and, thus, represents a } \\
\text { promising potential biomarker for OC diagnosis, prognosis, and } \\
\text { treatment response. }\end{array}$ & (Stope et al. 2017) \\
\hline
\end{tabular}




\begin{tabular}{|c|c|c|c|c|}
\hline CA-125, EpCAM, and CD24 & $\begin{array}{l}\text { The blood plasma samples of ovarian cancer } \\
\text { (OC) patients }\end{array}$ & $\begin{array}{l}\text { Flow cytometry assay, } \\
\text { Enzyme-linked } \\
\text { immunosorbent assay } \\
\text { (ELISA), Electron microscopy } \\
\text { assay, and Western blotting }\end{array}$ & $\begin{array}{l}\text { Through the exosome analysis enabled by the ExoSearch chip has } \\
\text { been applied for ovarian cancer diagnosis via quantifying a panel of } \\
\text { tumor markers from exosomes in a small-volume of blood plasma ( } 20 \\
\mu \mathrm{L}) \text {, which indicated significant diagnostic accuracy and was } \\
\text { comparable with standard Bradford assay. }\end{array}$ & (Zhao et al. 2016) \\
\hline $\begin{array}{l}\text { MiR-584, MiR-517c, MiR-378, MiR- } \\
\text { 520f, MiR-142-5p, MiR-451, MiR- } \\
\text { 518d, MiR-215, MiR-376a, MiR- } \\
\text { 133b, and MiR-367 }\end{array}$ & $\begin{array}{l}\text { The human Hepatocellular carcinoma (HCC) } \\
\text { cell lines Hep3B, HepG2, and PLC/PRF/5 } \\
\text { cells }\end{array}$ & $\begin{array}{l}\text { qRT-PCR analysis, , Flow } \\
\text { cytometry assay, and } \\
\text { Electron microscopy assay }\end{array}$ & $\begin{array}{l}\text { The HCC cell-derived exosomes can modulate } \beta \text { activated kinase-1 } \\
\text { (TAK1) expression and associated signaling and promote } \\
\text { transformed cell growth in recipient cells. Loss of TAK1 has been } \\
\text { implicated in hepatocarcinogenesis and is a biologically plausible } \\
\text { target for intercellular modulation. }\end{array}$ & $\begin{array}{l}\text { (Kogure et al. } \\
\text { 2011) }\end{array}$ \\
\hline HSP60, HSP70, and HSP90 & $\begin{array}{l}\text { The human hepatocellular } \\
\text { carcinoma cell line HepG2 and PLC/PRF/5 } \\
\text { cells } \\
\text { The erythromyeloblastoid leukemia cell line } \\
\text { K562 cells } \\
\text { The blood plasma samples of hepatocellular } \\
\text { carcinoma cells (HCC) patients and healthy } \\
\text { donors }\end{array}$ & $\begin{array}{l}\text { Enzyme-linked } \\
\text { immunosorbent assay } \\
\text { (ELISA), Flow cytometry } \\
\text { assay, Electron microscopy } \\
\text { assay, and Western blotting }\end{array}$ & $\begin{array}{l}\text { The anti-cancer drugs (Paclitaxel, Etoposide, Carboplatin, Irinotecan } \\
\text { hydrochloride, Mitoxantrone hydrochloride, Epirubicin } \\
\text { hydrochloride, Cisplatin, Mitomycin, Fluorouracil, Oxaliplatin, and } \\
\text { Gemcitabine hydrochloride) can efficiently up-regulate the } \\
\text { expression of HSPs (HSP60, HSP70, and HSP90) on the human } \\
\text { hepatocellular carcinoma cell-derived exosomes and the ability of } \\
\text { exosomal HSPs as a tumor vaccine to significantly induce NK cells } \\
\text { reacts that lead to eliciting an anti-tumor immune response in vivo. }\end{array}$ & (Lv et al. 2012) \\
\hline CD10, CD26, CD81, PrPc, and Slc3A1 & $\begin{array}{l}\text { The urine samples obtained from } \\
\text { experimental models of mouse, and male } \\
\text { Wistar rats, } 14 \text { week of age }\end{array}$ & $\begin{array}{l}\text { NanoLC-MS/MS analysis, } \\
\text { Electron microscopy assay, } \\
\text { and Western blotting }\end{array}$ & $\begin{array}{l}\text { The enhancement in the level of CD10 protein was detected in } \\
\text { urinary exosomes obtained from glycine N-methyltransferase } \\
\text { knockout mice, an animal model of chronic liver injury associated } \\
\text { with steatosis, fibrosis, and human Hepatocellular carcinoma (HCC). } \\
\text { In addition, the proteome of different vesicle populations indicates } \\
\text { several biomarkers including PrPc, Cd26, Slc3a1, Cd81, and Cd10 that } \\
\text { are detected in urinary vesicles and may be useful for diagnostic } \\
\text { purposes. }\end{array}$ & $\begin{array}{l}\text { (Conde-Vancells } \\
\text { et al. 2010) }\end{array}$ \\
\hline $\begin{array}{l}\text { MiR-16-1, MiR-21, MiR-24, MiR-31, } \\
\text { MiR-122, MiR-125b, MiR-223, MiR- } \\
\text { 410, CD29, and CD44 }\end{array}$ & $\begin{array}{l}\text { The human adult liver stem cells (HLSC) } \\
\text { were isolated from human cryopreserved } \\
\text { normal hepatocytes } \\
\text { The normal human hepatocytes and human } \\
\text { fibroblasts } \\
\text { The hepatoma cell line HepG2 cells }\end{array}$ & $\begin{array}{l}\text { qRT-PCR analysis, and } \\
\text { Western blotting }\end{array}$ & $\begin{array}{l}\text { The microvesicles (MVs) derived from HLSC suppressed the growth } \\
\text { of hepatoma tumors and cell line HepG2 cells by transferring the } \\
\text { genetic information and delivering anti-tumor miRNAs that } \\
\text { interfered with the deregulated survival and proliferation of these } \\
\text { cells. }\end{array}$ & $\begin{array}{l}\text { (Fonsato et al. } \\
\text { 2012) }\end{array}$ \\
\hline $\begin{array}{l}\text { EIF2C2 (AGO2), CHEK2, CDK2, and } \\
\text { MATK }\end{array}$ & $\begin{array}{l}\text { The human adult liver stem cells (HLSC) } \\
\text { were isolated from human cryopreserved } \\
\text { normal hepatocytes } \\
\text { Rat liver tissue samples }\end{array}$ & $\begin{array}{l}\text { qRT-PCR analysis, Enzyme- } \\
\text { linked immunosorbent assay } \\
\text { (ELISA), and Western } \\
\text { blotting }\end{array}$ & $\begin{array}{l}\text { The microvesicles (MVs) derived from HLSC may activate a } \\
\text { proliferative program in remnant hepatocytes after hepatectomy } \\
\text { through a horizontal transfer of specific mRNA subsets. The MVs- } \\
\text { mediated transfer of mRNA from HLSC to hepatocytes can display a } \\
\text { procedure that contribute to liver regulation and that could be } \\
\text { extracted in regenerative medicine. }\end{array}$ & $\begin{array}{l}\text { (Herrera et al. } \\
\text { 2010) }\end{array}$ \\
\hline
\end{tabular}




\begin{tabular}{|c|c|c|c|c|}
\hline MiR-92a, and MiR-638 & $\begin{array}{l}\text { The hepatocellular carcinoma (HCC) cell } \\
\text { lines HepG2, OR6 and SN1a cells } \\
\text { The blood plasma samples of hepatocellular } \\
\text { carcinoma cells (HCC) patients and healthy } \\
\text { donors }\end{array}$ & $\begin{array}{l}\text { qRT-PCR analysis, and MTT } \\
\text { assay }\end{array}$ & $\begin{array}{l}\text { The miR-92a is highly expressed in hepatocellular carcinoma (HCC). } \\
\text { Thus, the expression level of miR-92a affects the proliferation of } \\
\text { hepatoma cell lines HepG2, OR6 and SN1a cells. Also, the ratio of miR- } \\
92 \mathrm{a} / \mathrm{miR}-638 \text { decreased in the plasma samples from the HCC patients } \\
\text { compared with healthy donors. }\end{array}$ & $\begin{array}{l}\text { (Shigoka et al. } \\
\text { 2010) }\end{array}$ \\
\hline $\mathrm{CD} 9$, and $\mathrm{CD} 63$ & $\begin{array}{l}\text { The human HCC cell lines SMMC-7721, } \\
\text { MHCC-97H, MHCC-97 L, and LO2 cells } \\
4 \text { to } 6 \text { week old male BALB/c nu/nu mice }\end{array}$ & $\begin{array}{l}\text { MTT assay, Enzyme-linked } \\
\text { immunosorbent assay } \\
\text { (ELISA), Electron microscopy } \\
\text { assay, Fluorescence- } \\
\text { activated cell sorting (FACS) } \\
\text { analysis, and Western } \\
\text { blotting }\end{array}$ & $\begin{array}{l}\text { The HCC cell-derived exosomes mediate sorafenib resistance in HCC } \\
\text { cells in vitro, and exosomes derived from highly invasive tumors have } \\
\text { grater effects than those derived from less invasive tumors. Also, HCC } \\
\text { cell-derived exosomes exerted their functions through enhancing the } \\
\text { level of proteins associated with sorafenib resistance, protecting } \\
\text { tumor cells from sorafenib-induced apoptosis and activating the } \\
\mathrm{HGF} / \mathrm{c}-\mathrm{Met} / \text { Akt signaling pathways in vitro. }\end{array}$ & (Qu et al. 2016b) \\
\hline $\begin{array}{l}\text { CD63, tumor susceptibility gene- } \\
101 \text { (TSG-101) }\end{array}$ & $\begin{array}{l}\text { Male Fischer-344 (F344) rats } \\
\text { N1S1 rat HCC cells (hepatocellular } \\
\text { carcinoma cells) } \\
\text { Blood plasma samples from the Lateral tail } \\
\text { vein of the Rat }\end{array}$ & $\begin{array}{l}\text { Electron microscopy assay, } \\
\text { and Western blotting }\end{array}$ & $\begin{array}{l}\text { The adipose-derived mesenchymal stem cells (ADMSCs) derived } \\
\text { exosomes enhanced natural killer T-cell (NKT) cell anti-tumor } \\
\text { response in rats, through facilitating HCC inhibition, early apparent } \\
\text { diffusion coefficient (ADC) increase, and low-grade tumor } \\
\text { differentiation. }\end{array}$ & (Ko et al. 2015) \\
\hline $\begin{array}{l}\text { ACTB, TUBA1A, FN1, FNLA, CD61, } \\
\text { HLA-A, LGALS3BP, Alix, RAB5B, } \\
\text { RAB5C, SDCBP, VPF37B, CLTC, } \\
\text { ARF1, ANXA2, ANXA5, HSC70, } \\
\text { HSP72, RAC1, STOM, MFGE8, MVP, } \\
\text { GNA12, PTGFRN, HBA1, tumor } \\
\text { susceptibility gene-101 (TSG-101), } \\
\text { and Grp94 }\end{array}$ & $\begin{array}{l}\text { The inhoused established human HCC cell } \\
\text { lines HKCI-C } 3 \text { and HKCI-8 cells } \\
\text { The hepatocellular carcinoma (HCC) cell line } \\
\text { MHCC } 97 \mathrm{~L} \text { cells } \\
\text { The immortalized hepatocyte cell line MIHA } \\
\text { cells }\end{array}$ & $\begin{array}{l}\text { qRT-PCR analysis, Ion } \\
\text { Torrent Next-Generation } \\
\text { Sequencing, and Western } \\
\text { blotting }\end{array}$ & $\begin{array}{l}\text { The internalization of exosomes could activate PI3K/AKT and MAPK } \\
\text { signaling pathway, and promoted secretion of MMP-2 and MMP-9 } \\
\text { that favored cell invasion. Also, by proteome analysis syndecan- } \\
\text { syntenin-ALIX is known to support biogenesis of exosomes and the } \\
\text { segregation of signaling cargo to these vesicles. The research also } \\
\text { detected the components of endosomal protein sorting complex, such } \\
\text { as VPS28 and VPS37, whose functions are required for exosome } \\
\text { cargo sorting Process. }\end{array}$ & (He et al. 2015) \\
\hline MiR-718, and MiR-1246 & $\begin{array}{l}\text { Six cases that underwent living donor liver } \\
\text { transplantation (LDLT) } \\
\text { Blood plasma samples from patients that } \\
\text { underwent living donor liver transplantation } \\
\text { (LDLT) } \\
\text { The hepatocellular carcinoma (HCC) cell } \\
\text { lines Huh-7, and PLC/PRF } / 5 \text { cells }\end{array}$ & $\begin{array}{l}\text { qRT-PCR analysis, Electron } \\
\text { microscopy assay, MTT } \\
\text { assay, MicroRNA microarray } \\
\text { analysis, and Western } \\
\text { blotting }\end{array}$ & $\begin{array}{l}\text { The specific biomarker miR-718 showed significantly different } \\
\text { expression in the serum exosomes of HCC cases with recurrence after } \\
\text { LT compared with those without recurrence. Decreased expression of } \\
\text { miR-718 was associated with HCC tumor aggressiveness in the } \\
\text { validated cohort series. }\end{array}$ & $\begin{array}{l}\text { (Sugimachi et al. } \\
\text { 2015) }\end{array}$ \\
\hline $\begin{array}{l}\text { MiR-21, CD63, and tumor } \\
\text { susceptibility gene-101 (TSG-101) }\end{array}$ & 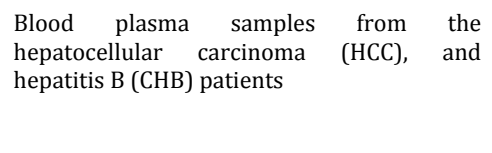 & $\begin{array}{l}\text { qRT-PCR analysis, Electron } \\
\text { microscopy assay, and } \\
\text { Western blotting }\end{array}$ & $\begin{array}{l}\text { The expression of serum exosomal miR- } 21 \text { was higher in patients } \\
\text { with HCC than in patients with CHB and healthy volunteers, the } \\
\text { sensitivity of detection is much lower than using exosomal miR- } 21 \text {. } \\
\text { These findings indicate that miR- } 21 \text { is enriched in serum exosomes } \\
\text { which provides increased sensitivity of detection than whole serum. }\end{array}$ & $\begin{array}{l}\text { (Wang et al. } \\
\text { 2014a) }\end{array}$ \\
\hline
\end{tabular}


HSP70, major histocompatibility complex (MHC) class I, polypeptiderelated sequence A (MICA) and MICB

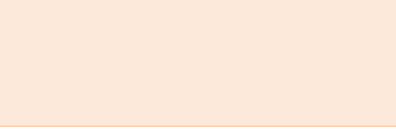

MiR-10b, MiR-21, MiR-122, and MiR-200a

Transactive response DNA-binding protein of $43 \mathrm{kDa}$ (TDP-43)

TrkB, P75 ${ }^{\text {NTR }}$, sortilin, HSP90, CD63, and $\mathrm{CD} 9$

$-$

MiR-9, CD44, CD45, CD105
Peripheral blood samples of hepatocellular carcinoma (HCC) patients

Peripheral blood mononuclear cells (PBMCs)

Peripheral blood NK cells

The hepatocellular carcinoma (HCC) cell lines HepG2 cells

The hepatocellular carcinoma (HCC) tissues and blood plasma samples of 108 male fisher 344 rats

The human glioma cell line U251 cells

Collection of cerebrospinal fluid (CSF) from glioblastoma patients and normal control (NC)-CSF

The human GBM cell line U87-MG cells

Two derived cell lines from U87-MG cells (human empty vector $\mathrm{pLKO}$, control cells and sh YKL-40 cells)

Female NOD/SCID mice

Blood plasma samples of glioblastoma patients

Luciferase expression mice glioblastoma cell ine GL26- Luc cells

C57BL/6j mice (H-2b) (6-8weeks, female)

The glioblastoma multiforme (GBM) tissue samples

The glioblastoma cell lines U87, T98G, BT145 (primary GBM), and BT164 (recurrent GBM) cells

The mesenchymal stem cells (MSCs)
qRT-PCR analysis, Electron microscopy assay, and Western blotting

MS-275 (one of the histone deacetylase inhibitor (HDACi) drugs) modified exosomes enhance the cytotoxic effect of NK cells HSP70.

(Xiao et al. 2013)

qRT-PCR analysis, Electron microscopy assay, Flow blotting The changing in the expression of both exosomes and miRNAs ( $\mathrm{miR}-$ $10 \mathrm{~b}, \mathrm{miR}-21, \mathrm{miR}-122$, and miR-200a) was observed during cirrhosis whit the early HCC stage. Therefore, the combination of circulatin miRNAs and exosomes might serve as promising biomarkers for virus infected HCC screening and cirrhosis discrimination.

Western blot analysis

The ALS-FTD-CSF incubation with U251 cells generate TDP-43 mislocalization, prion-like propagation of TDP-43 ageregates, and mislocalization, prion-like propagation of TDP-43 aggregates, and the exosome and TNTs-like structure. Thus, incubation of ALS-CSF and ALS-FTD-CSF with U51 causes toxic to the cells.

qRT-PCR analysis, Electron

microscopy assay, Flow

cytometry assay, and

Western blotting

The loss of aggressiveness in YKL-40-silenced cells significantly reduced TrkB, p75NTR and sortilin expression. Thus, the release of TrkB in exosomes from control glioma cells, was able to rescue both migration and activation of YKL-40-inactivated cells.

(Pinet et al. 2016)

Flow cytometry assay

The GL26 cells-derived exosomes significantly promote GL26 tumor growth in vivo. In fact the GL26 cells-derived exosomes, suppressed the cytotoxic activity of CD8+T cells both in vivo and in vitro, that leading to reduction of $C D 8+T$ cells in spleen and inhibition of cytolytic associated IFN- $\gamma$ and granzyme B.

qRT-PCR analysis, Flow cytometry assay, and Western blotting The promotion of miR-9 promotes temozolomide (TMZ)-resistant
GBM cells. To block miR-9, methods were developed with Cy5-tagged anti-miR-9. Dye-transfer studies indicated intracellular communication between GBM cells and MSCs. This occurred by gap junctional intercellular communication and the release of microvesicles. Thus, anti-miR-9 was transferred from MSCs to GBM cells.
(Liu et al. 2015)

(Ding et al. 2015)

(Liu et al. 2013)

(Munoz et al. 


\begin{tabular}{|c|c|c|c|c|}
\hline $\begin{array}{l}\text { CRYAB (crystallin, alpha B), CD9, } \\
\text { CD63 }\end{array}$ & The human glioma cell line U373 cells & $\begin{array}{l}\text { Enzyme-linked } \\
\text { immunosorbent assay } \\
\text { (ELISA), Electron microscopy } \\
\text { assay, and Western blotting }\end{array}$ & $\begin{array}{l}\text { Increase in CRYAB levels in GBM coupled with its secretion via } \\
\text { exosomes points to an important mode of intercellular } \\
\text { communication which, in GBM, may confer resistance to apoptosis in } \\
\text { surrounding cells following radiation and chemo-therapies. } \\
\text { Proinflammatory cytokines also bring about profound changes in the } \\
\text { proteome of the exosome. }\end{array}$ & $\begin{array}{c}\text { (Kore \& Abraham } \\
\text { 2014) }\end{array}$ \\
\hline CD11b, CD14, CD16, and CD163 & $\begin{array}{l}\text { The glioblastoma multiforme (GBM) tissue } \\
\text { samples } \\
\text { The human peripheral blood mononuclear } \\
\text { cells (PBMC) of GBM patients }\end{array}$ & $\begin{array}{l}\text { Enzyme-linked } \\
\text { immunosorbent assay } \\
\text { (ELISA), Flow cytometry } \\
\text { assay, and Luminex Analysis }\end{array}$ & $\begin{array}{l}\text { The M2-like monocytes expressing CD14+ and CD163+, another } \\
\text { indicator of Th2 bias, are promoted in GBM patient blood and } \\
\text { associated with high serum concentrations of colony } 2 \text { stimulating } \\
\text { factor } 2 \text { and } 3 \text {, as well as interleukin-2, -4, and }-13 \text {, the latter } 2 \\
\text { cytokines being hallmarks of Th2 immunity. Fractionation of GBM } \\
\text { patient sera into samples enriched for exosomes or soluble factors } \\
\text { proved that both fractions are capable of inducing CD163 expression } \\
\text { in normal monocytes. }\end{array}$ & $\begin{array}{c}\text { (Harshyne et al. } \\
\text { 2015b) }\end{array}$ \\
\hline Nanofilament & $\begin{array}{l}\text { The human glioblastoma cell lines U87 and } \\
\text { U251cells } \\
\text { The human melanoma cell line SKMEL cells } \\
\text { Normal human astrocytes (NHA) }\end{array}$ & $\begin{array}{l}\text { Piezoresponse force } \\
\text { microscopy (PFM) }\end{array}$ & $\begin{array}{l}\text { Compared with normal exosomes, glioblastoma exosomes displayed } \\
\text { numerous nanofilaments, and the nanofilaments were trypsin- and } \\
\text { RNase-resistant. Based on in vitro uptake assays, glioblastoma } \\
\text { exosomes indicated a significantly higher uptake in cells compared } \\
\text { with normal exosomes. }\end{array}$ & $\begin{array}{l}\text { (Sharma et al. } \\
\text { 2014) }\end{array}$ \\
\hline $\begin{array}{l}\text { Actin, CD9, CTGF, tumor } \\
\text { susceptibility gene } 101 \text { (TSG-101), } \\
\text { apoptosis-linked gene2-interacting } \\
\text { protein x (Alix), IGFBP2, phospho- } \\
\text { /total TrkA, phospho-/total FAK, } \\
\text { phospho-/total src, phospho-/total } \\
\text { Paxillin }\end{array}$ & $\begin{array}{l}\text { The glioblastoma multiforme (GBM) cell } \\
\text { lines LN18, U87MG, and U251cells } \\
\text { The GBM stem-like cell lines GBAM1, and } \\
\text { GBMJ1 cells } \\
\text { The Human umbilical vein endothelial cells } \\
\text { (HUVEC-CS) }\end{array}$ & $\begin{array}{l}\text { qRT-PCR analysis, Flow } \\
\text { cytometry assay, Electron } \\
\text { microscopy assay, and } \\
\text { Western blotting }\end{array}$ & $\begin{array}{l}\text { CTGF mRNA and IGFBP2 protein levels were elevated, and coculture } \\
\text { of nonirradiated cells with exosomes isolated from irradiated cells } \\
\text { increased CTGF protein expression in the recipient cells. Besides, } \\
\text { these exosomes promoted the activation of TrkA, FAK, Paxillin, and } \\
\text { Src in recipient cells, molecules involved in cell migration. }\end{array}$ & $\begin{array}{l}\text { (Arscott et al. } \\
\text { 2013) }\end{array}$ \\
\hline $\begin{array}{l}\text { CD63, CD71, CD81, and AS-ODN } \\
\text { (Antisense oligodeoxynucleotide) }\end{array}$ & $\begin{array}{l}\text { The human glioblastoma cell line U118 cells } \\
\text { Primary patient tumor cell lines } \\
\text { The human peripheral } \\
\text { blood mononuclear cells (PBMC) } \\
\text { Murine glioma cell line GL261 }\end{array}$ & $\begin{array}{l}\text { Flow cytometry assay, } \\
\text { Electron microscopy assay, } \\
\text { and Enzyme-linked } \\
\text { immunosorbent assay } \\
\text { (ELISA) }\end{array}$ & $\begin{array}{l}\text { The included AS-ODN releasing from the chambers is directed against } \\
\text { the insulin-like growth factor type-1 receptor, is immunostimulatory, } \\
\text { and therefore leading to promote presentation of these antigens. The } \\
\text { glioma-derived exosomes were detected to express CD63, CD71, and } \\
\text { CD81, endosomal antigens. }\end{array}$ & $\begin{array}{c}\text { (Harshyne et al. } \\
\text { 2015a) }\end{array}$ \\
\hline CD 9, CD63, and CD81 & $\begin{array}{l}\text { The brain neuronal glioblastoma- } \\
\text { astrocytoma cell line U-87 MG cells } \\
\text { The Immortalized mouse brain endothelial } \\
\text { cell line bEND.3 cells } \\
\text { The neuroectodermal tumor cell line PFSK-1 } \\
\text { cells } \\
\text { The glioblastoma cell line A-172 cells }\end{array}$ & $\begin{array}{l}\text { qRT-PCR analysis, Flow } \\
\text { cytometry assay, Electron } \\
\text { microscopy assay, Enzyme- } \\
\text { linked immunosorbent assay } \\
\text { (ELISA), and Western } \\
\text { blotting }\end{array}$ & $\begin{array}{l}\text { The exosomes released from brain endothelial cells delivered } \\
\text { anticancer drug across the blood-brain barrier (BBB), which } \\
\text { subsequently exerted cytotoxic efficacy against brain cancer. Also, the } \\
\text { high presence of CD } 63 \text { in bEND.3 exosomes indicates that these } \\
\text { exosome nanovesicles might be differently implicated in receptor- } \\
\text { mediated transport across the BBB. }\end{array}$ & (Yang et al. 2015) \\
\hline
\end{tabular}




\begin{tabular}{|c|c|c|c|c|}
\hline $\begin{array}{l}\text { collagen type VI alpha 1, putative } \\
\text { RNA-binding protein } 15 \mathrm{~B} \text { chain A, } \\
\text { substrate induced remodeling of the } \\
\text { active site regulates HTRA1, } \\
\text { coatomer protein complex-subunit } \\
\text { beta 2, myosin-heavy chain 1, } \\
\text { keratin-type I cytoskeletal 9, HSP90, } \\
\text { and CD63 }\end{array}$ & $\begin{array}{l}\text { The brain neuronal glioblastoma- } \\
\text { astrocytoma cell line U-87 MG cells }\end{array}$ & $\begin{array}{l}\text { Electron microscopy assay, } \\
\text { matrix-assisted laser } \\
\text { desorption ionization time- } \\
\text { of-flight mass spectrometry } \\
\text { (MALDI-TOF-MS) analysis, } \\
\text { and Western blotting }\end{array}$ & $\begin{array}{l}\text { Through the proteome analysis of U-87MG exosome the Hsp90 was } \\
\text { promoted in exosomes exposed to a low temperature compared with } \\
\text { exosomes incubated under normal conditions. Also, there was } \\
\text { detected an increase expression of calcium-dependent secretion } \\
\text { activator } 2 \text { isoform b, hCG1817425, armadillo repeat-containing } \\
\text { protein 4, and immunoglobulin heavy variable 5-a in low } \\
\text { temperature-exposed proteome. Besides, The proteins that were } \\
\text { reduced on the L.T. gel were collagen alpha-1(VI), DNA } \\
\text { topoisomerase I, titin, mitochondrial isoform 2, RNA-binding protein } \\
\text { 15B, phosphoserine aminotransferase isoform 2, and Chain A, } \\
\text { Substrate Induced Remodeling Of The Active Site Regulates HTRA1 } \\
\text { Activity. }\end{array}$ & (Chun et al. 2016) \\
\hline MiR-21, MiR-155, and CD163 & $\begin{array}{l}\text { The neuroblastoma primary tissue samples } \\
\text { The neuroblastoma (NBL) cell lines CHLA- } \\
255 \text {, LA-N-1, SK-N-BE(2), KNCR, and IMR-32 } \\
\text { cells } \\
\text { Female nu/nu mice ( } 5 \text { weeks of age) }\end{array}$ & $\begin{array}{l}\text { qRT-PCR analysis, Flow } \\
\text { cytometry assay, and } \\
\text { Luciferase reporter assay }\end{array}$ & $\begin{array}{l}\text { The result indicated a new exosomic miR-21/TLR8/NF-kB/exosomic } \\
\text { miR-155/TERF1 axis triggered regardless of M1- or M2- polarization, } \\
\text { but not in dendritic cells involved in resistance to chemotherapy in } \\
\text { NBL, and identifies exosomes within the TME as important molecular } \\
\text { targets to restore drug sensitivity. }\end{array}$ & $\begin{array}{c}\text { (Challagundla et } \\
\text { al. 2015) }\end{array}$ \\
\hline $\begin{array}{l}\text { Major histocompatibility complex II } \\
\text { (MHC II), Hsp90 and flotillin-1 }\end{array}$ & $\begin{array}{l}\text { The human neuroblastoma cell line SH-SY5Y } \\
\text { cells } \\
\text { The human melanoma cell line A375 cells }\end{array}$ & $\begin{array}{l}\text { Electron microscopy assay, } \\
\text { and Western blotting }\end{array}$ & $\begin{array}{l}\text { The SH-SY5Y neuroblastoma-derived exosomes comprised of MHC II, } \\
\text { Hsp90 and flotillin-1, whereas other cargo proteins or neuron } \\
\text { specific proteins, such as actin or tau, NeuN, Sv2, are not released. } \\
\text { Moreover, the results showed that, when applied extracellularly, } \\
\text { exosomes released from neuronal cells modulated differentiation of } \\
\text { melanoma cells. }\end{array}$ & (Park et al. 2015) \\
\hline
\end{tabular}

